\title{
CHEMICAL KINETICS AND INTERACTIONS INVOLVED IN HORSERADISH PEROXIDASE-MEDIATED OXIDATIVE POLYMERIZATION OF PHENOLIC COMPOUNDS
}

\author{
by \\ Wenjing Cheng \\ Bachelor of Engineering, Shandong University, 2009
}

\author{
Submitted to the Graduate Faculty of \\ Swanson School of Engineering in partial fulfillment \\ of the requirements for the degree of \\ Master of Science
}

University of Pittsburgh 


\section{UNIVERSITY OF PITTSBURGH \\ SWANSON SCHOOL OF ENGINEERING}

This thesis was presented

by

Wenjing Cheng

It was defended on

November 17, 2011

and approved by

Leonard W. Casson, Ph.D, Associate Professor, Civil and Environmental Engineering

Department

Jason Monnell, Ph.D, Research Assistant Professor, Civil and Environmental Engineering Department

Thesis Advisor: Willie F. Harper, Jr., Ph.D, Associate Professor, Civil and Environmental Engineering Department 
Copyright (C) by Wenjing Cheng

2011 


\section{CHEMICAL KINETICS AND INTERACTIONS INVOLVED IN HORSERADISH PEROXIDASE-MEDIATED OXIDATIVE POLYMERIZATION OF PHENOLIC COMPOUNDS}

Wenjing Cheng, M.S.

\section{University of Pittsburgh, 2011}

To address the growing need for removing the emerging endocrine disrupting compounds (EDCs), the enzyme-based oxidative coupling reaction is suggested as promising alternative in consideration of its generally high specificity and removal efficiency on treatment of waters containing estrogenic phenolic chemicals.

Various factors that affect the reaction rate of oxidative coupling (OXC) reaction of phenolic estrogens catalyzed by Horseradish Peroxidase (HRP) were evaluated in this study. Kinetic parameters were obtained for the removal of phenol as well as natural and synthetic estrogens estrone $\left(\mathrm{E}_{1}\right), 17 \beta$-estradiol $\left(\mathrm{E}_{2}\right)$, estriol $\left(\mathrm{E}_{3}\right)$, and $17 \alpha$-ethinylestradiol $\left(\mathrm{EE}_{2}\right)$. Molecular orbital theory and Autodock software were employed to analyze chemical properties and substrate binding characteristics. It is found that the reactions were first order with respect to phenolic concentration and reaction rate constants $\left(\mathrm{k}_{\mathrm{r}}\right)$ were determined for phenol, $\mathrm{E}_{3}, \mathrm{E}_{1}, \mathrm{E}_{2}$ and $\mathrm{EE}_{2}$ (in increasing order). It is also found that oxidative coupling was controlled by enzyme-substrate interactions, not diffusion. Docking simulations show that higher binding energy and shorter binding distance both promote more favorable kinetics. This research is the first to show that the OXC of phenolics is an entropy-driven and enthalpy-retarded process. 
TABLE OF CONTENTS

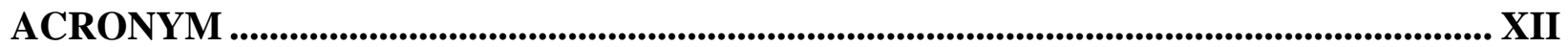

ACKNOWLEDGEMENT.................................................................................................. XIV

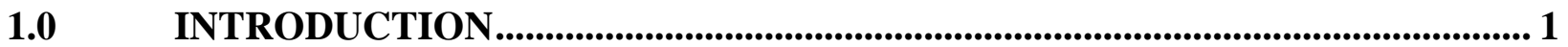

1.1 WASTEWATER TREATMENT AND ESTROGEN REMOVAL .................. 1

1.1.1.1 The Need for Estrogen Removal from Wastewater ............................... 1

1.1.1.2 Sources of Estrogens ...................................................................................... 1

1.1.1.3 Surface Water Studies .............................................................................. 5

1.1.2 Estrogen Removal During Activated Sludge Process ...................................... 7

1.1.2.1 Fate of Steroid Estrogens by Laboratory Studies .................................. 7

1.1.2.2 Assessment of Steroid Estrogen Removal in WWTPs......................... 8

1.1.3 Estrogen Removal with Advanced Wastewater Treatment alternatives. 9

1.1.3.1 Activated Carbon ............................................................................... 9

1.1.3.2 Advanced Oxidation ......................................................................... 10

1.1.3.3 Membrane Bioreactor.............................................................................. 10

1.2 ENZYME-MEDIATED OXIDATIVE COUPLING REACTION ............... 11

1.2.1 Introduction to enzymatic oxidative coupling reaction............................... 11

1.2.2 Horseradish Peroxidase......................................................................................... 14

1.3 ESTROGEN REMOVAL WITH OXIDATIVE COUPLING REACTION 17 
1.3.1 Feasibility of Removing Phenolics with HRP-OXC ............................... 17

1.3.2 Kinetic Study and Product Identification............................................ 18

1.3.3 Kinetics Determining Factors ......................................................... 21

1.3.4 Concerns on Oxidative Coupling Reaction............................................ 23

Critique of The Literature ..................................................................... 26

1.4 RESEARCH HYPOTHESIS AND OBJECTIVES .................................. 27

$\begin{array}{llllll}2.0 & \text { CHEMICAL KINETICS AND INTERACTIONS INVOLVED IN }\end{array}$ HORSERADISH PEROXIDASE MEDIATED OXIDATIVE POLYMERIZATION OF

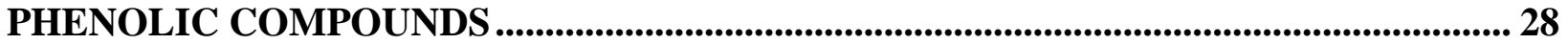

MATERIALS AND METHODOLOGY ...................................................... 28

2.1.1 Experimental Overview ...................................................................... 28

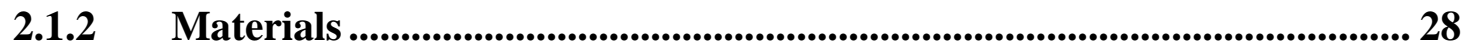

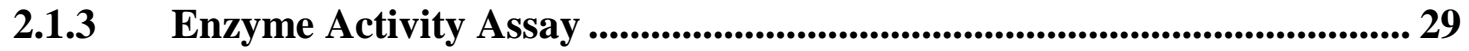

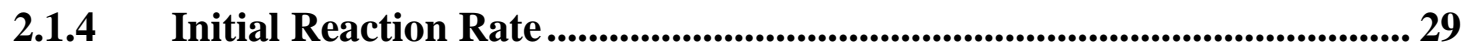

2.1.5 HRP-OXC on Real Wastewater .......................................................... 30

2.1.6 HPLC Analysis of Phenolic Substrates...................................................... 31

2.1.7 Kinetic and Thermodynamic Determination ......................................... 31

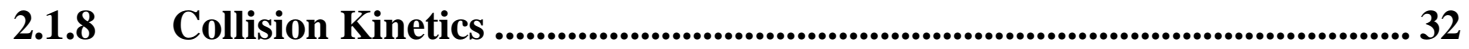

2.1.9 E $_{\text {номо }}$ Calculation................................................................................. 33

2.1.10 Docking Simulation........................................................................... 34

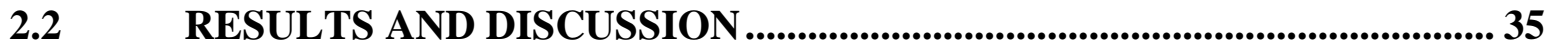

2.2.1 Reaction Kinetics of Estrogens ............................................................. 35

2.2.2 Molecular Volume and Substrate Binding ............................................ 39 
2.2.3 Thermodynamic Parameters ........................................................................... 41

2.2.4 HRP-OXC Applied on Real Wastewater ...................................................... 44

3.0 SUMMARY, CONCLUSIONS AND FUTURE WORK......................................... 46

3.1 SUMMARY AND CONCLUSIONS .................................................................. 46

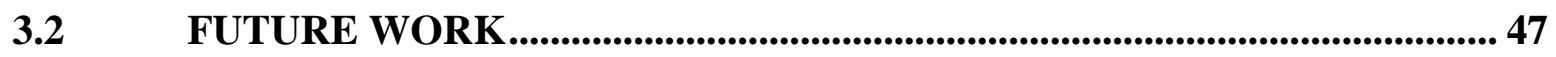

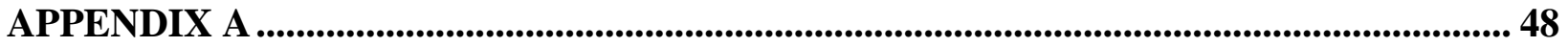

APPENDIX B

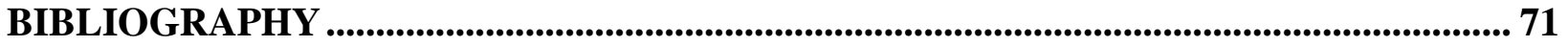




\section{LIST OF TABLES}

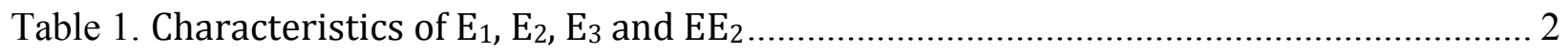

Table 2. Estimated total daily estrogen excretion of livetocks...................................................... 5

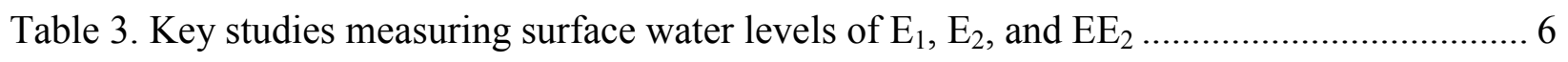

Table 4. Mean estrogen removal values with standard deviations ................................................ 8

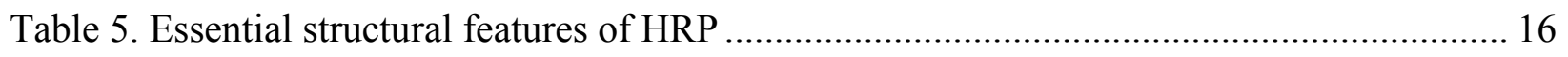

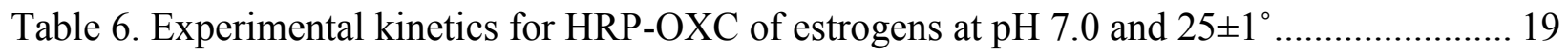

Table 7. Measured $\ln \left(\mathrm{k}_{\mathrm{cat}}\right)$ and $\mathrm{K}_{\mathrm{m}}$ values for 15 phenolics and simulated binding distances.... 20

Table 8. Measured rate constants and collision theory-based kinetics $\left(\mathrm{T}=25^{\circ} \mathrm{C}\right)$..................... 37

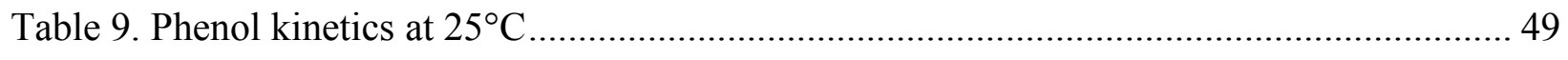

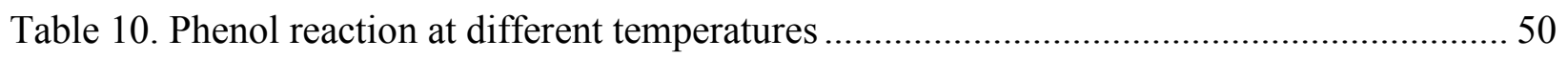

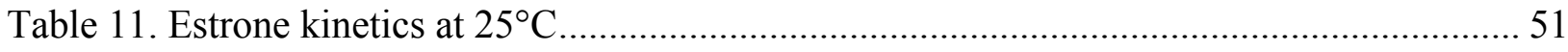

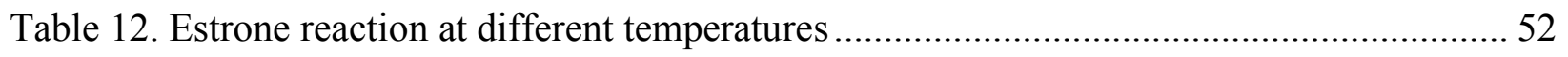

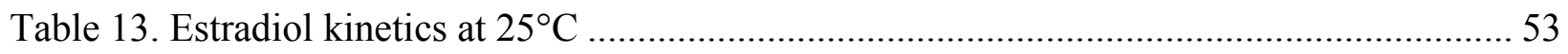

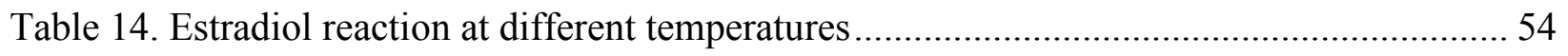

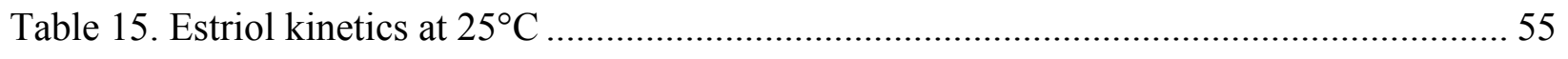

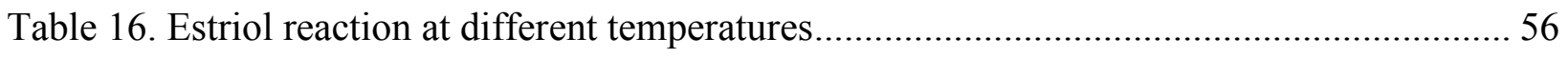

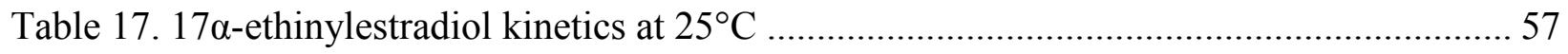


Table 18. 17 $\alpha$-ethinylestradiol reaction at different temperatures ......................................... 58

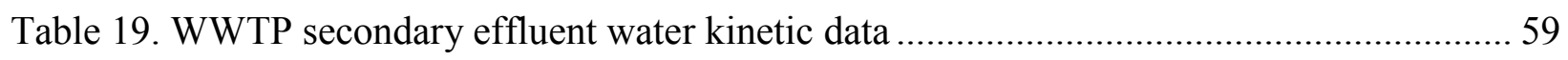

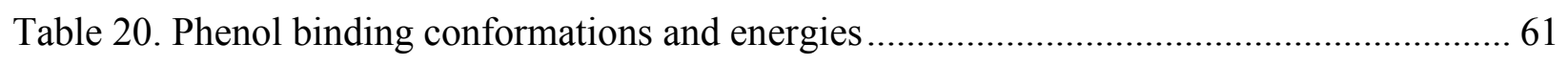

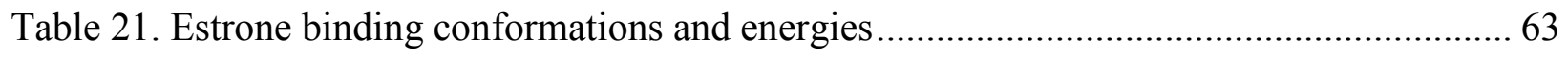

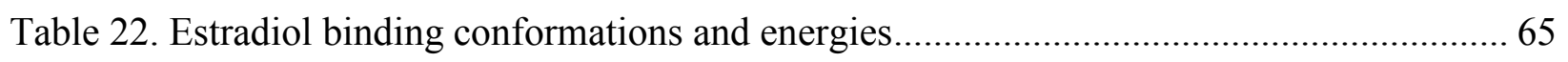

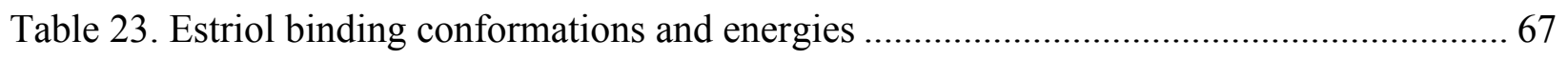

Table 24. 17 $\alpha$-ethinylestradiol binding Conformations and Energies .................................... 69 


\section{LIST OF FIGURES}

Figure 1. Relative estrogenic activity of some EDCs ................................................... 3

Figure 2. Points of estrogenic chemicals entry into water supply ........................................ 4

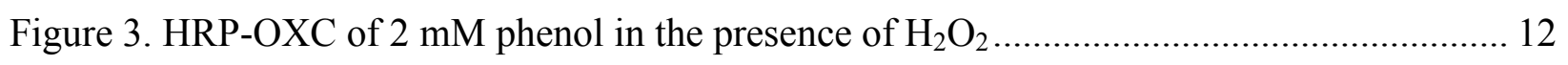

Figure 4. The catalytic cycle with HRP with aromatic compound ..................................... 13

Figure 5. Horseradish peroxidase isoenzyme C (Brookhaven accession code 1H5A)............... 15

Figure 6. Key amino acid residues in the HRP C active site ............................................. 15

Figure 7. Agilent 1200 series high-performance liquid chromatography (HPLC) .................... 31

Figure 8. Estrogen reaction rates with different initial estrogen concentration .......................... 36

Figure 9. Relationship between $\mathrm{k}_{\mathrm{r}}$ and $\mathrm{k}_{\mathrm{cat}}$ for studied estrogens ................................... 37

Figure 10. Relationship between $\mathrm{k}_{\mathrm{r}}$ and $\mathrm{E}_{\mathrm{HOMO}}$ for studies estrogens................................. 38

Figure 11. Relationship between $\mathrm{k}_{\mathrm{r}}$ and $\mathrm{K}_{\mathrm{m}}$ for studies estrogens .................................... 38

Figure 12. Molecular volume and binding properties from docking simulation ....................... 40

Figure 13. Docking simulation with Autodock 4.2 (example substrate: EE2) ......................... 40

Figure 14. Determinaton of thermodynamic parameters ................................................. 42

Figure 15. Linear relationship between activation enthalpy and activation entropy ................. 44

Figure 16. HRP-OXC applied on WWTP secondary effluent water .................................... 45

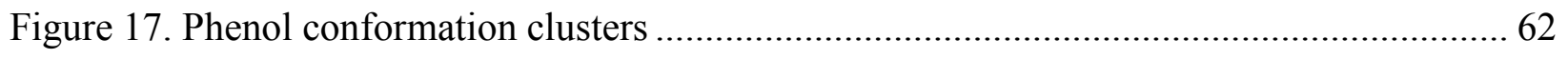


Figure 18. Interaction of phenol and relevent enzyme residues.

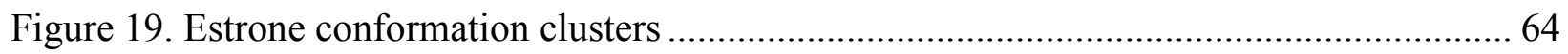

Figure 20. Interaction of estrone and relevent enzyme residues....................................... 64

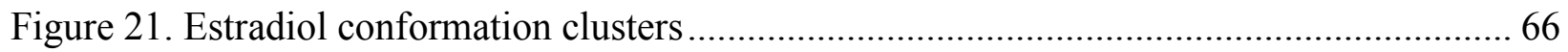

Figure 22. Interaction of estradiol and relevent enzyme residues. ..................................... 66

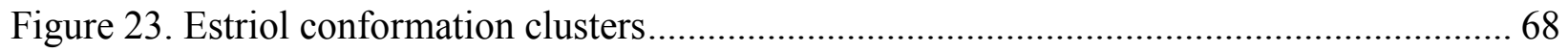

Figure 24. Interaction of estriol and relevent enzyme residues ........................................... 68

Figure $25.17 \alpha$-ethinylestradiol conformation clusters .................................................. 70

Figure 26. Interaction of $17 \alpha$-ethinylestradiol and relevent enzyme residues........................... 70 


\title{
ACRONYM
}

\author{
ACN - Acetonitrile \\ COD - Chemical oxygen demand \\ E1 - Estrone \\ E2 - 17ß-estradiol \\ E3 - Estriol
}

EDCs - Endocrine-disrupting compounds

EE2 - 17 $\alpha$-ethinylestradiol

$\mathrm{E}_{\mathrm{HOMO}}$ - Energy of the highest occupied molecular orbital

$E_{\text {LUMO }}$ - Energy of the lowest unoccupied molecular orbital

GAC - Granular activated carbon

HPLC - High performance liquid chromatography

HRP - Horseradish Peroxidase

HRP-OXC - Horseradish peroxidase catalyzed oxidative coupling reaction

LOD - Level of detection

MBR - Membrane Bioreactor

MV - Molecular volume

OXC - Oxidative Coupling

PAC - Powered Activated Carbon 
PEG - Polyethylene glycol

QSAR - Quantitative structure-activity relationships

$\mathrm{U} / \mathrm{ml}$ - Unit/ml

UF - ultrafiltration

UHF - Unrestricted Hartree-Fock

USEPA - U.S Environmental Protection Agency

WWTPs - wastewater treatment plants 


\section{ACKNOWLEDGEMENT}

I would like to acknowledge the following for their funding and support throughout my research:

- Dr. Willie F. Harper, Jr

- Dr. Leonard W. Casson

- Dr. Jason D. Monnell

- Dr. Amir Koubaa

- William Barr

- Zhongfeng Zuo

- Department of Civil and Environmental Engineering

- Family and Friends 


\section{INTRODUCTION}

\subsection{WASTEWATER TREATMENT AND ESTROGEN REMOVAL}

\subsubsection{The Need for Estrogen Removal from Wastewater}

Estrogenic compounds in the environment are causing concern due to a growing number of incidents reporting the feminized fish and organisms found in global waterway (Hogan et al., 2006; Iwaowicz et al., 2009; Jobling et al., 2006; Velicu, et al., 2009). These chemicals are frequently referred to as endocrine disrupting compounds (EDCs) based on their ability to mimic the natural estrogens found in humans and animals (Tyler et al., 2005; Purdom et al., 1994). Concentration as low as $0.1 \mathrm{ng} / \mathrm{l}$ could cause significant adverse reproduction effects (Aerni et al., 2004). Thus since 1996, the US Environmental Protection Agency's (USEPA) Office of Research and Development has considered endocrine disruption as one of its top six research priorities (USEPA, 2003). The USEPA aims to improve the removal of EDCs in a cost-effective manner.

\subsubsection{Sources of Estrogens}

Previous research has determined that natural steroid estrogens (e.g., estrone (E1), 17ßestradiol (E2), estriol (E3)) and synthetic steroid estrogen (17 $\alpha$-ethinylestradiol (EE2)) are the major contributors to the estrogenic activity observed in sewage effluents (Aerni et al., 2004; 
Leusch et al., 2005; Auriol et al., 2006b) in spite of their low concentrations (Gutendorf and Westendorf, 2001). As shown in Figure 1, which is compiled from Gutendorf and Weterdorf, 2001, with the same concentration, mammalian estrogens have much higher estrogenic potential than the other

Table 1. Characteristics of $E_{1}, E_{2}, E_{3}$ and $E_{2}$

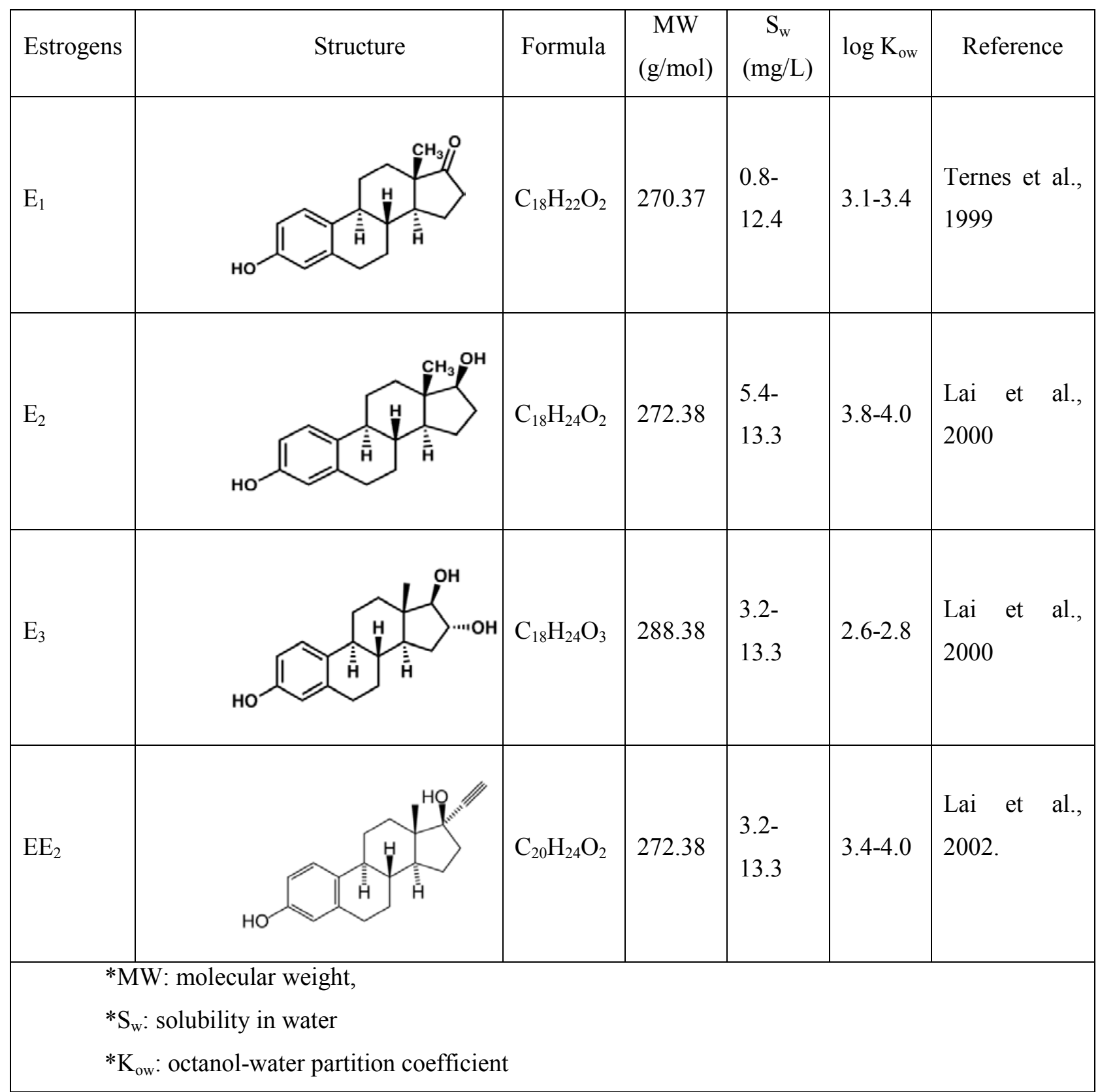


EDCs. The structures of the estrogens are shown in Table 1. These compounds have similar structure and there is a phenolic ring in all four estrogens.

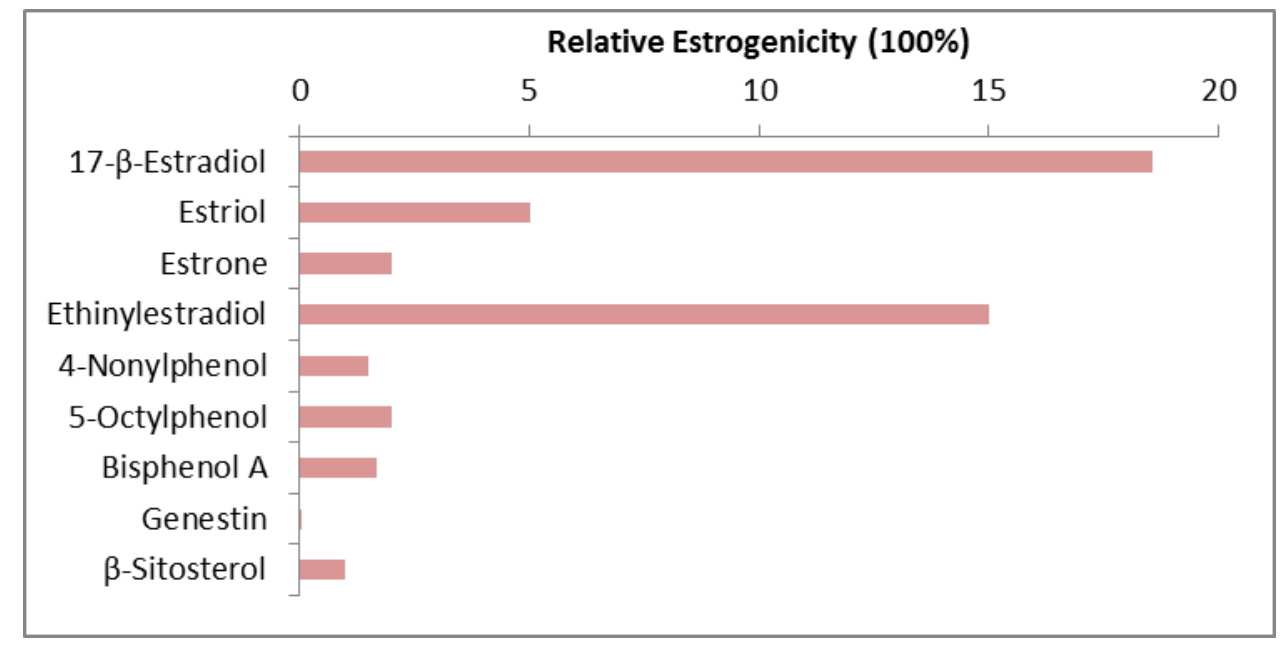

Figure 1. Relative estrogenic activity of some EDCs

These chemicals originate from agriculture, industry, humans, household products, and other pharmaceuticals. Figure 2. Which is adapted from Velicu et al., 2009, shows the various points of entry into waterways for estrogenic chemicals and human urine is recognized as the main source of natural and synthetic estrogens in the aquatic environment (Jobling et al., 2006).

\section{(1) Human estrogens}

Humans excrete natural estrogen $E_{1}, E_{2}$ and $E_{3}$ naturally. Pregnant woman can excrete as much as $6895 \mu \mathrm{g} /$ day of natural estrogen compared to $16.3 \mu \mathrm{g} /$ day with non-pregnant females (Johnson et al., 2000). In addition, natural and synthetic estrogens are also widely used in pharmaceuticals such as oral contraceptives, hormone replacement therapy, cancer therapy and veterinary medicine. These together contribute a considerable amount of EDCs to the environment. 


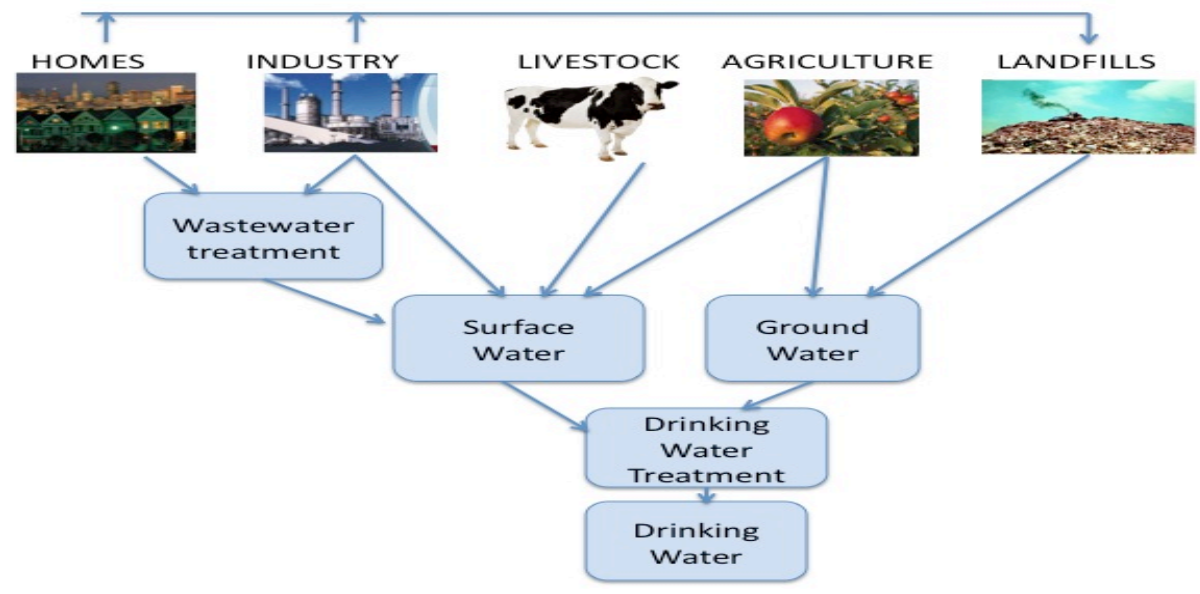

Figure 2. Points of estrogenic chemicals entry into water supply

\section{(2) Agricultural sources}

Livestock excrete the same natural estrogens $\left(\mathrm{E}_{1}, \mathrm{E}_{2}\right.$, and $\left.\mathrm{E}_{3}\right)$ as humans. In the US, 13fold more solid wastes are generated by livestock than human sanitary wastes (Burkholder et al., 2007). Table 2 shows the estrogen excretion quantity for several types of livestock. In addition to the naturally excreted hormones, livestock are also given prescribed hormones. These estrogens can enter the environment via the spreading use of agricultural fertilizer, rain-induced overflow, or leaching into the soils near manure storage facilities (Hanselman et al., 2003; Kolodziej et al., 2004).

\section{(3) Industrial Chemicals}

Industrial chemicals enter waterways through manufacturing facilities, domestic and industrial wastewater effluents, runoff from urban areas and leaching from landfills. The concentration varies based on the specific industry and with respect to different estrogens. 
Table 2. Estimated total daily estrogen excretion of livetocks

\begin{tabular}{|c|c|c|c|c|c|}
\hline \multirow[t]{2}{*}{ Species } & \multirow[t]{2}{*}{ Type } & total estrogens & total estrogens & \multirow{2}{*}{$\begin{array}{l}\text { total estrogens } \\
\text { excreted } \\
(\mu \mathrm{g} / \text { day })\end{array}$} & \multirow{2}{*}{$\begin{array}{l}\text { Million } \\
\text { heads (U.S.) }\end{array}$} \\
\hline & & $\begin{array}{l}\text { excreted in } \\
\text { urine }(\mu \mathrm{g} / \mathrm{day})\end{array}$ & $\begin{array}{l}\text { excreted in } \\
\text { feces }(\mu \mathrm{g} / \text { day })\end{array}$ & & \\
\hline & Calves & 15 & 30 & 45 & 17 \\
\hline & Cycling cows & 99 & 200 & 299 & 20 \\
\hline \multirow[t]{2}{*}{ Cattle } & Pregnant & $320-104,320$ & $256-7300$ & $576-111620$ & 43 \\
\hline & Cycling sow & 82 & 21 & 103 & \\
\hline \multirow[t]{2}{*}{ Pig } & Pregnant & $700-17,000$ & 61 & & \\
\hline & Cycling ewes & 3 & 20 & 23 & 2.5 \\
\hline sheep & Rams & 3 & 22 & 25 & 0.6 \\
\hline
\end{tabular}

Reference: Johnson et. al., 2000; Lange et al., 2002; National Agriculture Statistics Service

\subsubsection{Surface Water Studies}

$\mathrm{EE}_{2}$ and other natural estrogens can enter surface water through wastewater treatment effluent and runoff agricultural sources. Monitoring studies of surface water use a variety of $\mathrm{EE}_{2}$ detection methods find a range of values for $\mathrm{EE}_{2}$ and natural human and animal steroid estrogens. (Kuch et al., 2001; Filali-Meknassi et al., 2007). Table 3 summarizes key studies of surface water levels of $\mathrm{EE}_{2}$ and the natural steroid hormones $\mathrm{E}_{1}$ and $\mathrm{E}_{2}$. In general, total estrogen concentrations in the water sample are mostly above the safety concentration of $1 \mathrm{ng} / \mathrm{L}$ and thus may cause significant endocrine disruption to the ecosystem. 
Table 3. Key studies measuring surface water levels of $E_{1}, E_{2}$, and $E_{2}$

\begin{tabular}{|c|c|c|}
\hline Location & Study details & Conclusions \\
\hline $\begin{array}{l}\text { The } \\
\text { Netherlands } \\
\text { (Belfroid et } \\
\text { al., 1997) }\end{array}$ & $\begin{array}{l}11 \text { samples from costal } \\
\text { estuarine and freshwater } \\
\text { sources, LOD ranged } \\
\text { from } 0.1-0.6 \mathrm{ng} / \mathrm{L}\end{array}$ & $\begin{array}{l}E_{2} \text { found in } 3 \text { samples }(\text { mean }<\text { LOD) } \\
E_{2} \text { found in } 4 \text { samples }(\text { mean }<\text { LOD) } \\
E_{1} \text { found in } 7 \text { samples }(\text { mean concn }=0.3 \mathrm{ng} / \mathrm{L})\end{array}$ \\
\hline $\begin{array}{l}\text { UK } \\
\text { (William et } \\
\text { al., 2003) }\end{array}$ & $\begin{array}{l}28 \text { samples from } 2 \text { rivers, } \\
\text { LOD ranged from } 0.1 \\
\mathrm{ng} / \mathrm{L}-0.5 \mathrm{ng} / \mathrm{L}\end{array}$ & $\begin{array}{l}\mathrm{EE}_{2} \text { found in } 9 \text { samples (mean concn }=0.7 \mathrm{ng} / \mathrm{L} \text { ) } \\
\left.\mathrm{E}_{2} \text { found in } 9 \text { samples (mean concn }=0.9 \mathrm{ng} / \mathrm{L}\right) \\
\mathrm{E}_{1} \text { found in all samples (mean concn }=4.6 \mathrm{ng} / \mathrm{L} \text { ) }\end{array}$ \\
\hline $\begin{array}{l}\text { Germany } \\
\text { (Kuch and } \\
\text { Ballschmiter. } \\
\text { 2001) }\end{array}$ & $\begin{array}{l}31 \text { samples from surface } \\
\text { waters downstream of } \\
\text { sewage treatment plants, } \\
\mathrm{LOD}=200 \mathrm{pg} / \mathrm{L}\end{array}$ & $\begin{array}{l}E_{2} \text { found in } 15 \text { samples(Concn range: }<0.1-5.1 \\
n g / L) \\
E_{2} \text { found in } 14 \text { samples(Concn range: }<0.15-3.6 \\
n g / L) \\
E_{1} \text { found in } 29 \text { samples (Concn range: }<0.1-4.1 \\
n g / L) \\
\text { no detection of EE2 or E2 }\end{array}$ \\
\hline $\begin{array}{l}\text { Germany } \\
\text { (Ternes et } \\
\text { al., 1999) }\end{array}$ & $\begin{array}{l}15 \text { rivers, } \mathrm{LOD}=<0.5 \\
\mathrm{ng} / \mathrm{L}\end{array}$ & $\mathrm{E}_{1}$ found in 3 rivers (Concn range: $0.7-1.6 \mathrm{ng} / \mathrm{L}$ ) \\
\hline $\begin{array}{l}\text { United } \\
\text { States } \\
\text { (Benotti et } \\
\text { al., 2009) }\end{array}$ & $\begin{array}{l}19 \text { surface waters used as } \\
\text { drinking water sources } \\
\text { before treatment. Method } \\
\text { reporting limit was } \\
0.2 \mathrm{ng} / \mathrm{L} \text { for } \mathrm{E}_{1}, 0.5 \text { for } \\
\mathrm{EE}_{2} \text {, and } 1.0 \text { for } \mathrm{E}_{2}\end{array}$ & $\begin{array}{l}E_{2} \text { found in } 1 \text { sample }(1.4 \mathrm{ng} / \mathrm{L}) \\
\left.E_{1} \text { found in } 15 \text { samples (average }=0.3 \mathrm{ng} / \mathrm{L}\right) \\
E_{2} \text { found in } 1 \text { sample }(17 \mathrm{ng} / \mathrm{L})\end{array}$ \\
\hline
\end{tabular}




\subsubsection{Estrogen Removal During Activated Sludge Process}

Estrogen, or E1, E2, E3 and EE2 levels are higher in sewage influents than effluents, thus wastewater treatment plants (WWTPs) effectively remove a portion of both natural and synthetic hormones (Baronti et al., 2000). Batch microorganism studies have indicated that $\mathrm{E}_{1}$ and $\mathrm{EE}_{2}$ will not be eliminated in activated sludge over typical treatment times. Field data suggests that the activated sludge treatment process can consistently remove over $85 \%$ of $E_{2}, E_{3}$ and $\mathrm{EE}_{2}$ (Johnson and Sumpter, 2001).

\subsubsection{Fate of Steroid Estrogens by Laboratory Studies}

Estrogens are removed from wastewater aqueous phase by adsorption onto flocs and further degraded by microbes within the flocs. It is demonstrated that these compounds tend to adsorb strongly onto activated sludge. Much of the previous work has determined equilibrium partitioning coefficients $\left(\mathrm{k}_{\mathrm{d}}\right)$. Clara et al. 2004 found that the $\log \left(\mathrm{k}_{\mathrm{d}}\right)$ for steroid estrogens $\mathrm{E}_{2}$ and $\mathrm{EE}_{2}$ was 2.84 (2.64-2.97) and 2.84 (2.71-3.00), respectively. In the work by Ternes et al. 2004., the $\log \left(\mathrm{k}_{\mathrm{d}}\right)$ for $\mathrm{EE}_{2}$ was determined to be $2.54(2.49-2.58)(6)$. Yi et al. 2007 found that the $\log$ $\left(\mathrm{k}_{\mathrm{d}}\right)$ for $\mathrm{EE}_{2}$ was 2.7 for membrane bioreactor sludge and 2.3 when the sludge was taken from a sequencing batch reactor. Andersen et al. 2005 determined distribution coefficients $\left(\mathrm{k}_{\mathrm{d}}\right)$ with activated sludge biomass for the steroid estrogens $E_{1}, E_{2}$, and $E_{2}$ in batch experiments, and they determined $\log \left(\mathrm{k}_{\mathrm{d}}\right)$ values for those steroid estrogens of 2.6, 2.7, and 2.8, respectively. All of the results above suggest that the adsorption of estrogens to sludge plays critical role in the aqueous phase hormone removal. In the case of removal by biodegradation, Terns et al. 1999 witnessed little or no $\mathrm{EE}_{2}$ transformation over 20 hour s using an activated sludge batch test system. However, it is suggested that there is significant removal of natural estrogens in the case of 
nitrification, which is mainly attributed to two reasons. First, according to Vader et al., 2000, nitrifying sludges have shown to possess superior estrogen removing capacity and it was capable of degrading $\mathrm{EE}_{2}$ at a maximum rate of $1 \mu \mathrm{g} \mathrm{g}^{-1}$ sludge dry weight (DW) $\mathrm{h}^{-1}$ in the presence of $50 \mathrm{mg} \mathrm{NH}_{4}{ }^{+} \mathrm{g}^{-1} \mathrm{DW} \mathrm{h}{ }^{-1}$ while no degradation of $\mathrm{EE}_{2}$ was detected without nitrification; second, a nitrification process usually requires a longer sludge retention time (SRT) than a conventional activated sludge system. The laboratory data also suggest that some $\mathrm{EE}_{2}$ and $\mathrm{E}_{1}$ have poor removal efficiency in the activated sludge system (Johnson et al., 2001).

\subsubsection{Assessment of Steroid Estrogen Removal in WWTPs}

Baronti et al. 2000 a ssessed the $6 \mathrm{~W}$ WTPs around the city of Rome. The result is summarized in Table 4. In general, $87 \%$ of $E_{2}$ was removed and the result for $E_{1}, E_{2}$ and $E_{3}$ was $61 \%, 85 \%$ and $95 \%$, respectively. The results shows that the removal efficiency for $\mathrm{E}_{1}$ is much lower than the other estrogens.

Table 4. Mean estrogen removal values with standard deviations

\begin{tabular}{llll}
\hline WWTP & $\mathrm{E}_{2} \%$ removal & $\mathrm{EE}_{2} \%$ removal & $\mathrm{E}_{1} \%$ removal \\
\hline Cobis & $89( \pm 10, \mathrm{n}=5)$ & $87( \pm 15, \mathrm{n}=5)$ & $86( \pm 6, \mathrm{n}=5)$ \\
Fregene & $87( \pm 11, \mathrm{n}=5)$ & $84( \pm 19, \mathrm{n}=5)$ & $94( \pm 1, \mathrm{n}=1)$ \\
Ostia & $84( \pm 3, \mathrm{n}=5)$ & $84( \pm 18, \mathrm{n}=5)$ & $22( \pm 22, \mathrm{n}=5)$ \\
Roma Sud & $76( \pm 13, \mathrm{n}=5)$ & $83( \pm 15, \mathrm{n}=5)$ & $19( \pm 36, \mathrm{n}=5)$ \\
Roma Est & $92( \pm 2, \mathrm{n}=5)$ & $85( \pm 10, \mathrm{n}=5)$ & $84( \pm 8, \mathrm{n}=5)$ \\
Roma Nord & $92( \pm 3, \mathrm{n}=5)$ & $87( \pm 9, \mathrm{n}=5)$ & $65( \pm 33, \mathrm{n}=5)$ \\
Mean removal & $87( \pm 9, \mathrm{n}=30)$ & $85( \pm 14, \mathrm{n}=30)$ & $61( \pm 38, \mathrm{n}=30)$ \\
\hline
\end{tabular}

Reference: Baronti et al., 2000 


\subsubsection{Estrogen Removal with Advanced Wastewater Treatment alternatives}

As suggested by the discussions above, conventional wastewater treatment processes are not effective at completely eliminating all estrogens from wastewater. Activated carbon adsorption, ozonation or advanced oxidation, and membrane separation are considered as potential advanced treatment processes that are capable of removing many of the commonly found in wastewater (Ikehata et al., 2008; Snyder et al., 2007; Westerhoff et al., 2005 )

\subsubsection{Activated Carbon}

Granular Activated Carbon (GAC) is capable of removing estrogens through adsorption within short time (Synder, et al., 2007). However, the removal efficiency was determined to decrease as the initial estrogen concentration decreases. For example, when the initial concentration of E2 was decreased from 100 to $1 \mathrm{ng} / \mathrm{L}$, the removal efficiency decreased from $81 \%$ to $49 \%$ (Boyd et. al, 2003). Meanwhile, the presence of other soluble organics would compete with estrogen adsorption on to GAC. Fukuhara et al. 2005 found that the adsorption capacity for E2 was reduced by up to 200 fold magnitude in pure water compared to in river and secondary wastewater treatment effluent containing the same estrogen level. Thus the use of GAC is not a good option. Meanwhile, powered activated carbon (PAC) was shown to be more effective than GAC, especially with increased retention time (Westerhoff et al., 2005). However, the PAC-based system requires a continuous supply of media, which makes the application suitable only for temporary or seasonal use (Casey et al., 2003). 


\subsubsection{Advanced Oxidation}

The use of chemical oxidants has been reported highly efficient for estrogen removal from the aqueous phase in several bench-scale studies. For example, the time for oxidation of $\mathrm{E}_{2}$ into $\mathrm{E}_{1}$ was reduced from $48 \mathrm{~h}$ to $10 \mathrm{~min}$ and $2 \mathrm{~h}$, respectively, when ozone and chlorine were employed (Alum et al., 2004). An ozone dosage of $5 \mathrm{~m} \mathrm{~g} / \mathrm{L}$ successfully reduced the initial concentration of $3.0 \mathrm{ng} / \mathrm{L} \mathrm{E}_{2}$ and $13 \mathrm{ng} / \mathrm{L}$ of $\mathrm{E}_{1}$ to below detection limits of $1 \mathrm{ng} / \mathrm{L}$ (Westerhoff et al., 2005). Photodegradation of estrogens with UV lamps is another option. The degradation of estrogens at the initial concentration of $3-20 \mathrm{mg} / \mathrm{L}$ followed first-order kinetics and it has the optimum removal efficiency when the $\mathrm{pH}$ is around neutral (Liu et al., 2004).

Although these advanced oxidation options present improved removal efficiency with much shorter time than the biological approach, all of them are energy intensive, which limit their large-scale application in the wastewater treatment plants. Meanwhile, both biodegradation and advanced oxidation by-products have unknown estrogenic activity that may cause greater toxic effect to both human and ecosystem and it is at risk to simply oxidize these estrogens (Moriyama et al., 2004).

\subsubsection{Membrane Bioreactor}

Membrane Bioreactor (MBR) are able to maintain an extremely long SRT and diverse microbial community, facilitating the degradation of estrogen compounds (Wintgens et al., 2002). The removal of estrogens in MBR was achieved by sorption onto suspended and colloidal particles and biological degradation. Liu et al. 2005 reported a removal efficiency of over $82 \%$ for estrogens $\left(E_{2}, E_{1}\right.$ and $\left.E_{2}\right)$ with cross-flow ultrafiltration (UF) membranes. Wintgens et al. 2002 observed 28\% more estrogen removal than a GAC system in Nanopore MBR system. However, these MBR are subjected to serious fouling problem in treating effluent wastewater. 
Excess aeration to membrane surface is common for controlling membrane fouling in a submerged MBR system, but significant energy is consumed for excess air production (Kim et al., 2008).

\subsection{ENZYME-MEDIATED OXIDATIVE COUPLING REACTION}

\subsubsection{Introduction to enzymatic oxidative coupling reaction}

An enzymatic oxidative coupling $(\mathrm{OXC})$ reaction for removing estrogenic compounds is based on the fact that hydroxylated aromatic compounds can undergo extensive oxidative coupling and eventually polymerization in natural systems via reactions catalyzed by naturallyoccurring extracellular enzymes such as horseradish peroxidase (HRP). Oxidative coupling is fast and produces insoluble polymers that can be removed by sedimentation or filtration. Figure 3 shows the reaction of Horseradish Peroxidase catalyzed oxidative coupling reaction of $2 \mathrm{mM}$ phenol in the presence of hydrogen peroxide $(2 \mathrm{mM})$. Massive brown polymer precipitates formed only after 30 minutes of the reaction. OXC is not as energy intensive as other advanced oxidation processes (i.e. ozonation), and compared to microbial degradation, HRP-OXC is faster and does not present concerns about metabolite toxicity because the byproducts are not soluble. What is more, HRP-OXC can operate over a wide range of $\mathrm{pH}$ values, temperatures, and ionic strengths (Cabana et al., 2007). HRP-OXC now stands as a promising and potentially sustainable option for addressing the presence of endocrine disruptors and other phenolic chemicals in water. 


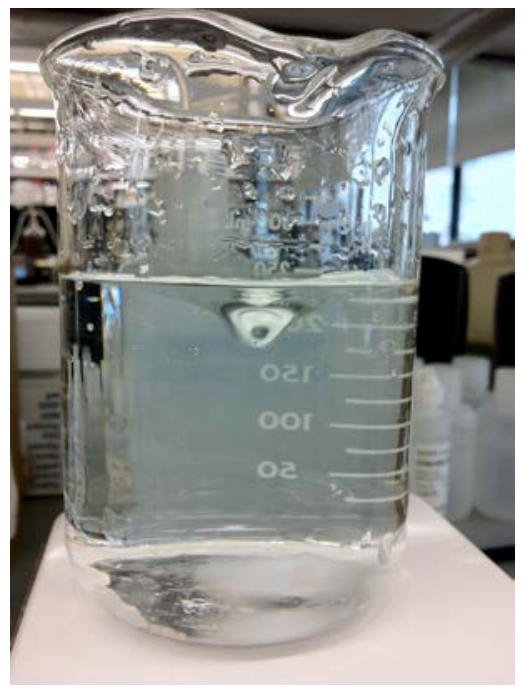

Reaction: 0 min

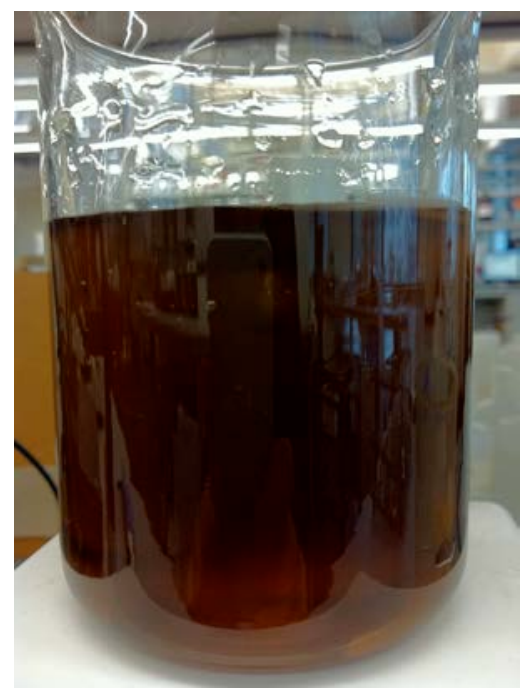

Reaction: 30min

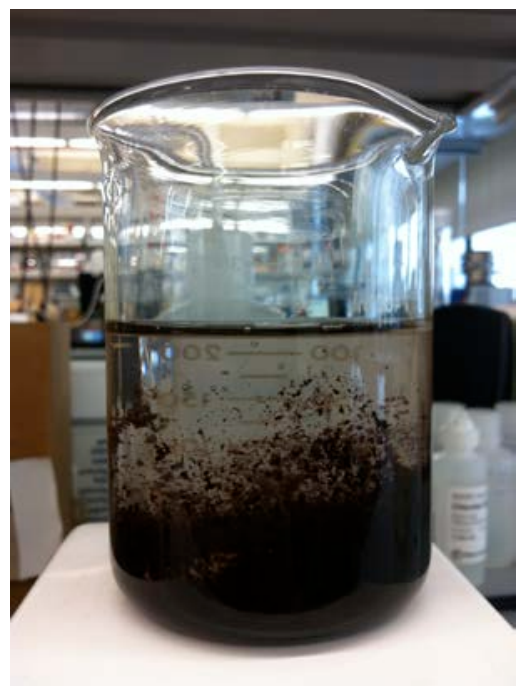

Settle for another $10 \mathrm{~min}$

Figure 3. HRP-OXC of $2 \mathrm{mM}$ phenol in the presence of $\mathrm{H}_{2} \mathrm{O}_{2}$

The mechanism of catalysis of horseradish peroxidase has been investigated extensively (Dunford et al., 1991, 1999; Veitch and Smith, 2001). Some important features of the catalytic cycle are illustrated in Figure 4. The first step involves a hydrogen peroxide-induced transfer of two electrons from the iron (III) resting state present at the active site of HRP to generate compound I, a high oxidation state intermediate featuring by a Fe (IV) oxoferryl center and a porphyrin-based cation radical. In the second step, a phenolic substrate donates an electron to the HRP iron (IV) ${ }^{+}$residue and generate HRP compound II, a Fe (IV) oxoferryl species that is one oxidizing equivalent above the resting state. Both compound I and compound II are strong oxidants and the second one-electron reduction step in which a phenolic substrate donates an electron to the HRP iron (IV) returns compound II to the resting state. This step has been proved to be the rate limiting step (Chang et al., 1993). Finally, two phenoxy radicals couple together to form dimers. These reaction products may in turn go on to participate in further coupling cycles, yielding higher order oligomer products with much smaller solubility. 


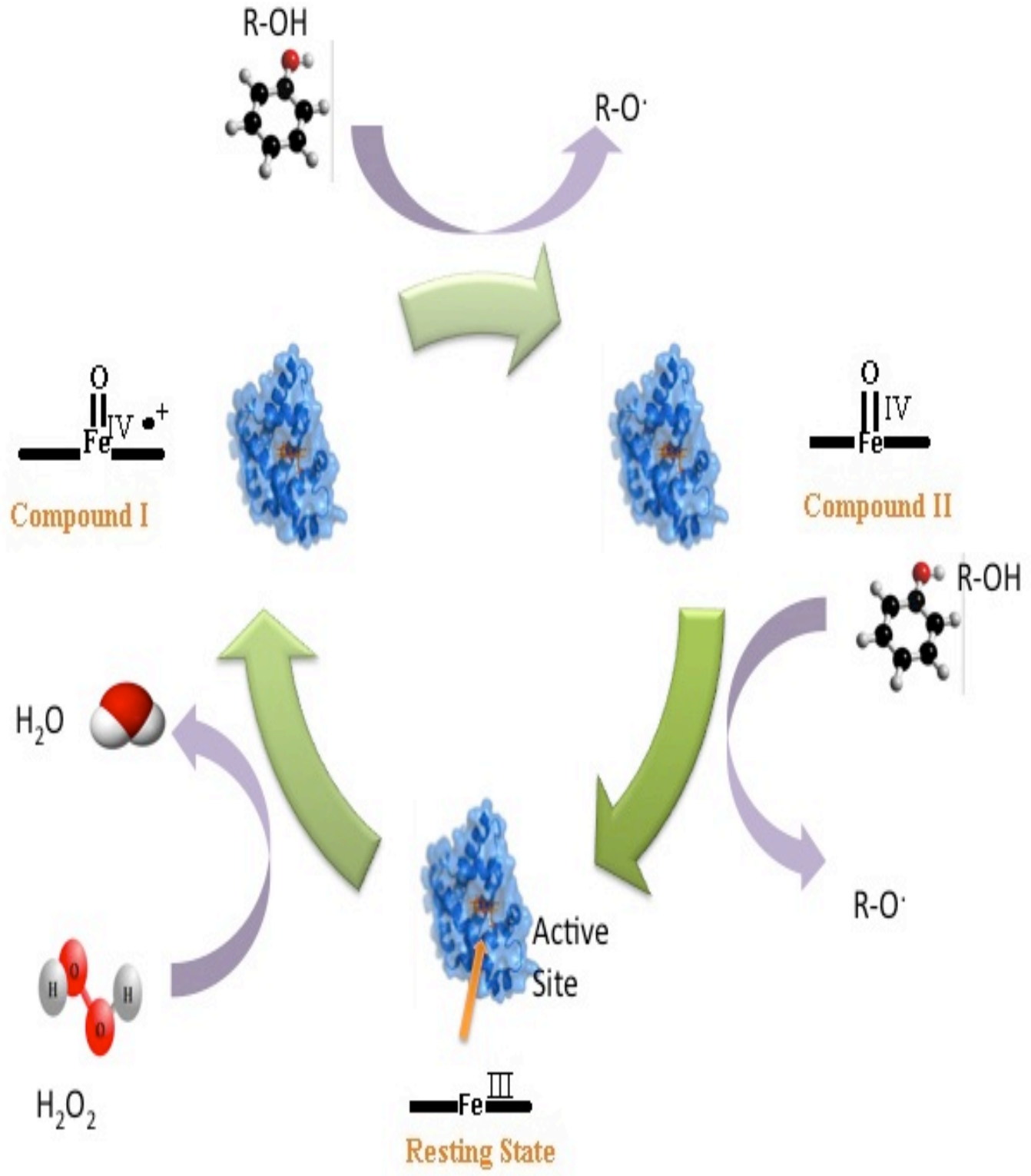

Figure 4. The catalytic cycle with HRP with aromatic compound 


\subsubsection{Horseradish Peroxidase}

The horseradish peroxidase (HRP) is a h eme-containing enzyme originated from the horseradish roots and utilizes hydrogen peroxide to oxidize a wide variety of organic and inorganic compounds. Production of HRP occurs on a relatively large scale because of the commercial uses of the enzyme.

HRP (Type C) contains two different types of metal center, Fe (III) protoporphyrin IX (usually referred to as the 'heme group') and two calcium atoms (Figure 5). Both are essential for the structural and functional integrity of the enzyme. The heme group is attached to the enzyme at His 170 (the proximal histidine residue) by a coordinate bond between the histidine side-chain and the heme iron atom as shown by Figure 6 . The second axial coordination site (on the so-called distal side of the heme plane) is unoccupied in the resting state of the enzyme but available to hydrogen peroxide during enzyme turnover. Figure 6, which is generated from Autodock 4.2 (Michel F. Sanner, 1999; Michel F. Sanner et al., 2002), shows the key amino acid residues in the heme-binding region of HRP C. His 170 , the proximal histidine residue, is coordinated to the heme ion atom whereas the corresponding distal coordination site above the plane of the heme is vacant. Small molecules such as carbon monoxide, cyanide, fluoride and azide bind to the heme iron atom at this distal side gives six-coordinate peroxidase complexes. Some bind only in their protonated forms, which are stabilized through hydrogen bonded interactions with the distal heme pocket amino acid side-chains of Arg 38 (the distal arginine) and His 42 (the distal histidine). Some essential structures and key residue functions are listed in Table 5. 


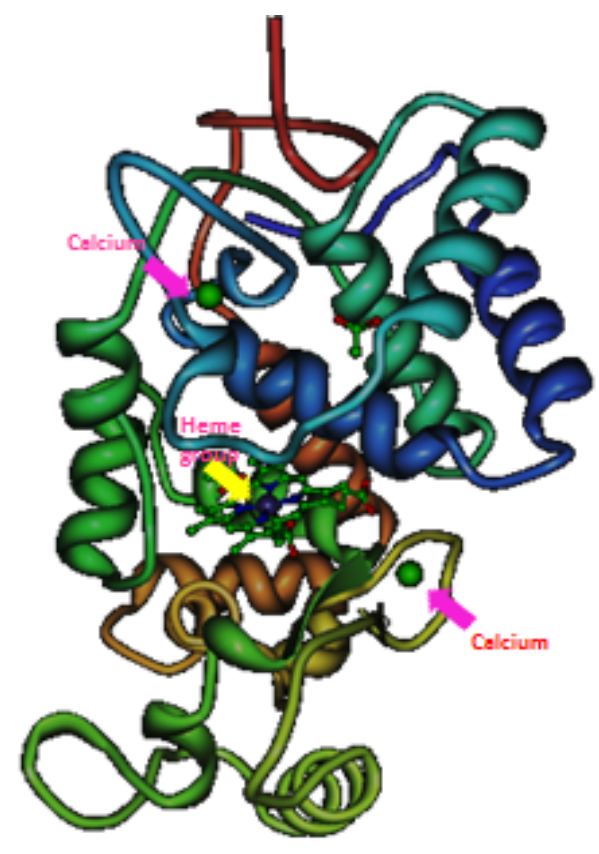

Figure 5. Horseradish peroxidase isoenzyme C (Brookhaven accession code 1H5A)

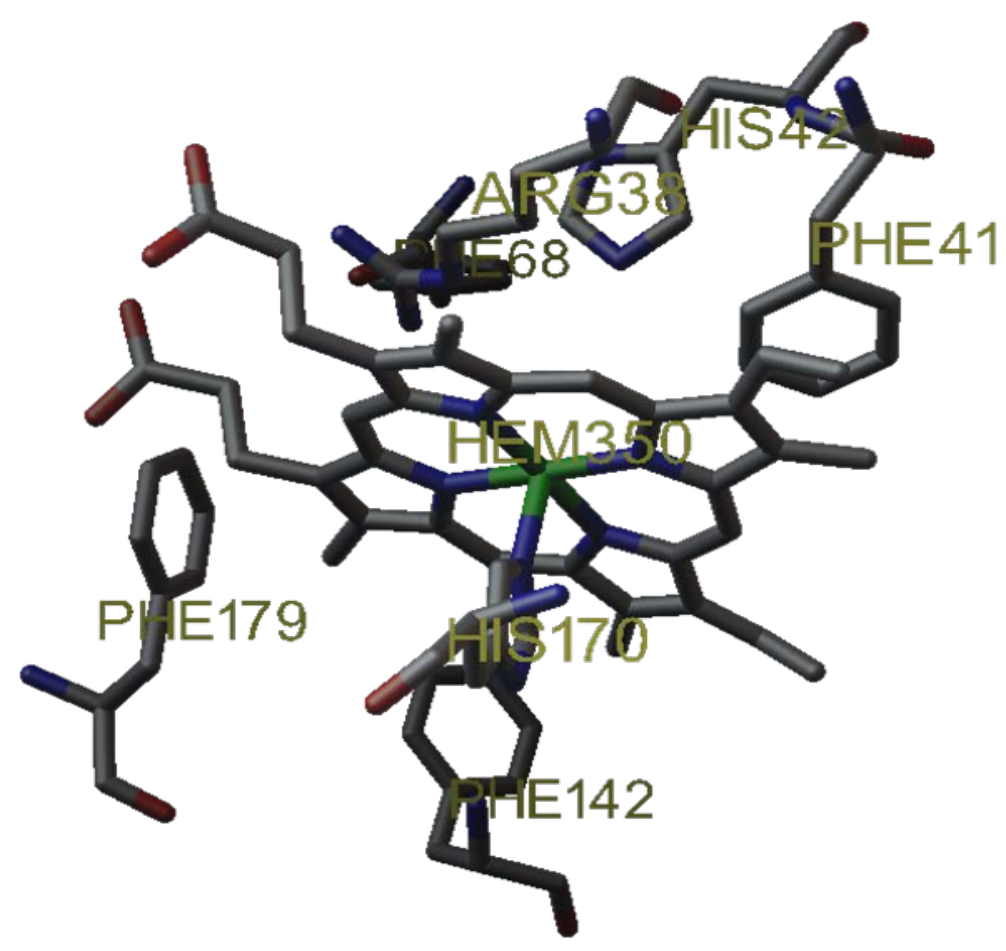

Figure 6. Key amino acid residues in the HRP C active site 


\section{Table 5. Essential structural features of HRP}

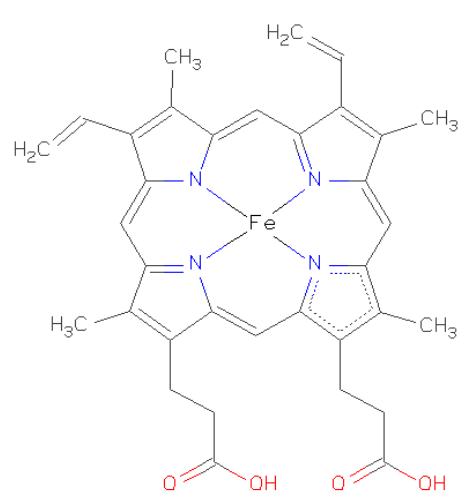

1. His170 forms coordinate bond to heme iron atom.

2. Asp247 carboxylate side-chain helps to control imidazolate character of His 170 ring.

3. His 170A1a mutant undergoes heme degradation when $\mathrm{H} 2 \mathrm{O} 2$ added and compound I and II are not detected; Imidazoles can bind to heme iron in the artificially created cavity but full catalytic activity is not restored because the His170A1a-imidazole complex does not maintain a fivecoordinate state (His42 also binds to $\mathrm{Fe}$ )

4. Aromatic substrates are oxidized at the exposed heme edge but do not bind to heme iron.

Calcium

\section{$\mathrm{Ca}$}

Distal 0-donors

Asp43, Asp50, Ser52 (side chain)

Asp43, Val46, Gly48 (carbonyl)

1 structural water

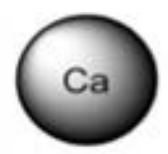

Proximal 0-donors

Thr171, Asp222, Thr225, Asp230 (side chain) Thr171, Thr225, Ile228 (carbonyl)
1. Distal and proximal $\mathrm{Ca} 2+$ ions are both seven-coordinate.

2. On calcium loss enzyme activity decreases by $40 \%$.

3. Structural water of distal CA site hydrogen banded to Glu64 which is itself hydrogen bonded to Asn70 and thus connects to the distal home pocket.

Arg38: Essential roles in (1), the formation and stabilization of compound I, (2) binding and stabilization of ligands and aromatics substrates (e.g. benzhydroxamic acid, phenol, estrogens, etc.)

Phe41: Prevents substrate access to the ferryl oxygen of compound I.

His42: Essential roles in (1), compound I formation (accepts proton from H202), (2) binding and stabilization of ligands and aromatic substrates.

Asn70: Maintains basicity of His42 side-chain through Asn70-His42 couple (Hydrogen bond from Asn70 amide oxygen to His42 imidazole $\mathrm{NH}$ )

Pro139: Part of a structural motif, '-Pro139-Ala140-Pro141' in HRP C, which is conserved in plant peroxidase.

Reference: Veitch and Smith, 2001, 


\subsection{ESTROGEN REMOVAL WITH OXIDATIVE COUPLING REACTION}

\subsubsection{Feasibility of Removing Phenolics with HRP-OXC}

The feasibility of removing phenolic compounds from wastewater by HRP catalyzed oxidative coupling reaction has been extensively investigated. The results of these experiments show promising removal efficiency over a wide range of phenolic compounds.

Yu et al. 1994 studied HPR-catalyzed phenol removal from water. Over a reaction time of 60 minutes, 5 dimeric and and 1 trimeric products were detected in the aqueous solution. More than $95 \%$ of phenol was removed from an initial phenol concentration of $188 \mathrm{mg} / \mathrm{L}$, the final concentration of dimers were each below $1 \mathrm{mg} / \mathrm{L}$. About $7 \%$ of the precipitate mass was attributed to the dimers and the rest consisted mainly of the compounds of higher hydrophobicity and molecular mass.

Huang et al. 2005 further investigated the effects of solution $\mathrm{pH}$ and background ion types and concentrations on the precipitation of polymeric products generated in the catalytically facilitated oxidative coupling of phenol. Phenol conversion was stable and efficient under different ionic strength or $\mathrm{pH}$ values. However, the product distribution between dissolved and precipitated forms was affected in a certain range, higher ionic strength and lower $\mathrm{pH}$ will promote the product precipitation. Their results on the prefered $\mathrm{PH}$ and ionic strength will assist feasibility assessments and process optimization with respect to engineering applications of catalyzed oxidative coupling reactions for wastewater treatment and soil decontamination. 
Huang et al. 2005 also looked into the feasibility of bisphenol A (BPA) removal from aqueous phase via oxidative coupling mediated by HRP. In their experiment, $150 \mu \mathrm{M}$ of BPA was almost completely transformed within $1 \mathrm{~min}$ in the presence of $150 \mu \mathrm{M} \mathrm{H}_{2} \mathrm{O}_{2}$ and $2.5 \mathrm{U} / \mathrm{ml}$ HRP. Meanwhile, more than $90 \%$ of BPA was converted to solid phase. The efficacy of the reaction at low substrate concentrations suggests the promising potential for HRP catalyzed reaction be used as an efficient means for removal of estrogenic phenolic compounds from waters and wastewaters.

Auriol et al. 2006 specifically applied the reaction to remove estrogens-namely $\mathrm{E}_{1}, \mathrm{E}_{2}, \mathrm{E}_{3}$ and $\mathrm{EE}_{2}$. They claimed that the HRP enzyme catalyzed process was capable of achieving $92 \%$ $100 \%$ removal of $E_{1}, E_{2}, E_{3}$ and $E_{2}$ with an initial concentration of $400 \mathrm{nM}$ for each within $1 \mathrm{~h}$ of treatment in the presence of $0.017 \mathrm{unit} / \mathrm{ml}(\mathrm{U} / \mathrm{ml}) \mathrm{HRP}$ in a synthetic solution at $\mathrm{pH} 7$ and $25 \pm 1{ }^{\circ} \mathrm{C}$. The optimal $\mathrm{pH}$ was observed to be near neutral conditions, which is applicable for common wastewater. This study proved that the HRP-catalyzed system is technically feasible for the removal of the main estrogens present in the environment at low concentrations.

\subsubsection{Kinetic Study and Product Identification}

Although HRP catalyzed oxidative coupling is fast compared to biological approach, the enzyme catalytic rate constant $\left(\mathrm{k}_{\text {cat }}\right)$ and the specificity $\left(\mathrm{K}_{\mathrm{m}}\right)$ varies significantly among substrates and with respect to different researchers. Researchers have investigated into the reaction kinetics and some of them tried to build a kinetic model so that they can get a sense for better predicting the removal trend. 
Yu et al.1994 proposed a two-substrate model with respect to the concentration of phenolics and HRP and claimed that phenol conversion behaves as a first-order reaction with respect to phenol concentration. Based on his work, the second order reaction rate constant for phenol is $\mathrm{K}_{\mathrm{pH}}=1.75^{*} 10^{5} \mathrm{M}^{-1} \mathrm{~min}^{-1}$ in the presence of $2 \mathrm{mM}$ initial $\mathrm{H}_{2} \mathrm{O}_{2}$ concentration. Auriol et al. 2007 tested both reaction order and the reaction rate constant of $E_{1}, E_{2}, E_{3}$ and $E_{2}$. They also obtain the Michaelis constant $\left(\mathrm{K}_{\mathrm{m}}\right)$ and maximum reaction velocity $\left(\mathrm{V}_{\max }\right)$ value when fitting the reaction kinetics in Michaelis-Menten model. The results are shown in Table 6, which shows that these estrogen reacts in the decreasing order of E2, E3, EE2 and E1.

Colosi et al. 2006 tested the reaction Michaelis-Menten model parameter value for 15 phenolics and the values are listed in Table 7. A comparison of these results with the conclusion of Auriol et al. 2007 shows inconsistency in both the reaction rate potential $\left(\mathrm{k}_{\mathrm{cat}}\right)$ and the partitioning coefficient $\left(\mathrm{K}_{\mathrm{m}}\right)$. For example, Colosi et al. 2006 got a higher $\mathrm{Km}$ value for EE2 than E2 while Auriol et al. 2007 concluded the opposite. Meanwhile, the reaction potential for E2 was 5 times as big as that for EE2 in Colosi et al. 2006 while they are similar value according to Auriol et al. 2007.

Table 6. Experimental kinetics for HRP-OXC of estrogens at $\mathrm{pH} 7.0$ and $25 \pm 1^{\circ}$

\begin{tabular}{ccccc}
\hline & Reaction order (n) & $\begin{array}{c}\text { Reaction rate constant } \\
\left(\mathrm{k}_{\mathrm{r}}\right)\left(\mathrm{M}^{-1} \mathrm{~s}^{-1}\right)\end{array}$ & \multicolumn{2}{c}{ Mechaelis-Menten model } \\
\cline { 4 - 5 } & 1.1357 & $1.56^{*} 10^{6}$ & $\mathrm{~K}_{\mathrm{m}}(\mathrm{uM})$ & $\mathrm{V}_{\mathrm{MAx}}\left(\mu \mathrm{g} \mathrm{l}^{-1} \mathrm{~s}^{-1}\right)$ \\
\hline $\mathrm{E}_{1}$ & 0.9000 & $2.80 * 10^{6}$ & 1.47 & 20.08 \\
$\mathrm{E}_{2}$ & 0.9929 & $2.40 * 10^{6}$ & 5.25 & 3.19 \\
$\mathrm{E}_{3}$ & 0.9267 & $1.90 * 10^{6}$ & 1.32 & 13.00 \\
$\mathrm{EE}_{2}$ & & & & 2.28 \\
\hline
\end{tabular}


Table 7. Measured $\ln \left(k_{\mathrm{cat}}\right)$ and $\mathrm{K}_{\mathrm{m}}$ values for 15 phenolics and simulated binding distances

\begin{tabular}{cccc}
\hline Compound & \multicolumn{2}{c}{ Measured parameters } & Simulation-estimated distance $(\AA)$ \\
\cline { 2 - 4 } & $\mathrm{Km}(\mu \mathrm{M})$ & $\ln \left(\mathrm{k}_{\mathrm{cat}}\right)\left(\mathrm{S}^{-1}\right)$ & Compound II H-His42 \\
\hline Phenol & 614.0 & 6.71 & 7.40 \\
1, 4-benzenediol & 91.8 & 8.19 & 8.63 \\
4-chlorophenol & 120.3 & 7.94 & 7.50 \\
4-nitrophenol & 73.7 & 6.46 & 7.22 \\
4-methoxyphenol & 307.9 & 9.59 & 8.54 \\
4-ethylphenol & 273.1 & 9.09 & 7.35 \\
4-ethoxyphenol & 204.4 & 9.73 & 7.52 \\
2, 6-dimethoxyphenol & 1188.0 & 9.51 & 7.46 \\
4-tert-butylphenol & 157.6 & 6.98 & 7.73 \\
4-phenylphenol & 25.8 & 7.21 & 9.05 \\
Bisphenol A & 3.5 & 9.99 & 10.15 \\
4-octylphenol & 6.0 & 5.18 & 7.71 \\
17ß-estradiol & 12.9 & 5.22 & 10.78 \\
17a-ethynylestradiol & 2.6 & 6.24 & 12.40 \\
\hline
\end{tabular}

The final reaction products are another concern that has been extensively tested because they are closely related to the removability of the polymers and their estrogenicity in water. Meanwhile, recognizing the reaction products provides valuable reference for concluding the reaction pathways.

$\mathrm{Yu}$ et al. $1994 \mathrm{i}$ dentified five dimeric and one trimeric products from the reaction aqueous solution. He further concluded that the two monophenoxy radicals are likely to couple at the 
oxygen, ortho and para atoms of a molecular based on the detection of their high unpaired electron densities.

Huang et al. (2005) systematically investigated into the mechanisms for removal of bisphenol A (BPA) from aqueous phase with HRP-OXC reaction. A total of 13 reaction intermediates and products are identified using LC/MS and GC/MS techniques, and detailed reaction pathways are proposed with the help of ab initial molecular modeling. $9 \mathrm{compounds}$ were detected in the liquid phase while 6 in the solvent extract of precipitate. 4isopropenylphenol is a major intermediate involved in the reaction. By examining the "spin density" and "charge density" of each atom of the molecule, they concluded that two phenoxy radicals are most likely to couple between atom 1 on one radical and atom $5^{\prime}$ on the other (the prime is used to indicate an atom on a different radical). An elimination of isopropylphenol carboncation will follow to reduce the steric instability around atom $5^{\prime}$ and increase electronic stability of the benzene ring.

\subsubsection{Kinetics Determining Factors}

Substrate reactivity is one of the most critical factors affecting the successful application of OXC in advanced wastewater treatment for the removal of phenolics. However, there have been limited research conducted addressing this issue. As reflected in the reaction rates of different substrates, the intrinsic reacting nature of substrate was claimed to be critical in determining the reaction rate.

Researchers have used molecular orbital theory in an attempt to construct quantitative structure activity relationships (QSAR) that inform HRP-OXC; these results have produced intriguing but at times inconsistent correlations with respect to the reaction rate. 
Several studies showed varying levels of success in generating correlations between the turnover number $\left(\mathrm{k}_{\mathrm{cat}}\right)$ and energy of the highest-occupied molecular orbital ( $\left.\mathrm{E}_{\mathrm{HOMO}}\right)$. Sakurada et al. 1990 observed a linear relationship between $\mathrm{E}_{\mathrm{HOMO}}$ and the logarithmic of the rate constant for phenolics with the correlation coefficient being 0.641. Brewster et al. 1991 observed similar trend with 33 compounds, but the correlation coefficient is slightly lower as 0.56 . Later, when Van et al. 1996 carried out such reaction, he found a clear linear relationship with 8 phenolic substrates with a correlation coefficient of 0.977 . Colosi et al. 2006 reported their correlation coefficient to be 0.976 . However, they also indicated that only a portion of the data fits the $\mathrm{E}_{\text {номо Vs. }} \mathrm{k}_{\text {cat }}$ trend. Considering all the points deviating possess a negative residue, they further doubt that molecular size might be a factor and HRP appears to be more capable of mediating smaller chemicals degradation.

Correlations between $\mathrm{k}_{\mathrm{cat}}$ and the energy of the lowest unoccupied molecular orbital ( $\mathrm{E}_{\mathrm{LUMO}}$ ) have also produced mixed results for substituted phenols (Sakurada et al., 1990, Brewster et al., 1991, Hosoya et al., 1983, Colosi et al., 2006). Sakurado et al. 1990 and Brewster et al. $1991 \mathrm{r}$ eported fairly strong correlations with coefficient of 0.86 and $0.89 \mathrm{r}$ espectively between compound II reactivity and the $\mathrm{E}_{\mathrm{LUMO}}$ for sets of substituted phenols. However, Hosoya et al. 1983 and Colosi et al. 2006 reported no significant correlation for a set of similar substrates.

Atomic charge distribution and the Hammet constant were also studied. Despite early work by Bordeleau et al. 1972 indicating a correlation between compound II reactivity and atomic charge on the substrate's phenolic oxygen, Hosoya et al. 1983 and Sakurada et al. 1990 were unable to confirm significant correlation. Job et al. 1976, Dunford et al. 1986, Sakurada et 
al. 1990, and Gilabert et al. 2004 ha ve reported significant correlations between the Hammer constant of the substrates and their reaction rates with both compound I and II.

These earlier investigations focused on correlating reaction rate to molecular or electronic structures of the substrates but neglected enzyme-substrate binding interactions. Recently, more efforts have accounted for enzyme-substrate binding features.

Colosi et al. 2006 found that the HRP reactivity is related to the binding distance with respect to His $42 \mathrm{r}$ esidue of the HRP/substrate binding complex. The paper reported that a shorter binding distance led to a faster reaction rate. Colosi et al. 2010 went on to engineer HRP proteins in which the active pocket was opened, and they determined that HRP reactivity (i.e. $\left.\mathrm{k}_{\mathrm{cat}}\right)$ was reasonably correlated $\left(\mathrm{R}^{2}=0.81\right)$ with predicted binding distances.

\subsubsection{Concerns on Oxidative Coupling Reaction}

Although promising results have been found, the development of a system using enzyme to catalyze the polymerization of phenolics remains in its infancy. Research has shown that OXC for phenol removal is highly efficient and wide applicable, but some issues must be addressed before it can proceed to be employed on field.

\section{Enzyme inactivation}

It has been well demonstrated and widely accepted that HRP is easily susceptible to inactivation, leading to a much lower and unclear catalytic activity than predicted (Kathy et al., 1994). The inactivation factors or kinetics are not confirmed yet, thus there is lack of guidance on its proper application.

Three possible pathways have been proposed for HRP inactivation. The first is by reaction with $\mathrm{H}_{2} \mathrm{O}_{2}$; i.e., both compounds I and II react with excessive peroxide to form different 
inactive species (Nakajima et al., 1987). The second involves sorption/occlusion by polymeric products; i.e., HRP adsorbs on the precipitated products formed from phenol coupling. When large amounts of precipitate are formed, HRP becomes entrapped and its active sites occluded (Nakamoto et al., 1992). In the third possible pathway free phenoxyl radicals can react with HRP, leading to an inactive state (Klibanov et al., 1983; Huang et al. 2005). Huang et al. 2005 observed more than $50 \%$ of HRP activity loss at various phenol and peroxide concentrations and concluded that at environmental relevant low concentrations, inactivation by excessive $\mathrm{H}_{2} \mathrm{O}_{2}$ and phenoxyl radical dominates. Considering the discussion above, enzyme protection becomes a critical issue. For example, when polyethylene glycol (PEG), a hydrophilic synthetic polymer, is present as additives, up to a 200 -fold reduction in the amount of enzyme needed was observed (Wu, et al. 1993; Wu, et al. 1998). But PEG will increase the chemical oxygen demand (COD), thus deteriorate water quality to a certain degree.

\section{Wastewater characteristics}

Another issue relating to the application of OXC is the fact that actual wastewater is a matrix of various constituents, thus the impacts of these substance on the treating efficiency cannot be ignored. However, little data are available in the literature on the removal of steroid estrogens from real wastewater combined with the disappearance of their corresponding estrogenicity.

Auriol et al. 2007 used OXC to remove steroid estrogens in both synthetic water and real activated sludge process effluent. He found that an HRP dose of 8-10 unit/ml (U/ml) was required to completely remove all the studied estrogens in real wastewater while only 0.032 $\mathrm{U} / \mathrm{ml}$ for treating synthetic water containing the same estrogen concentration. They speculated that HRP first oxidizes other organic compounds (such as phenols, alkylphenols, BPA) present 
in wastewater before oxidizing estrogens which are present in wastewater at lower concentrations than the above mentioned compounds. However, this hypothesis remains unproven.

Extensive study has been carried out addressing the catalytic activity under different reaction conditions. Auriol et al. 2006 showed that optimum pH for HRP-catalyzed treatment was at near neutral conditions for each estrogen. Meanwhile, they found the decrease in the removal efficiency at temperatures between 5 and $25^{\circ} \mathrm{C}$ was two to three times greater for $\mathrm{E} 1$, E2, and $\mathrm{E} 3$ than for EE2. However, there is no explanation explaining this phenomenon. Huang et al. 2005 didn't observe considerable total phenol conversion variance with $\mathrm{pH}$ changes although he found that precipitation of coupling products increased significantly as solution $\mathrm{pH}$ values decreased from $\mathrm{pH} 5$ to $\mathrm{pH} 3$.He postulated that phenol coupling products are more acidic than that of phenol due to stronger resonance effects, and as solution $\mathrm{pH}$ drops, protonation of the acidic sites reduces products ionic character and increases their tendency to precipitate. At the same time, his results indicated that salts addition will increase the precipitation cause by decreasing the solubility of the products.

\section{Estrogenicity removal}

Limited data are available in the literature on the removal of steroid estrogens from real wastewater treatment by enzymatic systems, combined with the disappearance of their corresponding estrogenicity. Auriol et al. 2008 looked at the removal of estrogenicity associated with the studied steroid estrogens $\left(\mathrm{E}_{1}, \mathrm{E}_{2}, \mathrm{E}_{3}\right.$, and $\left.\mathrm{EE}_{2}\right)$ from a municipal wastewater by both HRP and laccase catalyzed processes. Both enzymatic treatments were very efficient in removing the estrogenic activity of the studied steroid estrogens. 


\section{Economic aspects of enzyme production and downstream treatment}

The cost of a treatment approach is the most important fact determining its applicability in large scale. OXC is very efficient, but the HRP requirements are significant and, as a result, full scale application is probably limited to sidestream treatment. Van de Velde et al. 2001 make

the general point that scale-up of HRP catalyzed oxidation to industrial level will require a substantial reduction in the price of enzyme. Solutions to this problem may include better process management of hydrogen peroxide to avoid enzyme inactivation, immobilization of the enzyme and use of engineered enzymes with improved stability and catalytic efficiency.

After the OXC reaction, the reaction solution needs to be filtered to remove the precipitates. Separation membranes need to be applied and this raises other critical issues related to membrane filtering process, especially membrane fouling and the energy input.

\subsubsection{Critique of The Literature}

As indicated by the aforementioned reaction mechanism, HRP takes part in the reaction by generating organic radicals before returning to the initial state. So the interaction between enzyme and the substrate is critical. Although previous work highlighted the importance of enzyme-substrate binding features, there are, however, other hitherto undetermined factors that influence enzyme-substrate interaction. These include critical thermodynamics parameters (e.g. enthalpy and entropy of activation) and enzyme-substrate binding energy.

Meanwhile, as the reaction was carried out in aqueous phase, it is important to consider the participation of water molecules in OXC because solvent was shown to play an important role in determining enzymatic reaction kinetics (Janssen et al., 1999). However, there is currently no information investigating into this aspect. 


\subsection{RESEARCH HYPOTHESIS AND OBJECTIVES}

HRP functions by lowering the activation energy for a given reaction. Therefore, it is expected that lowering the activation energy will correspond to higher reaction rates. The hypothesis of this study is:

$>$ The higher reaction rates can be correlated to key parameters such as:

\#1) the binding distances between the steroidal estrogens and the HRP active site, \#2) the magnitude of the observed entropy change.

$>$ The speed of HRP-OXC will be governed by enzyme substrate interactions, not diffusion.

The overall goal of the current work is to examine the kinetics and reaction mechanisms associated with HRP-OXC, particular attention was paid to issues that inform enzyme-substrate interactions. The specific objectives are to:

$>$ Evaluate reaction kinetics over a range of temperatures;

$>$ Investigate kinetic limitations;

Analyze enzyme-substrate interactions;

$>$ Obtain thermodynamic parameters.

Five phenolic substrates (phenol, $E_{1}, E_{2}, E_{3}, E_{2}$ ) were used for pursuing these objectives. These compounds have very similar structural properties, but because the ring $\mathrm{D}$ functional groups are different, the binding properties and OXC kinetics were expected to be different. 


\subsection{CHEMICAL KINETICS AND INTERACTIONS INVOLVED IN HORSERADISH PEROXIDASE MEDIATED OXIDATIVE POLYMERIZATION OF PHENOLIC COMPOUNDS}

\subsection{MATERIALS AND METHODOLOGY}

\subsubsection{Experimental Overview}

Five phenolic substrates were spiked into deionized (DI) water. $150 \mathrm{ml}$ beakers with magnetic stir bars were applied as reactors, and the reaction kinetics and orders were determined by obtaining the initial reaction rate over a range of phenolic concentrations (i.e. $2 \mu \mathrm{M}$ to $5 \mu \mathrm{M}$ ). Enthalpy of activation $\left(\Delta \mathrm{H}^{*}\right)$ and entropy of activation $\left(\Delta \mathrm{S}^{*}\right)$ were determined with data collected at different temperatures $\left(5^{\circ} \mathrm{C}, 15^{\circ} \mathrm{C}, 25^{\circ} \mathrm{C}, 35^{\circ} \mathrm{C}\right)$. Е Номо were calculated with the Gaussian 03 program and molecular volume for each substrate was gained using their molecular weights and densities. Enzyme-substrate interactions were simulated w ith AutoDock 4.2. Binding energies and binding distances were determined.

\subsubsection{Materials}

The following materials were purchased from Sigma-Aldrich (St. Louis, MO): phenol (CAS 108-95-2), steroidal hormones E1 (CAS 53-16-7), E2 (CAS 50-28-2), E3 (CAS 50-27-1), 
EE2 (CAS 57-63-6), hydrogen peroxide (50 wt\%, CAS 7722-84-1), extracellular horseradish peroxidase (type I, RZ=1.3), polyethylene glycol (CAS 25322-68-3), 4-aminoantipyrine (AAP) (CAS 83-07-8), reagent-grade acetonitrile (CAS 75-05-8), and methanol (CAS 67-56-1).

\subsubsection{Enzyme Activity Assay}

A colorimetric assay was used to measure the HRP activity and concentration. The enzyme activity is proportional to the production rate of a constituent that absorbs light at a peak wavelength of $510 \mathrm{~nm}$ and with an extinction coefficient (e) of $7100 \mathrm{M}^{-1} \mathrm{~cm}^{-1}$. The assay mixture consisted of $10 \mathrm{~m} \mathrm{M}$ phenol, $2.4 \mathrm{~m} \mathrm{M}$ AAP, and $0.2 \mathrm{~m} \mathrm{M} \mathrm{H}_{2} \mathrm{O}_{2}$. One unit of activity (U) was defined as the number of micromoles of hydrogen peroxide utilized per minute at $\mathrm{pH} 7.4$ and $25^{\circ} \mathrm{C}$ (Wagner and Nicell, 2002). Absorbance at $510 \mathrm{~nm}$ was monitored with a UV/VIS spectrophotometer (Spectronic 20, Bausch \& Lomb) every 5 seconds for 1 minute following a reaction initiation. All assays were performed in triplicate. Relative standard deviations (RSD) of triplicate measurements were always less than $5 \%$.

\subsubsection{Initial Reaction Rate}

Initial reaction rate was determined according to the most common practice in the study of enzymatic catalysis (Blanch and Clark, 1997). HRP-OXC reactions were carried out at $25^{\circ} \mathrm{C}$ in $100 \mathrm{~m} 1$ of phosphate buffer $(50 \mathrm{mM}, \mathrm{pH}=7.0)$ using $150 \mathrm{ml}$ beakers with various initial concentrations of substrate and a fixed dosage of $\mathrm{HRP}$ and $\mathrm{H}_{2} \mathrm{O}_{2}$. PEG was added to protect HRP from oxidative damage, as suggested by Nakamoto et al., 1992. For $\mathrm{E}_{1}, \mathrm{E}_{2}, \mathrm{E}_{3}$ and $\mathrm{EE}_{2}, 1 \mathrm{mM}$ methanol stock solutions were made and the reaction mixtures were prepared by diluting the 
stock solution to the desired concentration (between $2 \mu \mathrm{M}$ and $5 \mu \mathrm{M}$ ). For phenol, $1 \mathrm{mM}$ stock solution in water was made and reaction solution was made by diluting the stock solution. Batch reactors were mixed at $300 \mathrm{rpm}$ with a Teflon-coated magnetic bar at neutral $\mathrm{pH}$. Each reactor contained the appropriate mass of substrate, $10 \mu \mathrm{M} \mathrm{H}_{2} \mathrm{O}_{2}$, and $30 \mathrm{mg} / \mathrm{l} \mathrm{PEG}$, and the reaction was initiated by adding HRP. The initial HRP activity was $0.37 \mathrm{U} / \mathrm{ml} .10 \mu \mathrm{M} \mathrm{H}_{2} \mathrm{O}_{2}$ concentration was selected to obtain a molar peroxide-to-substrate ratio of 2.0-5.0, as suggested by previous work (Auriol et al., 2007, Sakurai et al., 2001, Kinsley and Nicell, 2000). 2-ml aliquots were took from from the batch reactors every 10 seconds for the first 20 seconds, and the reaction was stopped by adding $0.1 \mathrm{~mL}$ of $10 \%$ phosphoric acid. Then acidified samples were filtered through a 0.45 $\mu \mathrm{m}$ syringe filter (Pall Life Science Inc., Ann Arbor, MI).Each experiment was done in triplicate.

\subsubsection{HRP-OXC on Real Wastewater}

In order to determine if the developed enzymatic system was still feasible and effective with real wastewater as well as to compare the kinetic difference between synthetic water and wastewater, $E_{1}, E_{2}, E_{3}$ and $E_{2}$ were spiked into the prefiltrated secondary effluent taken from Bethel Park/South Park Municipal Authority as to a concentration of $1 \mathrm{mg} / \mathrm{L}$. Batch reactors, containing predetermined amount of phenolic substrate, $40 \mu \mathrm{M} \mathrm{H}_{2} \mathrm{O}_{2}$ and $120 \mathrm{mg} / \mathrm{L}$ PEG were agitated with a Teflon-coated magnetic bar at neutral $\mathrm{pH}$ with $\mathrm{rmp} 300.2 .3 \mathrm{ml}$ 65U/L HRP solution was added to the solution to initiate the reaction. A 2-ml aliquot of the reaction solution was taken every 10 seconds for the first 40 seconds and also at $3 \mathrm{~min}, 10 \mathrm{~min}, 35 \mathrm{~min}$ and it was mixed immediately with $0.1 \mathrm{~mL}$ of $10 \%$ phosphoric acid to stop the reaction. The acidified sample was then filtered through a 0.45 -um syringe filter for the subsequent HPLC analysis. 


\subsubsection{HPLC Analysis of Phenolic Substrates}

Agilent 1200 series high-performance liquid chromatography (HPLC) equipped with an Elipse XDB-C18 column (150*4.6 mm, $5 \mu \mathrm{m}$ particle size) was used in this study (Figure 7). Estrogen concentrations were measured using UV absorbance (wavelength $=197 \mathrm{~nm}$ ) with external calibration. The mobile phase consisted of $40 \%$ reagent-grade acetonitrile (ACN) and $60 \%$ deionized water (DI). The flow rate was $1.0 \mathrm{ml} / \mathrm{min}$. The retention times for each substrate were $3.03 \min \left(\right.$ phenol), $12.31 \min \left(E_{1}\right), 7.27 \min \left(E_{2}\right), 2.05 \min \left(E_{3}\right)$, and $10.24 \min \left(E_{2}\right)$.

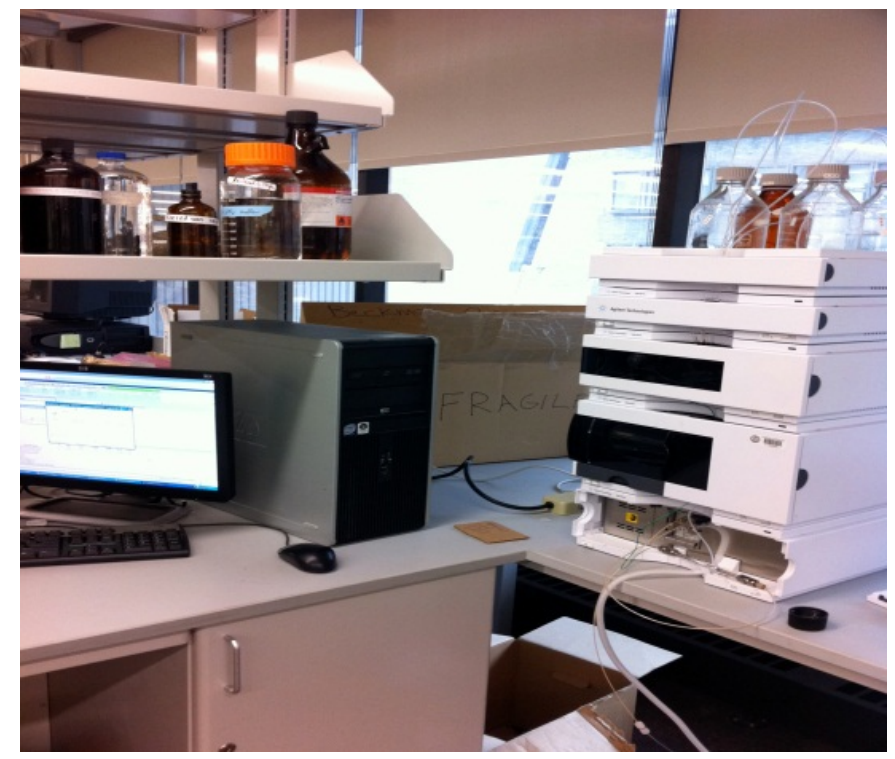

Figure 7. Agilent 1200 series high-performance liquid chromatography (HPLC)

\subsubsection{Kinetic and Thermodynamic Determination}

The initial reaction rate $\left(\mathrm{v}_{\mathrm{a}}\right)$ is related to the substrate concentration as shown in the following equation:

$$
v_{a}=\left|\frac{d\left[A_{0}\right]}{d t}\right|=\left(k\left[B_{0}\right]^{m}\right)\left[A_{0}\right]^{n}=k_{r}\left[A_{0}\right]^{n} \text { (eq. 1) }
$$


Where A represents the substrate, $\mathrm{B}$ is the $\mathrm{H}_{2} \mathrm{O}_{2}, \mathrm{k}_{\mathrm{r}}$ is a reaction rate constant, and $\mathrm{n}$ is the reaction order. $\mathrm{k}_{\mathrm{r}}$ and $\mathrm{n}$ were determined by plotting $\log \left(\mathrm{v}_{\mathrm{a}}\right) \mathrm{vs} . \log \left[\mathrm{A}_{0}\right]$.

The reaction rate constants at different temperatures were calculated using the following:

$$
\frac{v_{a T}}{v_{a 298 K}}=\frac{\left(k_{T}\left[B_{0}\right]^{m}\right)\left[A_{0}\right]^{n}}{\left(k_{298 K}\left[B_{0}\right]^{m}\right)\left[A_{0}\right]^{n}}=\frac{k_{r T}}{k_{r 298 K}}(\text { eq. 2) }
$$

The thermodynamic parameters $\Delta \mathrm{H}^{*}$ and $\Delta \mathrm{S}^{*}$ were determined using a linear regression of Eyring's equation:

$$
\ln \frac{k}{T}=\frac{-\Delta H^{*}}{R} * \frac{1}{T}+\ln \frac{k_{B}}{h}+\frac{\Delta S^{*}}{R}(\text { eq. } 3)
$$

The Eyring equation was transformed by substituting $k_{r}=k^{*}\left[B_{0}\right]^{m},\left[\mathrm{H}_{2} \mathrm{O}_{2}\right]=10 \mu \mathrm{M}$, and $\mathrm{m}=1$ (Yu et al., 1994):

$$
\ln \frac{k_{r}}{T}=\frac{-\Delta H^{*}}{R} * \frac{1}{T}+\ln \frac{k_{B}}{h}+\frac{\Delta S^{*}}{R}-9.21(\text { eq. } 4)
$$

$\mathrm{R}$ is the ideal gas constant $(8.314 \mathrm{~J} / \mathrm{mol} * \mathrm{~K}), \mathrm{k}_{\mathrm{B}}$ is Boltzmann constant, $\mathrm{h}$ is Planck's constant, and $\mathrm{T}$ is temperature in Kelvin. The free energy of activation was calculated as follows:

$$
\Delta G^{*}=\Delta H-T^{*} \Delta S^{*}(\text { eq. } 5)
$$

\subsubsection{Collision Kinetics}

Collision theory assumes that collision of molecules results in reaction and it establish an upper limit for rates of reaction based on the diffusion of reactants. For a bimolecular reaction in liquid, the bimolecular rate constant $\mathrm{k}^{\text {coll }}$ can be expressed as: 


$$
k^{\text {coll }}=Z * p * e^{\left(-\frac{E_{a c t}}{R T}\right)}(\text { eq. } 6)
$$

Where $\mathrm{Z}$ is the frequency of collisions and $\mathrm{p}$ is the fraction of molecules that have the correct orientation for reaction and $\mathrm{E}_{\mathrm{act}}$ is the activation energy. The diffusion-limited maximum rate constant will occur when all molecules have the correct orientation $(p=1)$ and the activation energy is zero. And in condition of this, $\mathrm{k}^{\text {coll }}=\mathrm{Z}$ and $\mathrm{Z}$ can be calculated as:

$$
Z=\frac{4 * \pi * N_{A v o}^{*}\left(D_{A}+D_{B}\right) *\left(r_{A}+r_{B}\right)}{1000}(\text { eq. } 7)
$$

Where $\mathrm{N}_{\mathrm{avo}}$ is the Avogadro's number $\left(\mathrm{N}_{\mathrm{avo}}=6.02 * 10^{23} / \mathrm{mol}\right), \mathrm{D}_{\mathrm{A}}$ and $\mathrm{D}_{\mathrm{B}}$ is the diffusion coefficient of phenolic substrate and HRP $\left(\mathrm{D}_{\mathrm{A}}=6.8^{*} 10^{-7} \mathrm{~cm}^{2} / \mathrm{s}(\right.$ Cecil et al., 1951$\left.)\right) . \mathrm{r}_{\mathrm{A}}$ and $r_{B}$ is the radii of $\operatorname{HRP}\left(r_{B}=30 \AA\right)$ and phenolic substrate.

D can be calculated according to Stokes-Einstein equation,

$$
D=\frac{k_{B} T}{6 \pi \eta r}(\text { eq. 8) }
$$

Where $\mathrm{k}_{\mathrm{B}}$ is the Bolzmann constant $\left(1.3806503 \times 10^{-23} \mathrm{~m}^{2} \mathrm{~kg} \mathrm{~s}^{-2} \mathrm{~K}^{-1}\right)$ and $\eta$ is the fluid viscosity (for water, $\eta=0.890 * 10^{-3} \mathrm{~kg} \mathrm{~m}^{-1} \mathrm{~s}^{-1}$ ).

\subsection{9 $\quad$ Еномо Calculation}

$\mathrm{E}_{\mathrm{HOMO}}$ was calculated using the Gaussian 03 program via the Pittsburgh supercomputer center. Structure optimization of the model compound was conducted with 6-31G (d) basis set at level of Unrestricted Hartree-Fock (UHF). After structure optimization, Eномо of the model compounds were calculated in the same method and basis set. 


\subsubsection{Docking Simulation}

Autodock 4.2 was used to simulate the binding between the five phenolic compounds and HRP. At least ten possible conformations were determined and, for the purposes of this comparative study, selected those that were associated with the lowest binding energy because lower energy states are more stable. The Lammarckian genetic algorithm (GA) method was used to calculate free energy changes. In Autodock 4.2, a docking box of $100 * 100 * 100$ points with a grid spacing of $0.375 \AA$ was created. The structural coordinates of the model horseradish peroxidase compound II (1H55) was downloaded from the Research Collaboratory for Structural Bioinformatics Protein Data Bank (RCSBPDB). crystallographic water molecules were removed from the active site before docking, and hydrogen atoms and partial charges were added using the Assisted Model Building with Energy Refinement (AMBER) force field. The Gasteiger Partial Equalization of Orbital Electronegativities method was then used to assign partial charges to HRP and the phenolic substrates. The coordinates of phenolic substrate were used as the initial position for the docking simulation; HRP was superimposed on the phenolic substrate to obtain an initial position. The flexible amino acids residues were HIS42, ARG38, PHE41, and ASN70. The binding distance was between the substrate's phenolic proton and the imidazole $\delta \mathrm{N}$ on the HIS42 residue as suggested previously (Colosi et al., 2006). 


\subsection{RESULTS AND DISCUSSION}

\subsubsection{Reaction Kinetics of Estrogens}

Although the studied estrogens have similar structures, their reactivity varies considerably. Figure 8 shows the two-dimensional logarithmic graphs associated with the oxidative coupling reactions carried out in this study. The initial reaction rate was highest for $\mathrm{EE}_{2}$, followed by (in decreasing order) $\mathrm{E}_{2}, \mathrm{E}_{1}, \mathrm{E}_{3}$ and phenol. The slopes of the log-log regressions reveal the reaction order, which was close to 1 for all the substrates. The result of reaction order is in keeping with the conclusions of Auriol et al., 2007. The y-intercept of each regression is the $\log \left(\mathrm{k}_{\mathrm{r}}\right)$, which indicates the pseudo rate constant with respect to estrogen substrates. This value is greatest for $\mathrm{EE}_{2}(-1.193)$, followed by $\mathrm{E}_{2}(-1.566), \mathrm{E}_{1}(-1.592), \mathrm{E}_{3}(-$ 1.920), and phenol (-2.110). These kinetic differences are strongly influenced by substrate affinity, and three approaches are shown to illustrate the hypothesis. First, the Lineweaver-Burke approach was used to determine Michaelis-Menten parameters $\left(\mathrm{K}_{\mathrm{m}}\right.$ and $\left.\mathrm{k}_{\text {cat }}\right)$ (Table 8). These data show that HRP had the greatest affinity for $\mathrm{EE}_{2}\left(\mathrm{~K}_{\mathrm{m}}=14.55 \mu \mathrm{M}\right)$, followed by (in decreasing order $) \mathrm{E}_{1}\left(\mathrm{~K}_{\mathrm{m}}=23.58 \mu \mathrm{M}\right), \mathrm{E}_{3}\left(\mathrm{~K}_{\mathrm{m}}=59.48 \mu \mathrm{M}\right), \mathrm{E}_{2}\left(\mathrm{~K}_{\mathrm{m}}=78.31 \mu \mathrm{M}\right)$ and phenol $\left(\mathrm{K}_{\mathrm{m}}=93.78 \mu \mathrm{M}\right)$. This $\mathrm{K}_{\mathrm{m}}$ order is generally consistent with the reaction rate order. Second, the observed reaction rates constants were compared to the diffusion-limited maximum reaction rate constant, and it is determined that the second order bimolecular collision rate constant $\left(\mathrm{k}^{\text {coll }}\right)$ was on the order of $10^{10} \mathrm{M}^{-1} \mathrm{~s}^{-1}$, which is several orders of magnitude higher than the observed rate constants or those reported by Auriol et al., 2007 (i.e. $1.56 * 10^{6} \mathrm{M}^{-1} \mathrm{~s}^{-1}$ ). Third, $\mathrm{k}_{\mathrm{r}}$ does not correlate with $\mathrm{k}_{\text {cat }}$ as shown by Figure 9 . For example, phenol and $\mathrm{EE}_{2}$ have similar $\mathrm{k}_{\text {cat }}$ value $\left(\mathrm{k}_{\mathrm{cat}}=0.083 / \mathrm{s}\right.$ for phenol and $\mathrm{k}_{\text {cat }}=0.086 / \mathrm{s}$ for $\left.\mathrm{EE}_{2}\right)$ but very different reaction rate constants. 
Similarly, $E_{1}$ reacts faster than $E_{3}$, but its $k_{\text {cat }}$ value $\left(0.0567 / \mathrm{s}\right.$ for $E_{1}$ and $0.067 / s$ for $\left.E_{3}\right)$ is lower than that of $E_{3}$. Similar observations can be made with data published previously by Auriol et al., 2007. Interestingly, $\mathrm{k}_{\mathrm{cat}}$ is positively correlated with $\mathrm{E}_{\text {НОмо }}$ (Colosi et al., 2006), which makes sense because $\mathrm{k}_{\text {cat }}$ and $\mathrm{E}_{\text {Hомо }}$ relate to the maximum reaction rate potential. It is also determined that $\mathrm{k}_{\mathrm{r}}$ does not correlate well with $\mathrm{E}_{\mathrm{HOMO}}$ as shown by Figure 10. OXC kinetics does not depend solely on reaction rate potential and they are not diffusion limited, but instead it is controlled by enzyme-substrate interactions. Figure 11 shows a linear relationship of $\mathrm{k}_{\mathrm{r}}$ and $\mathrm{K}_{\mathrm{m}}$.

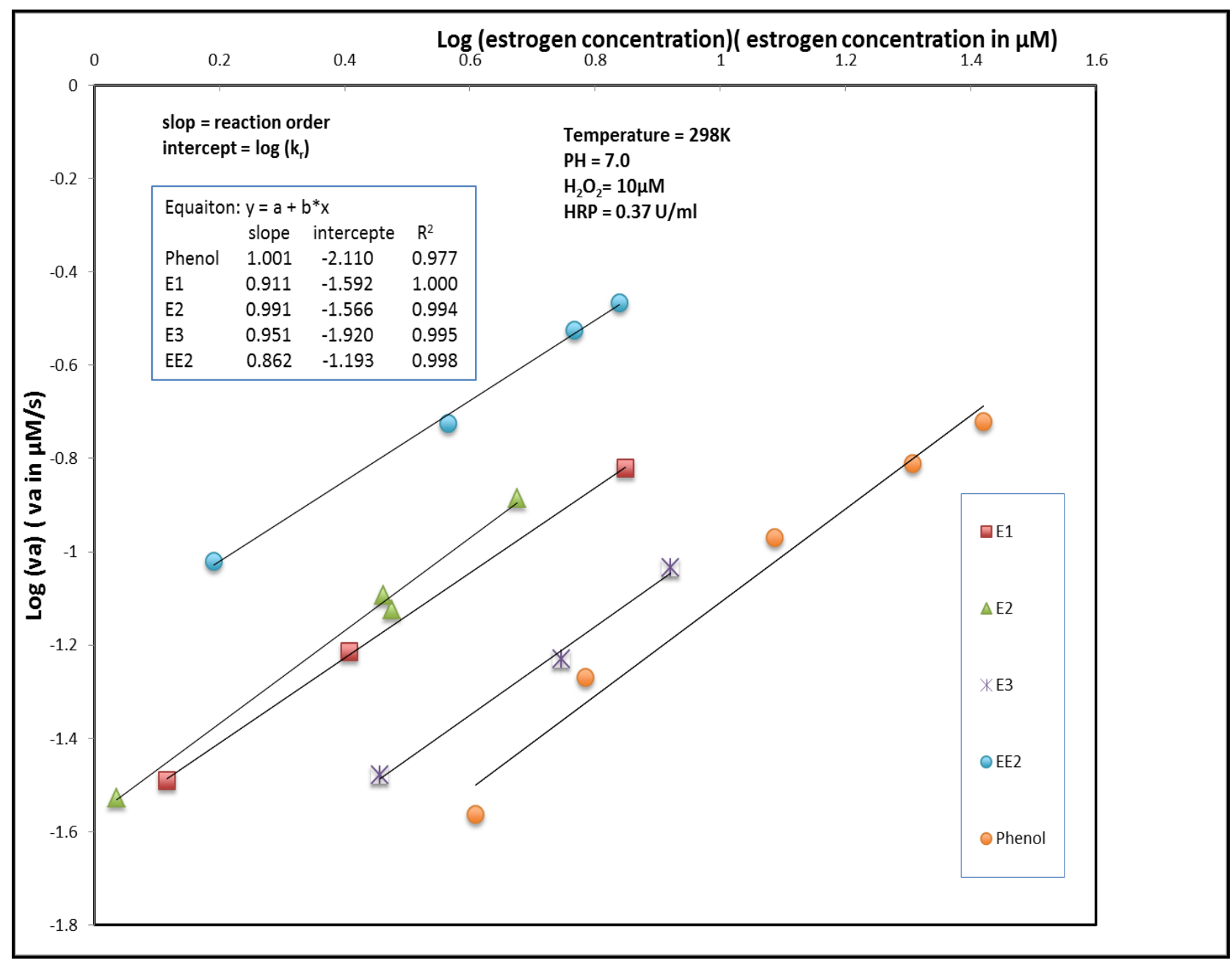

Figure 8. Estrogen reaction rates with different initial estrogen concentration 
Table 8. Measured rate constants and collision theory-based kinetics $\left(\mathrm{T}=25^{\circ} \mathrm{C}\right)$

\begin{tabular}{|c|c|c|c|c|c|c|}
\hline \multirow[b]{2}{*}{ Compound } & \multicolumn{2}{|c|}{$\begin{array}{l}\text { Michaelis-Menten } \\
\text { Model }\end{array}$} & \multirow[b]{2}{*}{$\begin{array}{l}\text { Apparent } \\
\text { second order } \\
\text { rate constant } \\
\mathrm{k}_{\mathrm{cat}} / \mathrm{K}_{\mathrm{m}} \\
\left(\mathrm{M}^{-1} \mathrm{~S}^{-1}\right)\end{array}$} & \multirow[b]{2}{*}{$\begin{array}{l}\text { Collision } \\
\text { Theory } \\
\text { rate } \\
\text { constant } \\
\left(\mathrm{k}^{\text {colll }}\right) \\
\left(\mathrm{M}^{-1} \mathrm{~S}^{-1}\right)\end{array}$} & \multirow[b]{2}{*}{$\begin{array}{l}\text { Radii } \\
\left(\mathrm{r}_{\mathrm{b}}\right) \\
(\AA)\end{array}$} & \multirow[b]{2}{*}{$\begin{array}{l}\text { Diffusion } \\
\text { coefficien } \\
\left({ }^{* *} D_{B}\right) \\
\left(\mathrm{cm}^{2} / \mathrm{s}\right)\end{array}$} \\
\hline & $\begin{array}{l}\mathrm{K}_{\mathrm{m}} \\
(\mu \mathrm{M})\end{array}$ & $\begin{array}{l}{ }^{*} \mathrm{k}_{\mathrm{cat}} \\
\left(\mathrm{s}^{-1}\right)\end{array}$ & & & & \\
\hline Phenol & 93.78 & 0.083 & $8.85^{*} 10^{2}$ & $1.89 * 10^{10}$ & 3.3 & $7.43 E-6$ \\
\hline $\mathrm{E}_{1}$ & 23.58 & 0.057 & $2.42^{*} 10^{3}$ & $1.48 * 10^{10}$ & 4.5 & $5.45 \mathrm{E}-6$ \\
\hline $\mathrm{E}_{2}$ & 78.31 & 0.142 & $1.81 * 10^{3}$ & $1.48 * 10^{10}$ & 4.5 & $5.45 \mathrm{E}-6$ \\
\hline $\mathrm{E}_{3}$ & 59.48 & 0.067 & $1.13^{*} 10^{3}$ & $1.48 * 10^{10}$ & 4.5 & $5.45 \mathrm{E}-6$ \\
\hline $\mathrm{EE}_{2}$ & 14.55 & 0.086 & $5.89 * 10^{3}$ & $1.45 * 10^{10}$ & 4.6 & $5.33 \mathrm{E}-6$ \\
\hline
\end{tabular}

$* \mathrm{k}_{\mathrm{cat}}=\mathrm{v}_{\max } /\left[\mathrm{E}_{\mathrm{t}}\right]$

**Calculated with the Stokes-Einstein equation as described in supplemental materials, Part I.

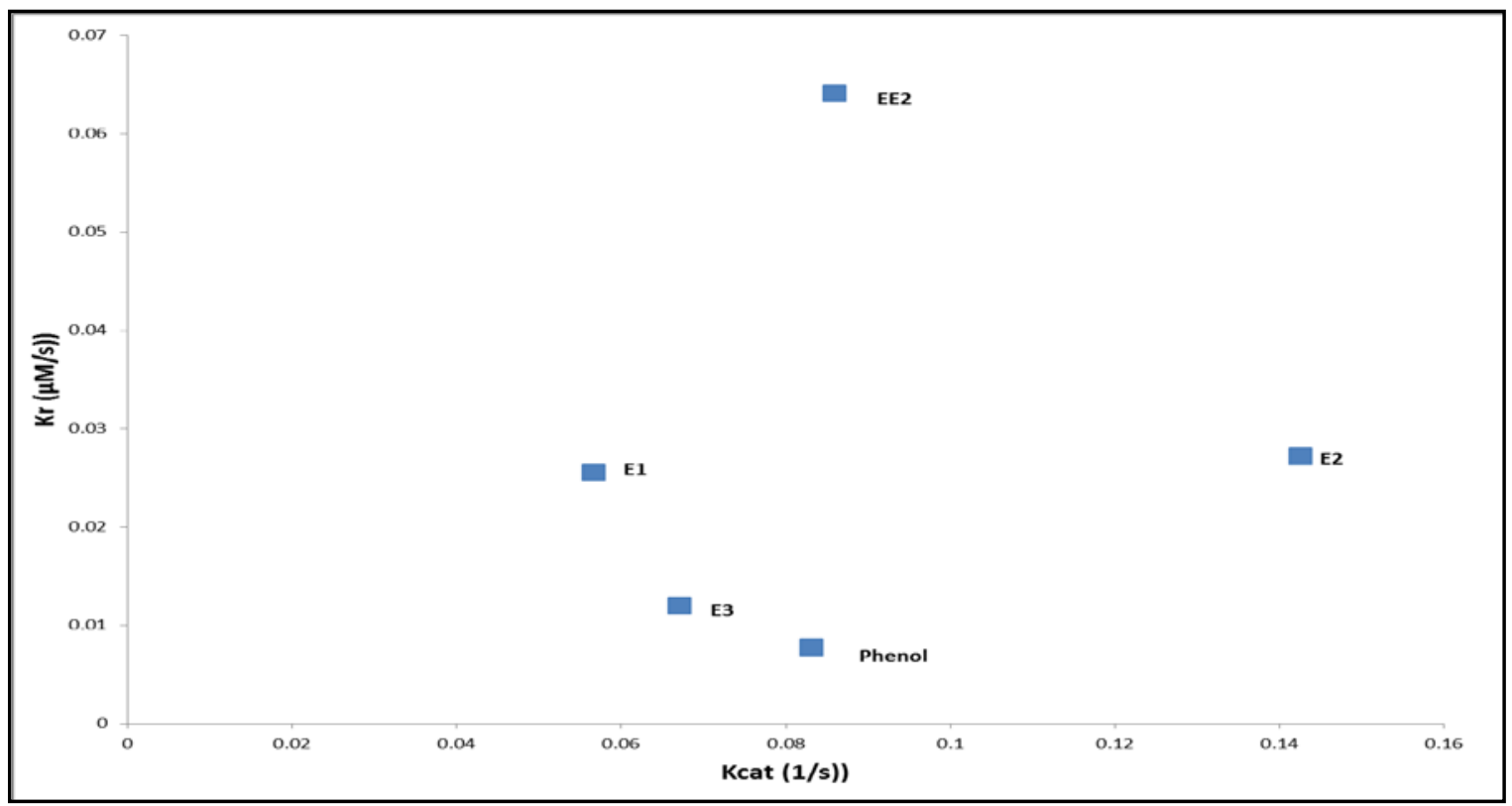

Figure 9. Relationship between $k_{r}$ and $k_{\text {cat }}$ for studied estrogens 


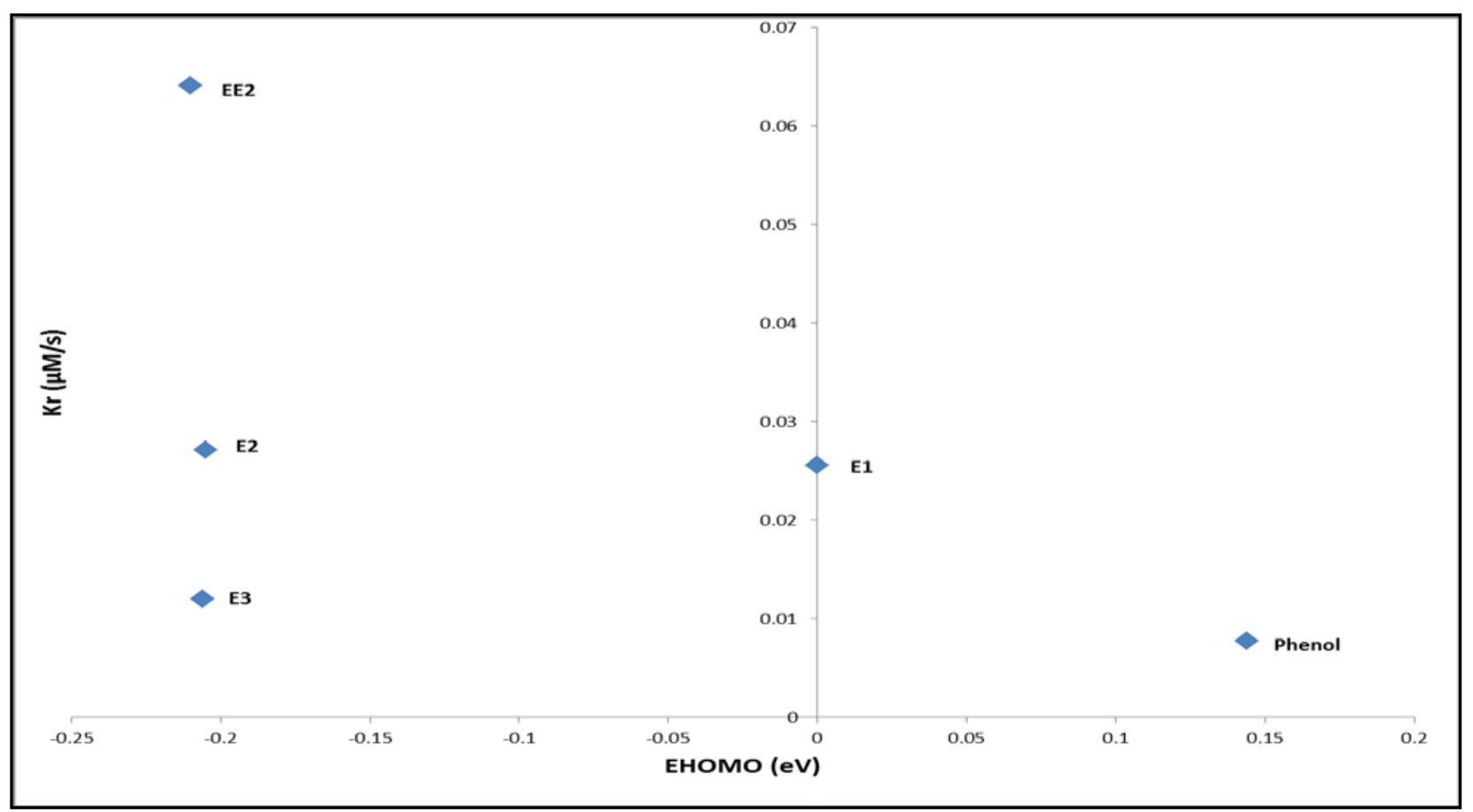

Figure 10. Relationship between $k_{r}$ and $E_{\text {номо }}$ for studies estrogens

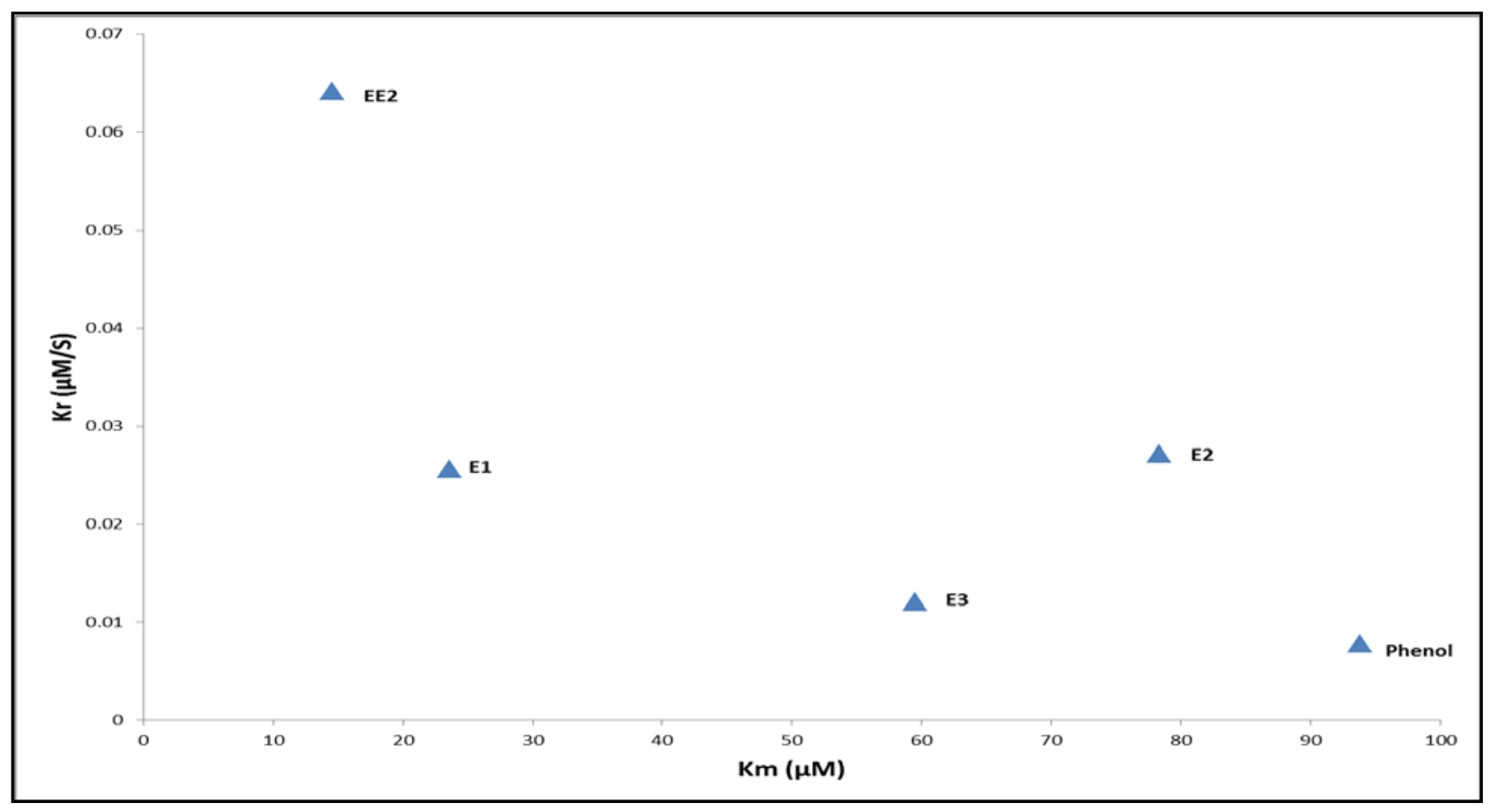

Figure 11. Relationship between $k_{r}$ and $K_{m}$ for studies estrogens 


\subsubsection{Molecular Volume and Substrate Binding}

The molecular volume of the substrates and two aspects of substrate binding, binding distance and energy were evaluated. Molecular volume (MV) affects the accessibility of the compound to the active site pocket of the HRP. The steroidal hormones have a similar molecular volume (between $230-244 \mathrm{~cm}^{3} / \mathrm{mol}$ ), but phenol has a lower value $\left(87.8 \mathrm{~cm}^{3} / \mathrm{mol}\right)$. Phenol also has the smallest reaction rate constant. $\mathrm{EE}_{2}$ occupies the largest molecular volume (MV $=244.4$ $\mathrm{cm}^{3} / \mathrm{mol}$ ) and reacts with the highest rate. This shows that molecular volume does not limit substrate reactivity. In principle, a larger compound may react slower due to steric hindrance, but this was not observed in the current study. Figure 12 shows the binding energy values, which are in principle determined by the complementarity of enzyme and substrate. The strength of these bonds depends on minimizing steric repulsion, the presence of unsolvated or unpaired charges, and sufficient hydrogen bonding. Binding energy reduces the free energy of the transition state, allowing for more favorable interactions. Phenol has the least favorable binding energy ( -3.54 $\mathrm{kcal} / \mathrm{mol}$ ), or releasing the smallest amount of free energy when it forms weak interactions with HRP. The other 4 compounds have higher binding energy values (i.e. $E_{2}(-6.45 \mathrm{kcal} / \mathrm{mol}), \mathrm{EE}_{2}(-$ $7.14 \mathrm{kcal} / \mathrm{mol}), \mathrm{E}_{1}(-7.6 \mathrm{kcal} / \mathrm{mol})$ and $\left.\mathrm{E}_{3}(-5.8 \mathrm{kcal} / \mathrm{mol})\right)$. These binding energy values are largely in line with binding distance values. Our simulations showed that phenol had the longest binding distance (7.05 $\AA$ ), as expected, while the binding distances for the four hormones were $6.09 \AA\left(\mathrm{E}_{1}\right), 6.04 \AA \mathrm{E}_{3}, 5.83 \AA\left(\mathrm{E}_{2}\right)$, and $6.47 \AA\left(\mathrm{EE}_{2}\right)$. The long binding distance helps explain why phenol is removed more slowly than the four hormones, which appear to fit the active site better than phenol does, even though their molecular volume is larger than that of phenol. Examples of the docking graph are shown in Figure 13 (Sanner et al., 2002). 


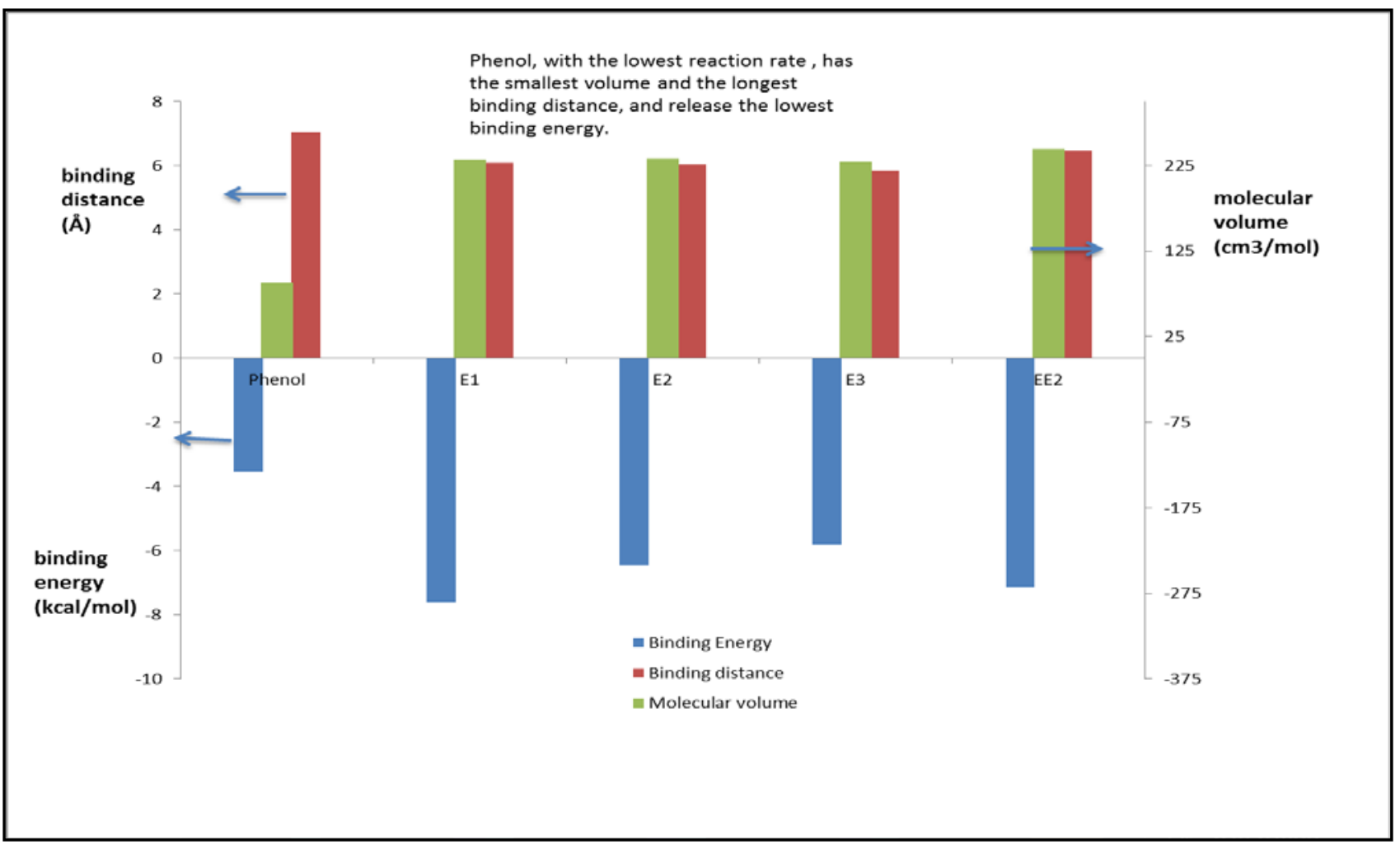

Figure 12. Molecular volume and binding properties from docking simulation

Conformation1: $-8.36 \mathrm{kcal} / \mathrm{mol}$

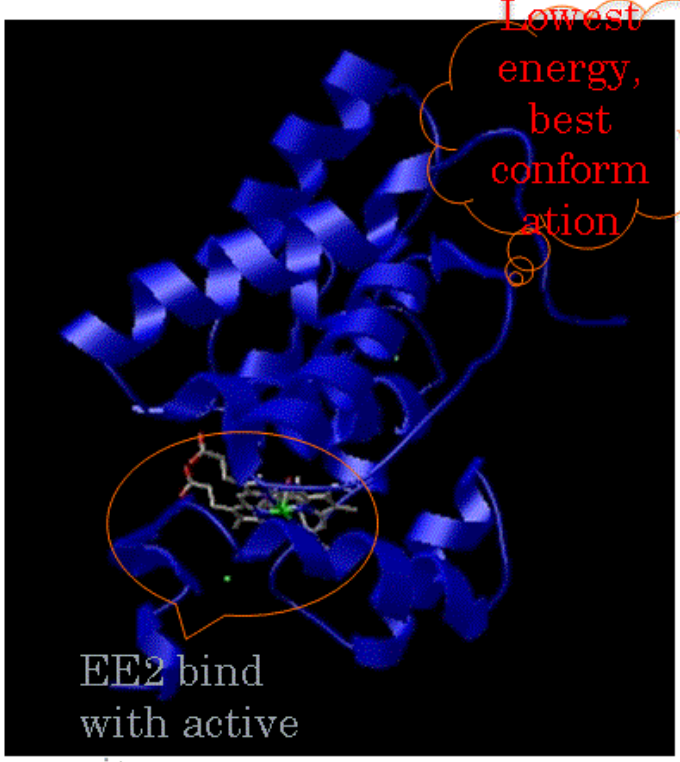

Conformation 2: $-6.69 \mathrm{kcal} / \mathrm{mol}$

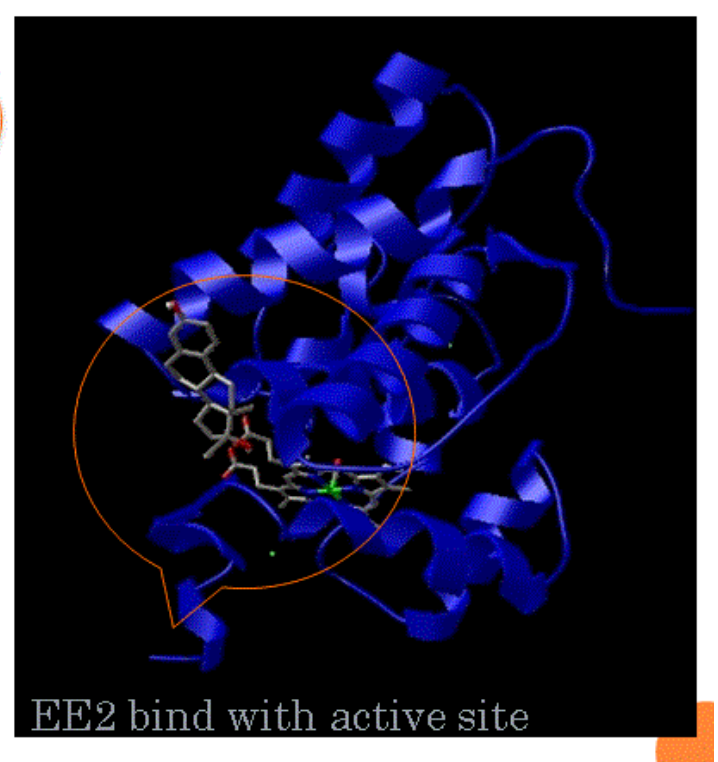

Figure 13. Docking simulation with Autodock 4.2 (example substrate: EE2) 


\subsubsection{Thermodynamic Parameters}

Figure 14 shows that at each temperature, $\mathrm{EE}_{2}$ had the largest reaction rate constant, followed by $E_{2}, E_{1}, E_{3}$ and phenol. The slopes of the linear regressions are negative, meaning that higher temperatures correspond to higher reaction rate constants. Meanwhile, the slopes are inversely related to the enthalpy of activation, which represents the difference in energy between the transition state and the ground state. As all the slopes are negative, it is determined that the activation enthalpies are positive and have values that decrease in the following order: EE2 (57.7 $\left.\mathrm{KJ}^{*} \mathrm{~K}^{-1} * \mathrm{~mol}^{-1}\right), \mathrm{E}_{2}\left(57.7 \mathrm{KJ}^{*} \mathrm{~K}^{-1} * \mathrm{~mol}^{-1}\right), \mathrm{E}_{1}\left(41.2 \mathrm{KJ}^{*} \mathrm{~K}^{-1} * \mathrm{~mol}^{-1}\right), \mathrm{E}_{3}\left(38.4 \mathrm{KJ}^{*} \mathrm{~K}^{-1} * \mathrm{~mol}^{-1}\right)$ and phenol $\left(22.0 \mathrm{KJ}^{*} \mathrm{~K}^{-1} * \mathrm{~mol}^{-1}\right)$. The activation entropies are related to the $\mathrm{y}$-intercept and they decrease in the following order: $\mathrm{EE}_{2}(18.9 \mathrm{~J} / \mathrm{mol}), \mathrm{E}_{2}(13.4 \mathrm{~J} / \mathrm{mol}), \mathrm{E}_{1}(-42.1 \mathrm{~J} / \mathrm{mol}), \mathrm{E}_{3}(-55.9$ $\mathrm{J} / \mathrm{mol})$ and phenol $(-116.3 \mathrm{~J} / \mathrm{mol})$. The reaction rates increase with activation entropies and they decrease as the activation enthalpies increase. This means that HRP-OXC is entropy-driven and enthalpy retarded.

A higher (i.e. more positive) activation entropy value implies a more flexible binding structure in the active site pocket. Before substrate binding, phenolics are coated with water molecules so as to maximize hydrogen bonding and decrease entropy (Frank and Evans, 1945). The active site also hosts a rigid and ordered structure because of the interaction of the residues, the heme, and the solute matrix in the substrate access channel (Vlasits et al., 2010). Thus, the solution system starts at low entropy. When the substrate enters the active pocket, the solvation shell (i.e. water molecules) is lost and active site interactions are formed. These dynamics help shed light on the observations made in this study. For example, the phenol had a lower reaction rate constant and a larger binding distance, compared to the four hormones. It is hypothesized that these higher reaction rates are possible when chemicals move deeper into the active site 
pocket, which can destroy the solvation shell to a higher extent and may lead to the higher entropy change if new chemical bonds permit many degrees of freedom. It is possible that some hormones may move deep into the active site but not trigger the high entropy change because new chemical bonds may create rigidity. Isothermal titration calorimetry can be done in future experiments to address these ideas.

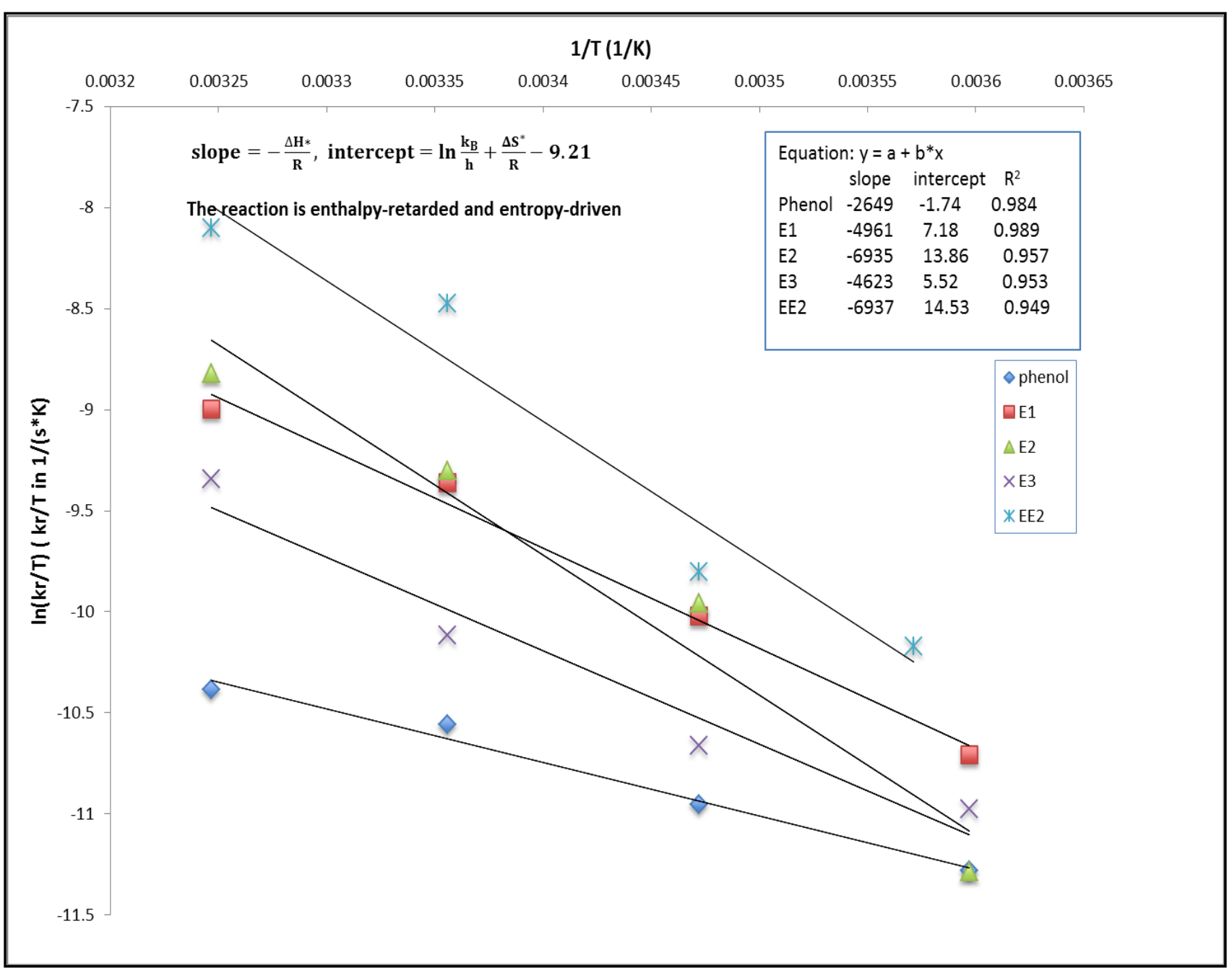

Figure 14. Determinaton of thermodynamic parameters 
The thermodynamic data generates a strong linear relationship $\left(\mathrm{R}^{2}=0.99\right)$ between enthalpy and entropy, as shown in Figure 15. Changes in enthalpy are seen to be compensated for with associated changes in entropy, it is referred to enthalpy-entropy compensation theory. This idea is generally controversial, because linearity in enthalpy-entropy relationships may be caused by artifacts (Cornish-Bowden, 2002). However, for aqueous reactions involving small molecules, there is more confidence in linear enthalpy-entropy relationships as evidence for the role of water molecules in enzymatic reactions (e.g. Lumry et al., 1970, Kinoshita, 2009, Kocherbitov and Arnebrant, 2010). Therefore, the data in this study supports the idea that water molecules play in HRP-OXC and future experiments should attempt to address this by directly measuring both enthalpy and entropy.

It is also noted that the values of the activation entropies are, in principle, related to reaction mechanisms (Stearn et al. 1939, Villa et al., 2000, Milischuk et al., 2006). Activation entropy includes two contributions, one related to a change in the rotational and translational freedom of the reacting species and a second related to interactions with the solvent. It is determined that the slowest reacting chemicals (e.g. phenol) had a negative activation entropy and that the fastest reacting hormone (e.g. $\mathrm{EE}_{2}$ ) had a positive activation entropy. This suggests that subtle electron exchange distinctions may be associated with significant kinetic implications, but we are not in a position to clarify this issue further because it is not clear what parts of these entropies are intrinsic to the electron exchange reaction and what parts are associated with solvation entropies. Fortunately, this issue can be addressed in future research with computational approaches that provide a car eful accounting for all chemical interactions that influence entropy (Kamerlin et al., 2008). 


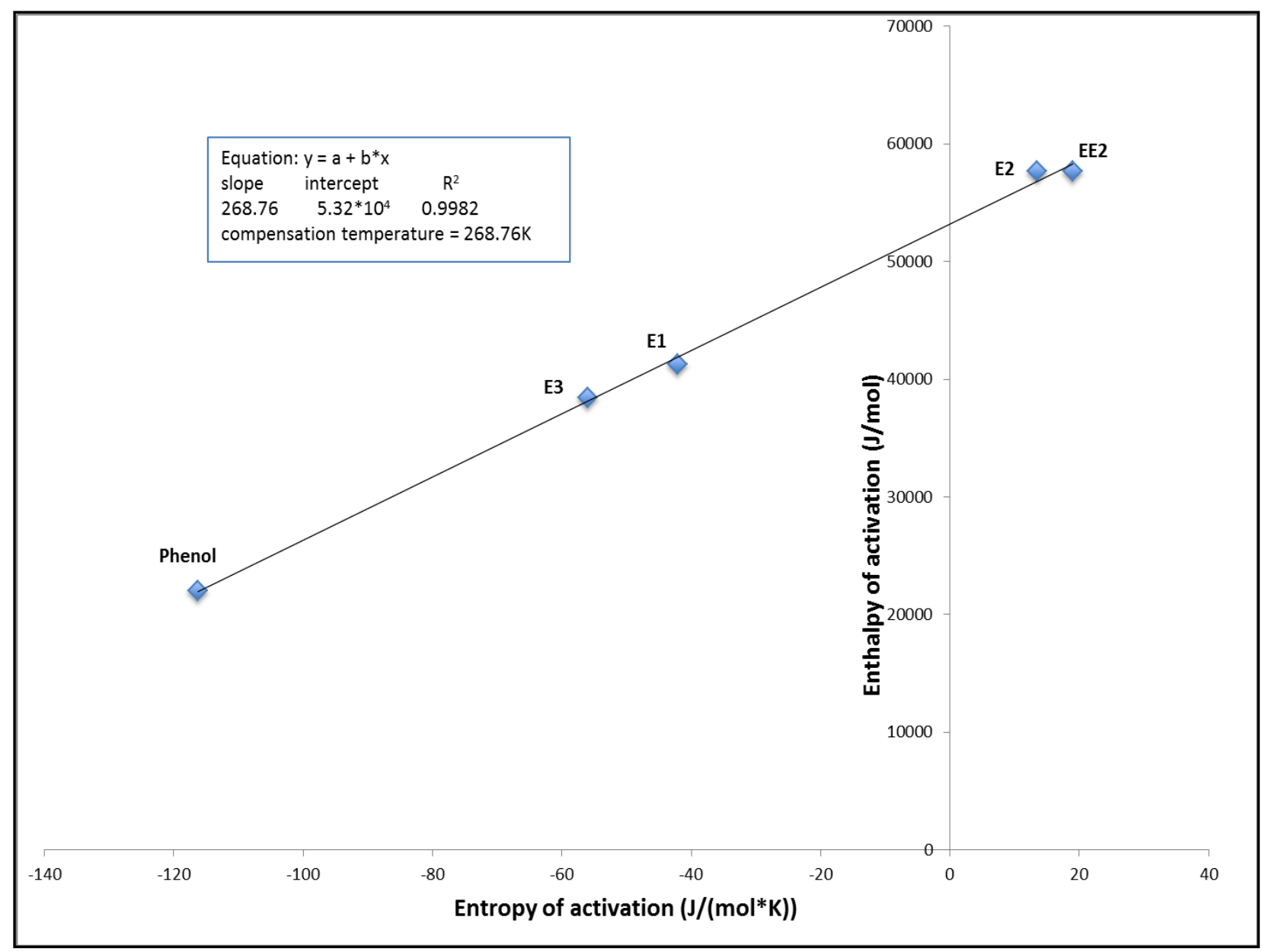

Figure 15. Linear relationship between activation enthalpy and activation entropy

\subsubsection{HRP-OXC Applied on Real Wastewater}

Figure 16 shows the phenolic substrates removal with real wastewater. 5 substrates (phenol, $E_{1}, E_{2}, E_{3}$ and $E_{2}$ ) were spiked into the second effluent water taken from the Bethel Park/South Park Municipal Authority with the concentration of 1mg/l and a corresponding HRP $(1.48 \mathrm{U} / \mathrm{ml})$ and $\mathrm{H}_{2} \mathrm{O}_{2}(40 \mu \mathrm{M})$ concentration. Within 5 minutes, the removal for all substrates exceeded $80 \% . \mathrm{EE}_{2}$ and $\mathrm{E}_{2}$ have an especially high removal rate. The removal efficiency is $\mathrm{EE}_{2}$, $\mathrm{E}_{2}, \mathrm{E}_{1}, \mathrm{E}_{3}$, phenol, in decreasing order, which is in accordance with the relative reactivity in 
synthetic water. This indicates that the HRP oxidative coupling reaction is relatively stable with municipal wastewater effluent and both the intrinsic substrate reactivity and its affinity to the HRP enzyme play the determining role.

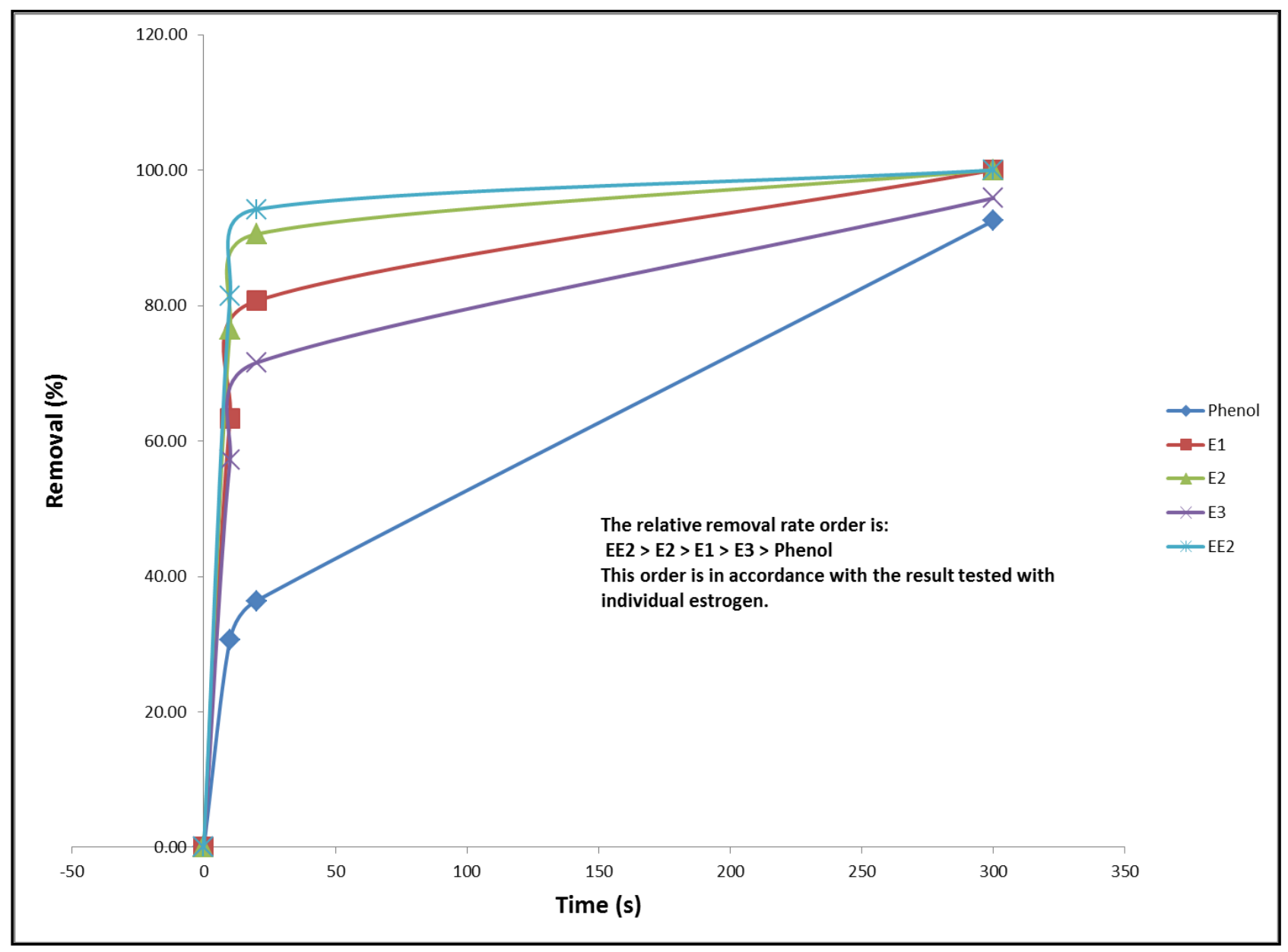

Figure 16. HRP-OXC applied on WWTP secondary effluent water 


\subsection{SUMMARY, CONCLUSIONS AND FUTURE WORK}

\subsection{SUMMARY AND CONCLUSIONS}

In this study, various factors affecting substrate reactivity during HRP-OXC of phenolic chemicals were evaluated.

The reactions were determined to be first order with respect to phenolic concentration. Reaction rate constants $\left(\mathrm{k}_{\mathrm{r}}\right)$ were determined to be in the increasing order for phenol, $E_{3}, E_{1}, E_{2}$ and EE2. Structurally similar chemicals can be oxidatively polymerized at very different rates.

$>$ Reaction rates were demonstrated not diffusion-limited, but instead controlled by enzyme-substrate interactions.

$>$ Binding energy and distance both explain why phenol is removed more slowly than the four hormones, but other contributing factors appear to influence reaction rates. Molecular volume of the substrates did not impact reaction rates in this study, likely because the HRP active site is large enough to accommodate all of the studied phenolic chemicals.

$>$ Thermodynamic parameters were evaluated and positive activation enthalpies and negative activation entropies were obtained. HRP-OXC is entropy-driven and enthalpy retarded. 
Water might play a role in taking part in the HRP-OXC, as suggested by the strong enthalpy-entropy compensation phenomenon.

\subsection{FUTURE WORK}

Future efforts should be implemented with the following focuses:

$>$ Measuring the actual enthalpy and entropy change with a calorimeter. Meanwhile, solvent effect and the reaction condition should be taken into consideration when conducting the modeling simulation.

$>$ Carry out OXC with real wastewater and further evaluate the influence of constituent matrix, eg. natural organic matter (NOM), salt concentration, on the enzyme use dosage, the coupling product characterization and distribution, and the reaction kinetics.

D Investigate the practical ways to employ and couple HRP-OXC in real wastewater treatment plants. Engineearing applications to be studied include applying the HRP-OXC for treating sidestream from sludge digesters; Immobilizing HPR and implementing HRP-OXC on secondary effluent water and followed by filtration.

$>$ Evaluate the feasibility of HRP-OXC for point source treatments, eg. Urine, as this strategy has the potential to reduce chemical and energy demand. 
APPENDIX A

HPLC OUTPUT DATA FOR KINETICS AND THERMODYNAMICS 
Table 9. Phenol kinetics at $25^{\circ} \mathrm{C}$

\section{PHENOL}

Phenol calibration curve data

Phenol

concentration area

$(\mu \mathrm{M})(\mathrm{x})$

(y)

$6 \quad 94.3$

$5 \quad 79.1$

$4 \quad 63.4$

$3 \quad 46.3$

$0 \quad 0$

Calibration curve: $\mathrm{y}=15.74 \mathrm{x}$

\section{PHENOL KINETIC REACTION AT $25^{\circ} \mathrm{C}$}

Stock

solution

volume

$1.3 \mathrm{ml}$

$1.0 \mathrm{ml}$

$0.6 \mathrm{ml}$

$0.3 \mathrm{ml}$

$0.2 \mathrm{ml}$ peak

time time

(s) (min)

\section{area}

9.139

9.139

9.16

9.165

9.15

9.166

9.171

9.188

9.187

9.205

9.21

9.225

9.23

9.241

9.221

9.215

9.206

9.231

9.221

9.218 area

385.98

369.285

357.315

319.515

296.31

281.925

269.325

192.255

176.19

166.53

158.025

95.97

87.885

82.005

76.965

63.945

59.85

55.44 heigh

35

32.4

31.1

30.1

26.9

24.9

23.7

22.6

16.1

14.8

14

13.2

8.1

7.4

6.9

6.5

5.4

5.1

4.7 width

0.17

0.18

0.17

0.17

0.18

0.17

0.18

0.18

0.18

0.18

0.18

0.18

0.18

0.18

0.17

0.17

0.17

0.17

0.17

0.17
Conc. $(\mu \mathrm{M})$

26.330

24.522

23.462

22.701

20.300

18.825

17.911

17.111

12.214

11.194

10.580

10.040

6.097

5.584

5.210

4.890

4.063

3.802

3.522 va $(\mu \mathrm{M} / \mathrm{s}) \quad \log \mathrm{A} \quad \log v a \quad 1 / \mathrm{s} \quad 1 / \mathrm{v}$ \begin{tabular}{llll|l|l}
0.190 & 1.420 & -0.722 & 0.038 & 5.268
\end{tabular}

$$
0.155
$$

$1.307-0.810$

$0.049 \quad 6.460$

\begin{tabular}{l|llll}
0.107 & 1.087 & -0.970 & 0.082 & 9.331
\end{tabular}

0.054

$0.785 \quad-1.268$

$0.164 \quad 18.541$

0.027

$0.609-1.564$

$0.246 \quad 36.607$ 
Table 10. Phenol reaction at different temperatures

\begin{tabular}{|c|c|c|c|c|c|c|c|c|c|c|c|}
\hline \multirow[b]{2}{*}{ Temperature } & \multirow[b]{2}{*}{$\begin{array}{l}\text { Stock solution } \\
\text { volume }\end{array}$} & \multirow[b]{2}{*}{$\begin{array}{l}\text { time } \\
\text { (s) }\end{array}$} & \multirow[b]{2}{*}{$\begin{array}{l}\text { peak time } \\
\text { (min) }\end{array}$} & \multirow[b]{2}{*}{ area } & \multirow[b]{2}{*}{ height } & \multirow[b]{2}{*}{ width } & \multirow[b]{2}{*}{ Conc. ( $\mu \mathrm{M})$} & & \\
\hline & & & & & & & & $\begin{array}{l}\text { va } \\
(\mu \mathrm{M} / \mathrm{s})\end{array}$ & $\mathrm{kr}(/ \mathrm{s})$ & $1 / T$ & $\ln (\mathrm{Kr} / \mathrm{T})$ \\
\hline \multirow[t]{4}{*}{$35^{\circ} \mathrm{C}$} & $0.6 \mathrm{ml}$ & 0 & 9.214 & 191.31 & 16.1 & 0.17 & 10.907 & 0.090 & 0.010 & 0.003 & 10.384 \\
\hline & & 10 & 9.217 & 172.515 & 14.5 & 0.17 & 9.836 & & & & \\
\hline & & 20 & 9.225 & 159.6 & 13.4 & 0.18 & 9.099 & & & & \\
\hline & & 30 & 9.192 & 146.895 & 12.4 & 0.17 & 8.375 & & & & \\
\hline \multirow[t]{4}{*}{$25^{\circ} \mathrm{C}$} & $0.6 \mathrm{ml}$ & 0 & 9.205 & 192.255 & 16.1 & 0.18 & 10.961 & 0.073 & 0.008 & 0.003 & 10.556 \\
\hline & & 10 & 9.21 & 176.19 & 14.8 & 0.18 & 10.045 & & & & \\
\hline & & 20 & 9.225 & 166.53 & 14 & 0.18 & 9.494 & & & & \\
\hline & & 30 & 9.233 & 158.025 & 13.2 & 0.18 & 9.009 & & & & \\
\hline \multirow[t]{4}{*}{$15^{\circ} \mathrm{C}$} & $0.6 \mathrm{ml}$ & 0 & 9.215 & 190.68 & 16.1 & 0.17 & 10.871 & 0.047 & 0.005 & 0.003 & 10.952 \\
\hline & & 10 & 9.263 & 180.075 & 15.1 & 0.18 & 10.267 & & & & \\
\hline & & 20 & 9.272 & 174.09 & 14.6 & 0.18 & 9.925 & & & & \\
\hline & & 30 & 9.267 & 164.535 & 13.8 & 0.18 & 9.381 & & & & \\
\hline \multirow[t]{4}{*}{$5^{\circ} \mathrm{C}$} & $0.6 \mathrm{ml}$ & 0 & 9.251 & 191.1 & 16.1 & 0.17 & 10.895 & 0.033 & 0.004 & 0.004 & 11.281 \\
\hline & & 10 & 9.249 & 184.065 & 15.5 & 0.18 & 10.494 & & & & \\
\hline & & 20 & 9.236 & 179.55 & 15.1 & 0.17 & 10.237 & & & & \\
\hline & & 30 & 9.225 & 176.295 & 14.9 & 0.18 & 10.051 & & & & \\
\hline
\end{tabular}


Table 11. Estrone kinetics at $25^{\circ} \mathrm{C}$

\section{ESTRONE}

estrone calibration curve data

estrone

concentration

( $\mu \mathrm{M})(\mathrm{x})$

area (y)

$5 \quad 162.5$

$4 \quad 98.4$

$3 \quad 66.5$

$2 \quad 40.8$

$0 \quad 0$

Calibration curve: $\mathrm{y}=27.54 .1 \mathrm{x}$

Stock

solution

volume

$0.5 \mathrm{ml}$

$0.4 \mathrm{ml}$

$0.3 \mathrm{ml}$

$0.2 \mathrm{ml}$ peak

time

time $(\mathrm{s}) \quad(\mathrm{min})$

cali

12.532

12.509

$10 \quad 12.507$

20

12.49

cali 12.555

$0 \quad 12.52$

$10 \quad 12.527$

$20 \quad 12.522$

cali

12.54

$0 \quad 12.56$

$10 \quad 12.558$

20

cali

12.545

12.567

12.57

12.59

12.59
12.591 area height width

162.5

$\begin{array}{ll}9.4 & 0.2672\end{array}$

$\begin{array}{lll}185.1 & 10.8 & 0.2655\end{array}$

145.5

$\begin{array}{ll}8.5 & 0.2665\end{array}$

$\begin{array}{ll}6.5 & 0.2655\end{array}$

$\begin{array}{ll}5.7 & 0.2665\end{array}$

$\begin{array}{ll}3.9 & 0.2661\end{array}$

$3 \quad 0.2676$

$3.4 \quad 0.2665$

$3.9 \quad 0.2667$

$\begin{array}{ll}4.4 & 0.2673\end{array}$

$2.6 \quad 0.2685$

20.2666

$\begin{array}{ll}2.4 & 0.2693\end{array}$

$\begin{array}{ll}2 & 0.2679\end{array}$

$\begin{array}{ll}1.5 & 0.2685\end{array}$

1.10 .2576 va

5.900

6.721

5.283

4.016

3.573

2.436

1.855

2.146

2.415

2.741

1.612

1.278

1.481

1.245

0.937

0.708 va

0.151

$0.848 \quad-0.8211$

0.1417

6.6236

0.061

$0.408 \quad-1.2147$

$0.3909 \quad 16.393$

0.119

$0.459-0.926$

$0.3474 \quad 8.4339$

0.032

$0.117 \quad-1.4894$

$0.7647 \quad 30.858$ 
Table 12. Estrone reaction at different temperatures

\begin{tabular}{|c|c|c|c|c|c|c|c|}
\hline Temperature & time $(\mathrm{s})$ & area & Conc $(\mu M)$ & $\operatorname{va}(\mu \mathrm{M} / \mathrm{s})$ & $\mathrm{kr}(/ \mathrm{s})$ & $1 / \mathrm{T}$ & $\ln (\mathrm{kr} / \mathrm{T})$ \\
\hline \multirow[t]{3}{*}{$35 C$} & 0 & 103.425 & 2.069 & 0.044 & 0.038 & 0.003 & -9.000 \\
\hline & 10 & 81.48 & 1.630 & & & & \\
\hline & 20 & 63.735 & 1.275 & & & & \\
\hline \multirow[t]{3}{*}{$25 C$} & 0 & 101.115 & 2.022 & 0.029 & 0.026 & 0.003 & -9.363 \\
\hline & 10 & 88.62 & 1.772 & & & & \\
\hline & 20 & 72.24 & 1.445 & & & & \\
\hline \multirow[t]{3}{*}{$15 C$} & 0 & 88.725 & 1.775 & 0.013 & 0.013 & 0.003 & -10.019 \\
\hline & 10 & 76.02 & 1.520 & & & & \\
\hline & 20 & 81.375 & 1.628 & & & & \\
\hline \multirow[t]{3}{*}{$5 C$} & 0 & 86.1 & 1.722 & 0.006 & 0.006 & 0.004 & -10.706 \\
\hline & 10 & 86.73 & 1.735 & & & & \\
\hline & 20 & 80.115 & 1.602 & & & & \\
\hline
\end{tabular}


Table 13. Estradiol kinetics at $25^{\circ} \mathrm{C}$

\section{ESTRADIOL}

Estradiol calibration curve data

Estradiol

concentration area

$(\mu \mathrm{M})(\mathrm{x})$

$$
\text { (y) }
$$

$$
\begin{array}{ll}
5 & 210.7
\end{array}
$$

$4 \quad 170.4$

$3 \quad 147$

$2 \quad 101.4$

$0 \quad 0$

Calibration curve: $\mathrm{y}=44.05 \mathrm{x}$

\begin{tabular}{|c|c|c|c|c|c|c|c|c|c|c|c|}
\hline $\begin{array}{l}\text { Stock solution } \\
\text { volume }\end{array}$ & $\begin{array}{l}\text { time } \\
\text { (s) }\end{array}$ & $\begin{array}{l}\text { peak } \\
\text { time } \\
\text { (min) }\end{array}$ & area & height & width & Conc. $(\mu \mathrm{M})$ & va $(\mu \mathrm{M} / \mathrm{s})$ & $\log A$ & log va & $1 / \mathrm{s}$ & $1 / v$ \\
\hline \multirow[t]{3}{*}{$0.5 \mathrm{ml}$} & 0 & 7.428 & 284.6 & 21.1 & 0.161 & 6.461 & 0.130 & 0.676 & -0.886 & 0.147 & 7.686 \\
\hline & 10 & 7.429 & 206.535 & 18.9 & 0.160 & 4.689 & & & & & \\
\hline & 20 & 7.429 & 164.955 & 15.1 & 0.161 & 3.745 & & & & & \\
\hline \multirow[t]{2}{*}{$0.4 \mathrm{ml}$} & 0 & 7.485 & 179.4 & 18.4 & 0.163 & 4.073 & 0.075 & 0.476 & -1.124 & 0.234 & 13.302 \\
\hline & 10 & 7.48 & 134.295 & 11.4 & 0.170 & 3.049 & & & & & \\
\hline \multirow[t]{3}{*}{$0.3 \mathrm{ml}$} & 0 & 7.434 & 174 & 16.7 & 0.161 & 3.950 & 0.081 & 0.462 & -1.092 & 0.241 & 12.365 \\
\hline & 10 & 7.446 & 125.475 & 11.5 & 0.161 & 2.848 & & & & & \\
\hline & 20 & 7.465 & 99.015 & 94.3 & 9.000 & 2.248 & & & & & \\
\hline \multirow[t]{3}{*}{$0.1 \mathrm{ml}$} & 0 & 7.481 & 65.1 & 4.4 & 0.179 & 1.478 & 0.030 & 0.035 & -1.527 & 0.644 & 33.613 \\
\hline & 10 & 7.486 & 47.25 & 4.3 & 0.182 & 1.073 & & & & & \\
\hline & 20 & 7.491 & 47.145 & 3.4 & 0.194 & 1.070 & & & & & \\
\hline
\end{tabular}

\section{ESTRADIOL KINETIC REACTION AT $25^{\circ} \mathrm{C}$}


Table 14. Estradiol reaction at different temperatures

\begin{tabular}{|c|c|c|c|c|c|c|c|c|c|c|c|}
\hline Temperature & $\begin{array}{l}\text { Stock solution } \\
\text { volume }\end{array}$ & $\begin{array}{l}\text { time } \\
\text { (s) }\end{array}$ & $\begin{array}{l}\text { peak time } \\
\text { (min) }\end{array}$ & area & height & width & Conc. $(\mu \mathrm{M})$ & $\begin{array}{l}\text { va } \\
(\mu \mathrm{M} / \mathrm{s})\end{array}$ & $\mathrm{kr}(/ \mathrm{s})$ & $1 / \mathrm{T}$ & $\ln (\mathrm{Kr} / \mathrm{T})$ \\
\hline \multirow[t]{2}{*}{$35 \mathrm{C}$} & $0.5 \mathrm{ml}$ & 0 & 7.469 & 301.4202 & 28.5 & 0.166 & 5.480 & 0.283 & 0.051 & 0.003 & -8.704 \\
\hline & & 10 & 7.488 & 145.845 & 13.2 & 0.163 & 2.652 & & & & \\
\hline \multirow[t]{3}{*}{$25 \mathrm{C}$} & $0.5 \mathrm{ml}$ & 0 & 7.428 & 284.6 & 21.1 & 0.161 & 5.175 & 0.142 & 0.027 & 0.003 & -9.303 \\
\hline & & 10 & 7.429 & 206.535 & 18.9 & 0.160 & 3.755 & & & & \\
\hline & & 20 & 7.429 & 164.955 & 15.1 & 0.161 & 2.999 & & & & \\
\hline \multirow[t]{2}{*}{$15 \mathrm{C}$} & $0.5 \mathrm{ml}$ & 0 & 7.479 & 253.575 & 23.5 & 0.163 & 4.610 & 0.071 & 0.015 & 0.003 & -9.840 \\
\hline & & 10 & 7.468 & 214.305 & 19.9 & 0.163 & 3.896 & & & & \\
\hline \multirow[t]{3}{*}{$5 C$} & $0.5 \mathrm{ml}$ & 0 & 7.463 & 203.116 & 19.6 & 0.162 & 3.693 & 0.015 & 0.004 & 0.004 & -11.167 \\
\hline & & 10 & 7.471 & 161.175 & 14.7 & 0.163 & 2.930 & & & & \\
\hline & & 20 & 7.478 & 187.005 & 16.9 & 0.162 & 3.400 & & & & \\
\hline
\end{tabular}


Table 15. Estriol kinetics at $25^{\circ} \mathrm{C}$

\section{ESTRIOL}

Estriol calibration curve data

Estriol

concentration

$\begin{array}{rrr}(\mu \mathrm{M})(\mathrm{x}) & & \text { area }(\mathrm{y}) \\ 5 & 323.1 \\ 4 & 260.6 \\ 3 & 210 \\ 2 & 145.4 \\ 0 & 0\end{array}$

Calibration curve: $y=64.14 x$

\section{ESTRIOL KINETIC REACTION AT $25^{\circ} \mathrm{C}$}

\begin{tabular}{|c|c|c|c|c|c|c|c|c|c|c|}
\hline time (s) & $\begin{array}{l}\text { peak } \\
\text { time } \\
\text { (min) }\end{array}$ & area & height & width & Conc. $(\mu \mathrm{M})$ & va $(\mu \mathrm{M} / \mathrm{s})$ & $\log A$ & log va & $1 / \mathrm{s}$ & $1 / v$ \\
\hline 0 & 2.049 & 75.705 & 19.9 & 0.056 & 1.180 & 0.009 & 0.072 & -2.046 & 0.847 & 11.111 \\
\hline 10 & 2.05 & 70.56 & 16.4 & 0.061 & 1.100 & & & & & \\
\hline 20 & 2.049 & 64.155 & 14.3 & 0.062 & 1.000 & & & & & \\
\hline 30 & 2.051 & 61.425 & 13.4 & 0.065 & 0.958 & & & & & \\
\hline 0 & 2.048 & 143.01 & 39.1 & 0.053 & 2.230 & 0.026 & 0.348 & -1.587 & 0.449 & 38.662 \\
\hline 10 & 2.048 & 125.16 & 34.3 & 0.053 & 1.951 & & & & & \\
\hline 20 & 2.048 & 109.83 & 30.1 & 0.053 & 1.712 & & & & & \\
\hline 30 & 2.047 & 100.065 & 27.4 & 0.054 & 1.560 & & & & & \\
\hline 0 & 2.049 & 278.985 & 71.5 & 0.057 & 4.350 & 0.046 & 0.638 & -1.337 & 0.230 & 21.739 \\
\hline 10 & 2.049 & 229.11 & 58.6 & 0.057 & 3.572 & & & & & \\
\hline 20 & 2.05 & 219.975 & 54.8 & 0.058 & 3.430 & & & & & \\
\hline 30 & 2.049 & 205.485 & 49.8 & 0.058 & 3.204 & & & & & \\
\hline 0 & 2.046 & 416.115 & 123.3 & 0.053 & 6.488 & 0.072 & 0.812 & -1.142 & 0.154 & 13.852 \\
\hline 10 & 2.049 & 379.89 & 105.6 & 0.053 & 5.923 & & & & & \\
\hline 20 & 2.047 & 323.505 & 96.8 & 0.054 & 5.044 & & & & & \\
\hline 30 & 2.047 & 311.325 & 87.6 & 0.055 & 4.854 & & & & & \\
\hline
\end{tabular}


Table 16. Estriol reaction at different temperatures

\begin{tabular}{|c|c|c|c|c|c|c|c|c|c|c|}
\hline Temperature & $\begin{array}{l}\text { time } \\
\text { (s) }\end{array}$ & $\begin{array}{l}\text { peak time } \\
\text { (min) }\end{array}$ & area & height & width & $\begin{array}{l}\text { Conc. } \\
\text { ( } \mu \mathrm{M})\end{array}$ & $\begin{array}{l}\text { va } \\
(\mu \mathrm{M} / \mathrm{s})\end{array}$ & $\mathrm{kr}(/ \mathrm{s})$ & $1 / \mathrm{T}$ & $\ln (\mathrm{Kr} / \mathrm{T})$ \\
\hline \multirow[t]{4}{*}{35} & 0 & 2.044 & 408.6 & 102.1 & 0.06 & 6.370 & $1.18 \mathrm{E}-01$ & 2.69E-02 & 0.00325 & -9.345 \\
\hline & 10 & 2.044 & 332.6 & 82.4 & 0.06 & 5.186 & & & & \\
\hline & 20 & 2.044 & 284.5 & 68.9 & 0.06 & 4.436 & & & & \\
\hline & 30 & 2.045 & 243 & 59.4 & 0.06 & 3.789 & & & & \\
\hline \multirow[t]{4}{*}{25} & 0 & 2.044 & 396.3 & 100.8 & 0.06 & 6.179 & 0.054 & $1.20 \mathrm{E}-02$ & 0.00336 & -10.118 \\
\hline & 10 & 2.048 & 361.8 & 85.8 & 0.06 & 5.641 & & & & \\
\hline & 20 & 2.044 & 308.1 & 77.9 & 0.06 & 4.804 & & & & \\
\hline & 30 & 2.044 & 296.5 & 71.5 & 0.06 & 4.623 & & & & \\
\hline \multirow[t]{4}{*}{15} & 0 & 2.044 & 392.5 & 91.2 & 0.06 & 6.119 & 0.026 & $6.74 \mathrm{E}-03$ & 0.00347 & -10.662 \\
\hline & 10 & 2.046 & 375.6 & 101.4 & 0.06 & 5.856 & & & & \\
\hline & 20 & 2.044 & 353.1 & 86.3 & 0.06 & 5.505 & & & & \\
\hline & 30 & 2.045 & 340.7 & 82.1 & 0.06 & 5.312 & & & & \\
\hline \multirow[t]{4}{*}{5} & 0 & 2.048 & 398.3 & 116.9 & 0.05 & 6.210 & 0.021 & 4.76E-03 & 0.00360 & -10.975 \\
\hline & 10 & 2.048 & 385.1 & 108.5 & 0.05 & 6.004 & & & & \\
\hline & 20 & 2.049 & 377.9 & 107.7 & 0.05 & 5.892 & & & & \\
\hline & 30 & 2.05 & 359.4 & 362.6 & 102.30 & 0.055 & & & & \\
\hline
\end{tabular}


Table $17.17 \alpha$-ethinylestradiol kinetics at $25^{\circ} \mathrm{C}$

\section{7 $\alpha$-ETHINYLESTRADIOL}

$17 \alpha$-Ethinylestradiol calibration curve data

$17 \alpha$-Ethinylestradiol

concentration $(\mu \mathrm{M}) \quad$ area

$(x)$

(y)

$5 \quad 173.4$

$4 \quad 193.1$

$3 \quad 122.1$

291.2

$0 \quad 0$

Calibration curve: $y=40.63$

$17 \alpha$-ETHINYLESTRADIOL REACTION KINETICS AT $25^{\circ} \mathrm{C}$

\begin{tabular}{|c|c|c|c|c|c|c|c|c|c|c|c|}
\hline $\begin{array}{l}\text { Stock } \\
\text { solution }\end{array}$ & $\begin{array}{l}\text { time } \\
\text { (s) }\end{array}$ & $\begin{array}{l}\text { peak } \\
\text { time } \\
\text { (min) }\end{array}$ & area & height & width & Conc. $(\mu \mathrm{M})$ & $\begin{array}{l}\text { va } \\
(\mu \mathrm{M} / \mathrm{s})\end{array}$ & $\log A$ & log va & $1 / \mathrm{s}$ & $1 / v$ \\
\hline \multirow[t]{2}{*}{$0.5 \mathrm{ml}$} & 0 & 10.965 & 237.09 & 14.9 & 0.23 & 5.850 & 0.298 & 0.767 & -0.526 & 0.163 & 3.354 \\
\hline & 10 & 10.963 & 116.235 & 7.3 & 0.24 & 2.868 & & & & & \\
\hline \multirow[t]{3}{*}{$0.4 \mathrm{ml}$} & 0 & 10.961 & 279.3 & 17.4 & 0.24 & 6.891 & 0.342 & 0.838 & -0.465 & 0.138 & 2.920 \\
\hline & 10 & 10.958 & 140.49 & 8.8 & 0.23 & 3.466 & & & & & \\
\hline & 20 & 10.949 & 78.855 & 4.9 & 0.24 & 1.946 & & & & & \\
\hline \multirow[t]{3}{*}{$0.3 \mathrm{ml}$} & 0 & 10.968 & 148.89 & 9.8 & 0.24 & 3.674 & 0.189 & 0.565 & -0.724 & 0.259 & 5.302 \\
\hline & 10 & 10.954 & 72.45 & 4.6 & 0.23 & 1.788 & & & & & \\
\hline & 20 & 10.954 & 111.3 & 6.9 & 0.24 & 2.746 & & & & & \\
\hline \multirow[t]{3}{*}{$0.2 \mathrm{ml}$} & 0 & 10.941 & 118.44 & 7.4 & 0.24 & 2.922 & 0.149 & 0.466 & -0.827 & 0.326 & 6.719 \\
\hline & 10 & 10.942 & 197.715 & 12 & 0.24 & 4.878 & & & & & \\
\hline & 20 & 10.93 & 77.07 & 4.8 & 0.23 & 1.902 & & & & & \\
\hline \multirow[t]{2}{*}{$0.1 \mathrm{ml}$} & 0 & 10.94 & 63 & 4.3 & 0.24 & 1.554 & 0.095 & 0.192 & -1.021 & 0.613 & 10.489 \\
\hline & 10 & 10.95 & 24.36 & 2.7 & 0.24 & 0.601 & & & & & \\
\hline
\end{tabular}


Table 18. 17 $\alpha$-ethinylestradiol reaction at different temperatures

\begin{tabular}{|c|c|c|c|c|c|c|c|c|c|c|}
\hline Temperature & $\begin{array}{l}\text { time } \\
\text { (s) }\end{array}$ & $\begin{array}{l}\text { peak } \\
\text { time } \\
\text { (min) }\end{array}$ & area & height & width & $\begin{array}{l}\text { Conc. } \\
(\mu \mathrm{M})\end{array}$ & $\begin{array}{l}\text { va } \\
(\mu \mathrm{M} / \mathrm{s})\end{array}$ & $\mathrm{kr}(/ \mathrm{s})$ & $1 / \mathrm{T}$ & $\ln (\mathrm{Kr} / \mathrm{T})$ \\
\hline \multirow[t]{3}{*}{$35^{\circ} \mathrm{C}$} & 0 & 10.923 & 117 & 6.2 & 0.299 & 1.671 & 0.103 & 0.093 & 0.00325 & -8.103 \\
\hline & 10 & 10.887 & 48.5 & 2.7 & 0.281 & 0.693 & & & & \\
\hline & 20 & 10.906 & 26.3 & 1.5 & 0.276 & 0.376 & & & & \\
\hline \multirow[t]{3}{*}{$25^{\circ} \mathrm{C}$} & 0 & 10.98 & 258.2 & 12.6 & 0.329 & 3.689 & & & & \\
\hline & 10 & 11.016 & 157.3 & 7.6 & 0.334 & 2.247 & 0.151 & 0.062 & 0.00336 & -8.474 \\
\hline & 20 & 11.002 & 134.5 & 7 & 0.306 & 1.921 & & & & \\
\hline \multirow[t]{3}{*}{$15^{\circ} \mathrm{C}$} & 0 & 10.843 & 78.6 & 4.5 & 0.274 & 1.123 & & & & \\
\hline & 10 & 10.802 & 83.6 & 4.9 & 0.265 & 1.194 & & & & \\
\hline & 20 & 10.811 & 62.9 & 3.8 & 0.263 & 0.899 & 0.012 & 0.016 & 0.00347 & -9.804 \\
\hline \multirow[t]{3}{*}{$5^{\circ} \mathrm{C}$} & 0 & 10.773 & 187.6 & 11.6 & 0.251 & 2.680 & & & & \\
\hline & 10 & 10.767 & 168.7 & 10.6 & 0.249 & 2.410 & & & & \\
\hline & 20 & 10.801 & 162.3 & 10 & 0.252 & 2.319 & 0.019 & 0.011 & 0.00357 & -10.169 \\
\hline
\end{tabular}


Table 19. WWTP secondary effluent water kinetic data

PHENOL

\begin{tabular}{ccccccc|c|} 
time & peak time $(\mathrm{min})$ & area & height & width & Conc $(\mu \mathrm{M})$ & $\begin{array}{c}\text { Phenol } \\
\text { removal }\end{array}$ \\
0 & 3.018 & 72.9 & 15.6 & 0.072 & 4.631512071 & $0.00 \%$ \\
10 & 3.024 & 63.1 & 13.7 & 0.0711 & 4.008894536 & $30.70 \%$ \\
20 & 3.024 & 57.9 & 12.5 & 0.0714 & 3.678526048 & $36.41 \%$ \\
300 & 3.025 & 6.8 & 1.2 & 0.0829 & 0.43202033 & $92.53 \%$ \\
1800 & & 0 & 6 & & 0 & $100.00 \%$ \\
ESTRONE & & & & & & &
\end{tabular}

ESTRONE

$\begin{array}{cccccccc}\text { time } & \text { peak time }(\mathrm{min}) & \text { area } & \text { height } & \text { width } & \text { Conc }(\mu \mathrm{M}) & \begin{array}{c}\text { E1 } \\ \text { removal }\end{array} \\ 0 & 12.56 & 69.4 & 3.8 & 0.2875 & 2.519879452 & 0.00 \% \\ 10 & 12.568 & 38 & 2.1 & 0.2766 & 1.379761083 & 63.33 \% \\ 20 & 12.55 & 20 & 1.1 & 0.2821 & 0.726190044 & 80.70 \% \\ 300 & & 0 & & & 0 & 100.00 \% \\ 1800 & & 0 & & & 0 & 100.00 \% \\ \text { ESTRADIOL } & & & & & & & \end{array}$

ESTRADIOL

$\begin{array}{ccccccc}\text { time } & \text { peak time } & \text { area } & \text { height } & \text { width } & \operatorname{Conc}(\mu \mathrm{M}) & \text { removal } \\ 0 & 7.479 & 198.1 & 17.4 & 0.1768 & 4.497162316 & 0.00 \% \\ 10 & 7.477 & 60.6 & 5.3 & 0.1766 & 1.375709421 & 76.54 \% \\ 20 & 7.469 & 24.4 & 2.1 & 0.179 & 0.553916005 & 90.55 \% \\ 300 & & 0 & & & 0 & 100.00 \% \\ 1800 & & 0 & & & 0 & 100.00 \%\end{array}$

\section{ESTRIOL}

$\begin{array}{ccccccc}\text { time } & \text { peak time } & \text { area } & \text { height } & \text { width } & \text { Conc }(\mu \mathrm{M}) & \text { removal } \\ 0 & 2.056 & 296.8 & 76.4 & 0.0599 & 4.478512796 & 0.00 \% \\ 10 & 2.058 & 153.6 & 38 & 0.0671 & 2.317720908 & 57.16 \% \\ 20 & 2.056 & 102 & 23.9 & 0.0643 & 1.53911154 & 71.55 \% \\ 300 & 2.023 & 14.9 & 1.8 & 0.1106 & 0.224831 & 95.84 \% \\ 1800 & & 10.7 & & & 0.161455818 & 97.02 \%\end{array}$

ETHINYLESTRADIOL

$\begin{array}{ccccccc}\text { time } & \text { peak time } & \text { area } & \text { height } & \text { width } & \text { Conc }(\mu \mathrm{M}) & \begin{array}{c}\text { EE2 } \\ \text { removal }\end{array} \\ 0 & 10.98 & 60.4 & 3.7 & 0.2573 & 1.490254133 & 0.00 \% \\ 10 & 10.982 & 18.6 & 1.1 & 0.2451 & 0.458919319 & 81.44 \% \\ 20 & 10.961 & 5.8 & 0.36 & 0.2339 & 0.143103874 & 94.21 \% \\ 300 & & 0 & & & 0 & 100.00 \% \\ 1800 & & 0 & & & 0 & 100.00 \%\end{array}$


APPENDIX B

AUTODOCK SIMULATION OUTPUT DATA AND GRAPH 
Table 20. Phenol binding conformations and energies

$\begin{array}{cccc}\text { Binding properties } & \text { Unit }(\mathrm{kcal} / \mathrm{mol}) & \text { Unit }(\mathrm{kcal} / \mathrm{mol}) & \text { Unit }(\mathrm{kcal} / \mathrm{mol}) \\ \text { binding energy } & -3.54 & -3.25 & -3.25 \\ \text { Ligand efficiency } & -0.51 & -0.46 & -0.46 \\ \text { Inhibition constant } & 2.52 \mathrm{mM} & 4.12 \mathrm{mM} & 4.14 \mathrm{mM} \\ \text { Intermol energy } & -3.84 & -3.55 & -3.55 \\ \text { Vdw sesolvation energy } & -3.81 & -3.5 & -3.53 \\ \text { Electrostatic energy } & -0.03 & -0.05 & -0.02 \\ \text { Moving ligand fixed receptor } & -3.84 & -3.55 & -3.55 \\ \text { Moving ligand moving receptor } & 0.01 & 0.0 & -0.64 \\ \text { Total internal } & 0.01 & 0.01 & 0.01 \\ \text { Ligand internal } & 0.01 & 0.01 & 0.01 \\ \text { Torsional energy } & 0.3 & 0.3 & 0.3 \\ \text { Unbound energy } & 0.01 & 0.01 & 0.01 \\ \text { Cl RMS } & 0.21 & 0.91 & 0\end{array}$


10 lowest energy conformations were selected and figures fall into the same cluster have very similar binding site.

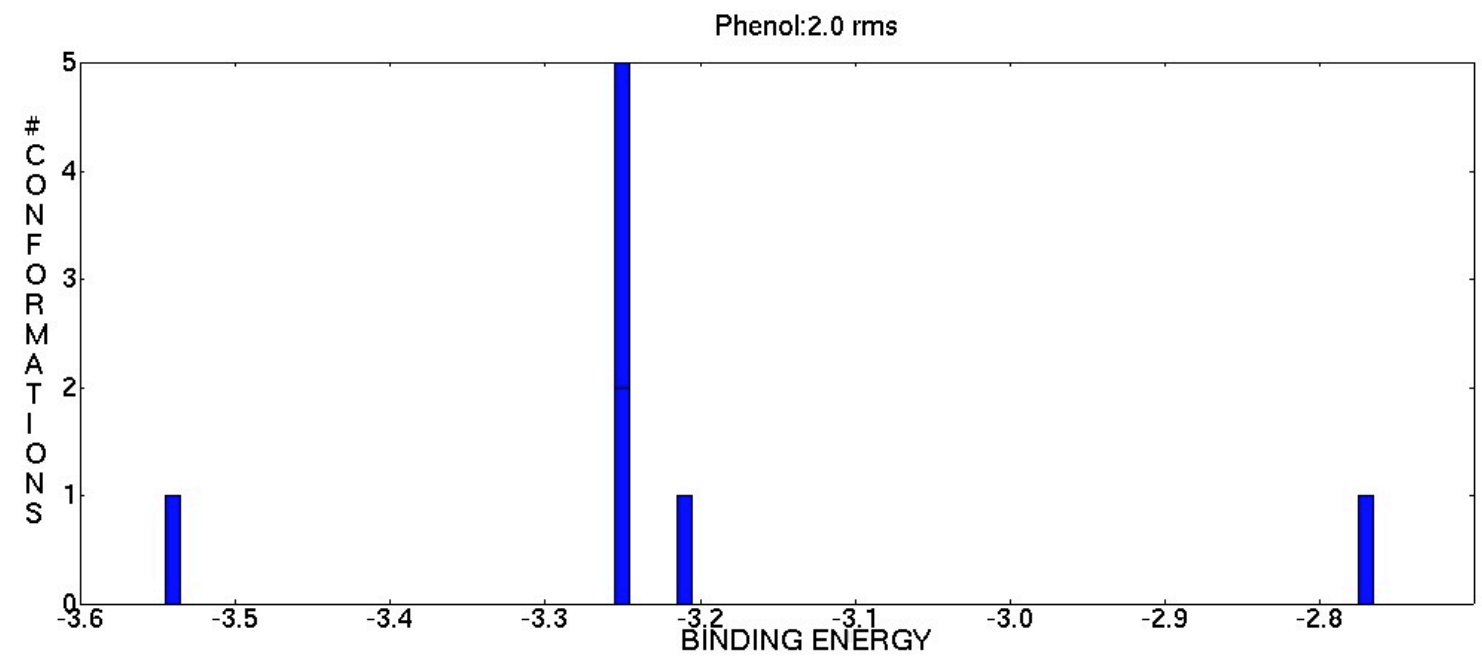

Figure 17. Phenol conformation clusters

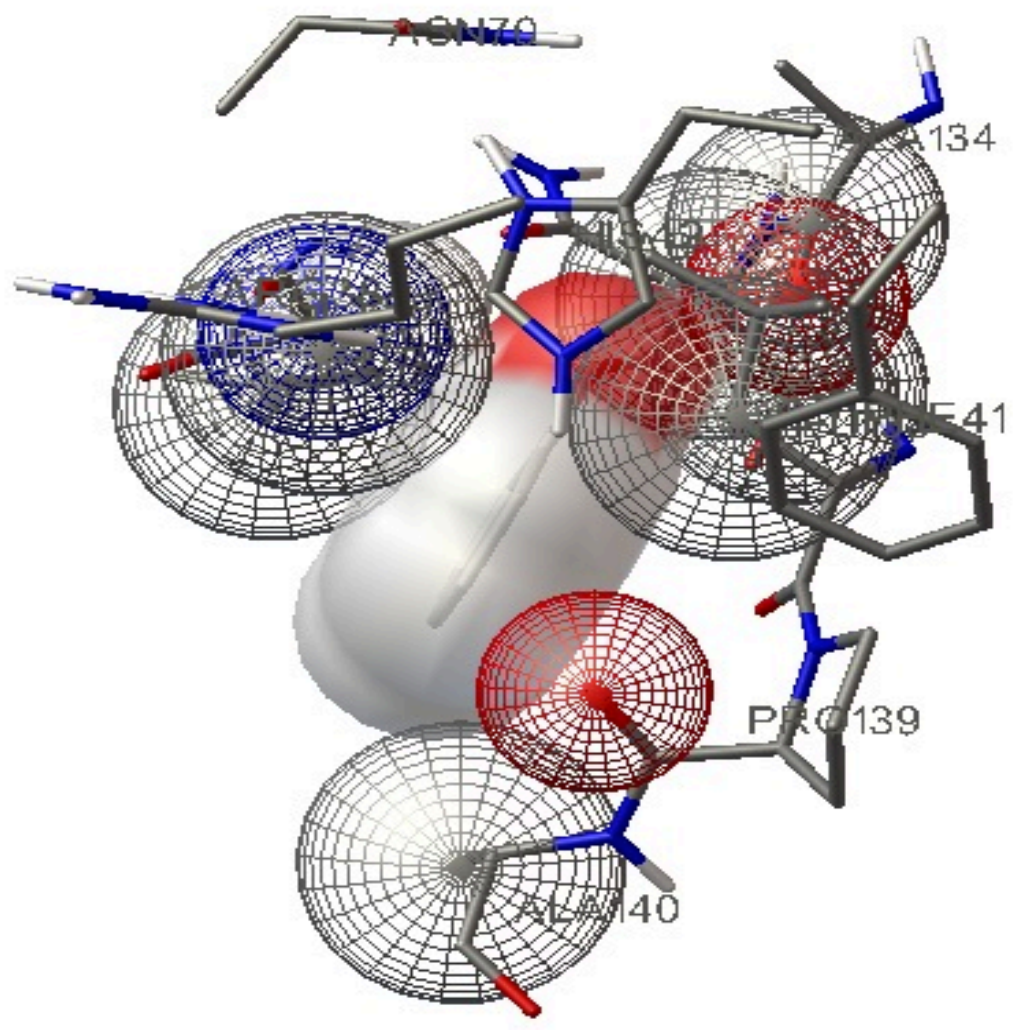

Figure 18. Interaction of phenol and relevent enzyme residues. 
Table 21. Estrone binding conformations and energies

$\begin{array}{cccc}\text { Binding properties } & \text { Unit (kcal/mol) } & \text { Unit (kcal/mol) } & \text { Unit (kcal/mol) } \\ \text { binding energy } & -7.61 & -7.47 & -7.45 \\ \text { Ligand efficiency } & -0.38 & -0.37 & -0.37 \\ \text { Inhibition constant } & 2.65 \mu \mathrm{M} & 3.36 \mu \mathrm{M} & 3.45 \mu \mathrm{M} \\ \text { Intermol energy } & -7.91 & -7.77 & -7.75 \\ \text { Vdw sesolvation energy } & -7.93 & -7.79 & -7.78 \\ \text { Electrostatic energy } & 0.03 & 0.03 & 0.03 \\ \text { Moving ligand fixed receptor } & -7.91 & -7.77 & -7.75 \\ \text { Moving ligand moving receptor } & -0.21 & -0.2 & -1.29 \\ \text { Total internal } & 0.02 & 0.02 & 0.02 \\ \text { Ligand internal } & 0.02 & 0.02 & 0.02 \\ \text { Torsional energy } & 0.3 & 0.3 & 0.3 \\ \text { Unbound energy } & 0.02 & 0.02 & 0.02 \\ \text { Cl RMS } & 0 & 0.68 & 0.32 \\ \text { Ref RMS } & 5.42 & 5.39 & 5.32\end{array}$


10 lowest energy conformations in total and figures fall into the same cluster have very similar binding site

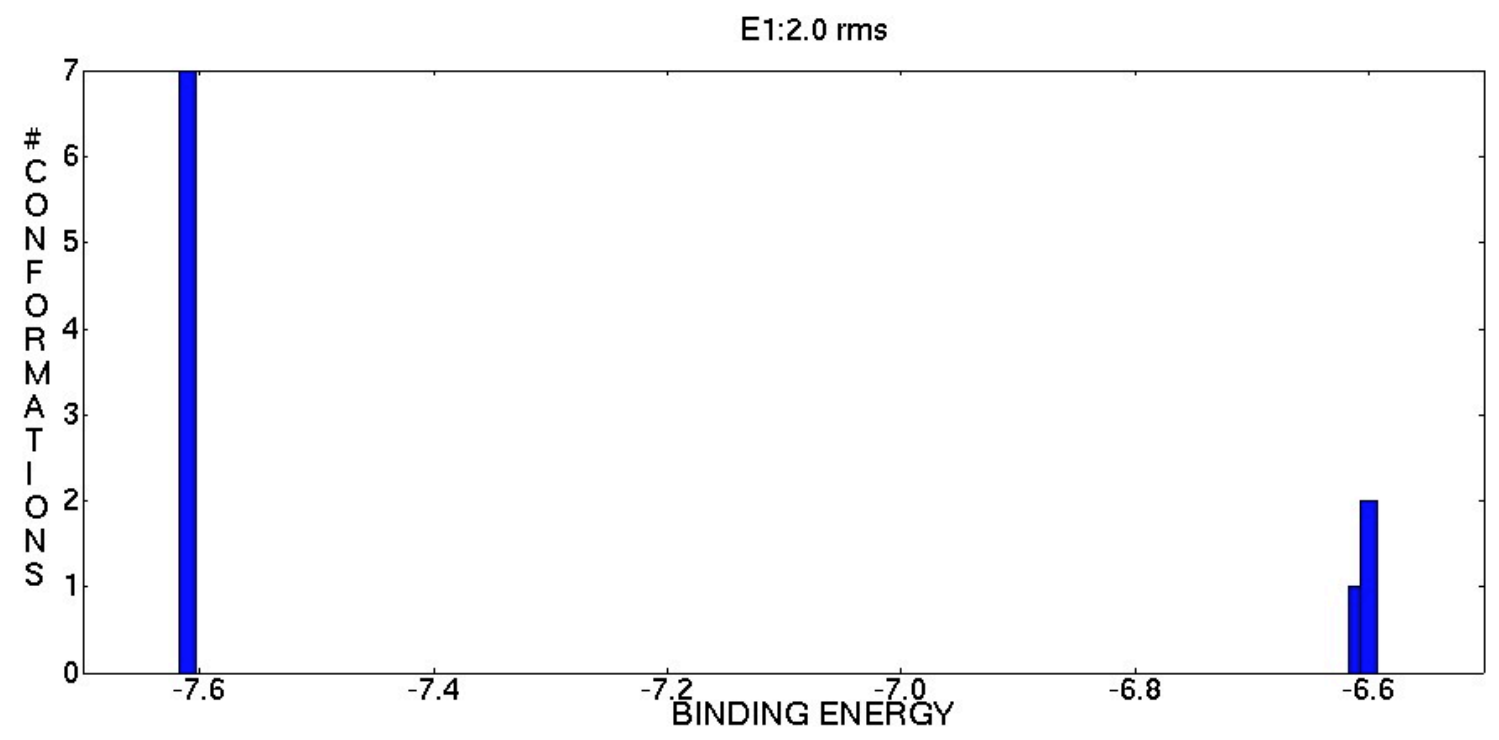

Figure 19. Estrone conformation clusters

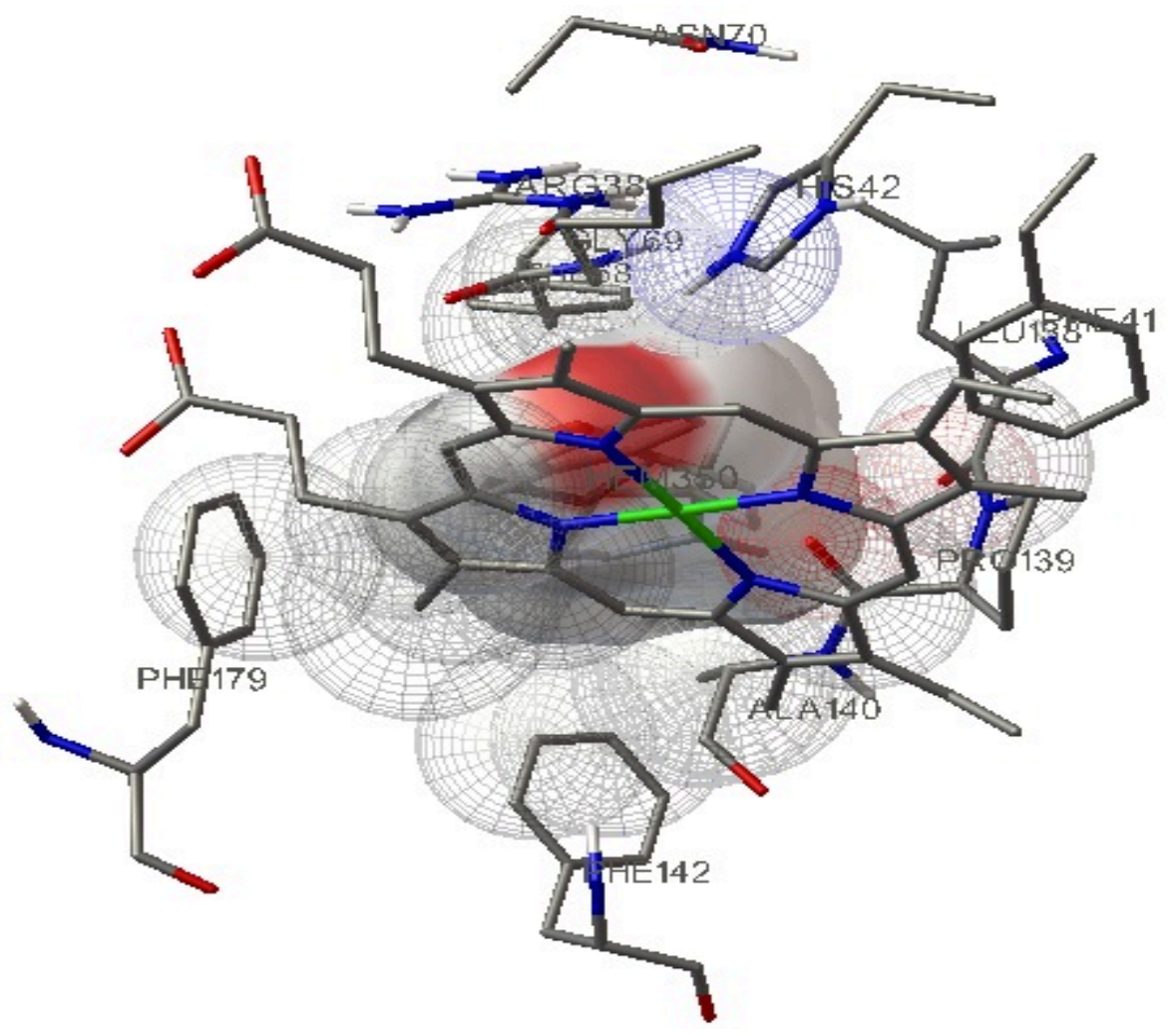

Figure 20. Interaction of estrone and relevent enzyme residues. 
Table 22. Estradiol binding conformations and energies

\begin{tabular}{|c|c|c|c|}
\hline Binding properties & Unit $(\mathrm{kcal} / \mathrm{mol})$ & Unit $(\mathrm{kcal} / \mathrm{mol})$ & Unit $(\mathrm{kcal} / \mathrm{mol})$ \\
\hline binding energy & -8.01 & -7.83 & -7.81 \\
\hline Ligand efficiency & -0.4 & -0.39 & -0.39 \\
\hline Inhibition constant & $1.35 \mu \mathrm{M}$ & $1.82 \mu \mathrm{M}$ & $1.89 \mu \mathrm{MM}$ \\
\hline Intermol energy & -8.6 & -8.43 & -8.4 \\
\hline Vdw sesolvation energy & -8.55 & -8.39 & -8.39 \\
\hline Electrostatic energy & -0.05 & -0.04 & -0.01 \\
\hline Moving ligand fixed receptor & -8.6 & -8.43 & -8.4 \\
\hline Moving ligand moving receptor & -0.01 & -0.03 & -0.1 \\
\hline Total internal & 0.06 & 0.06 & 0.06 \\
\hline Ligand internal & 0.06 & 0.06 & 0.06 \\
\hline Torsional energy & 0.6 & 0.6 & 0.6 \\
\hline Unbound energy & 0.06 & 0.06 & 0.06 \\
\hline $\mathrm{Cl} \mathrm{RMS}$ & 0 & 0.72 & 0.69 \\
\hline Ref RMS & 4.63 & 4.43 & 4.68 \\
\hline
\end{tabular}


10 lowest energy conformations in total and figures fall into the same cluster have very similar binding site.

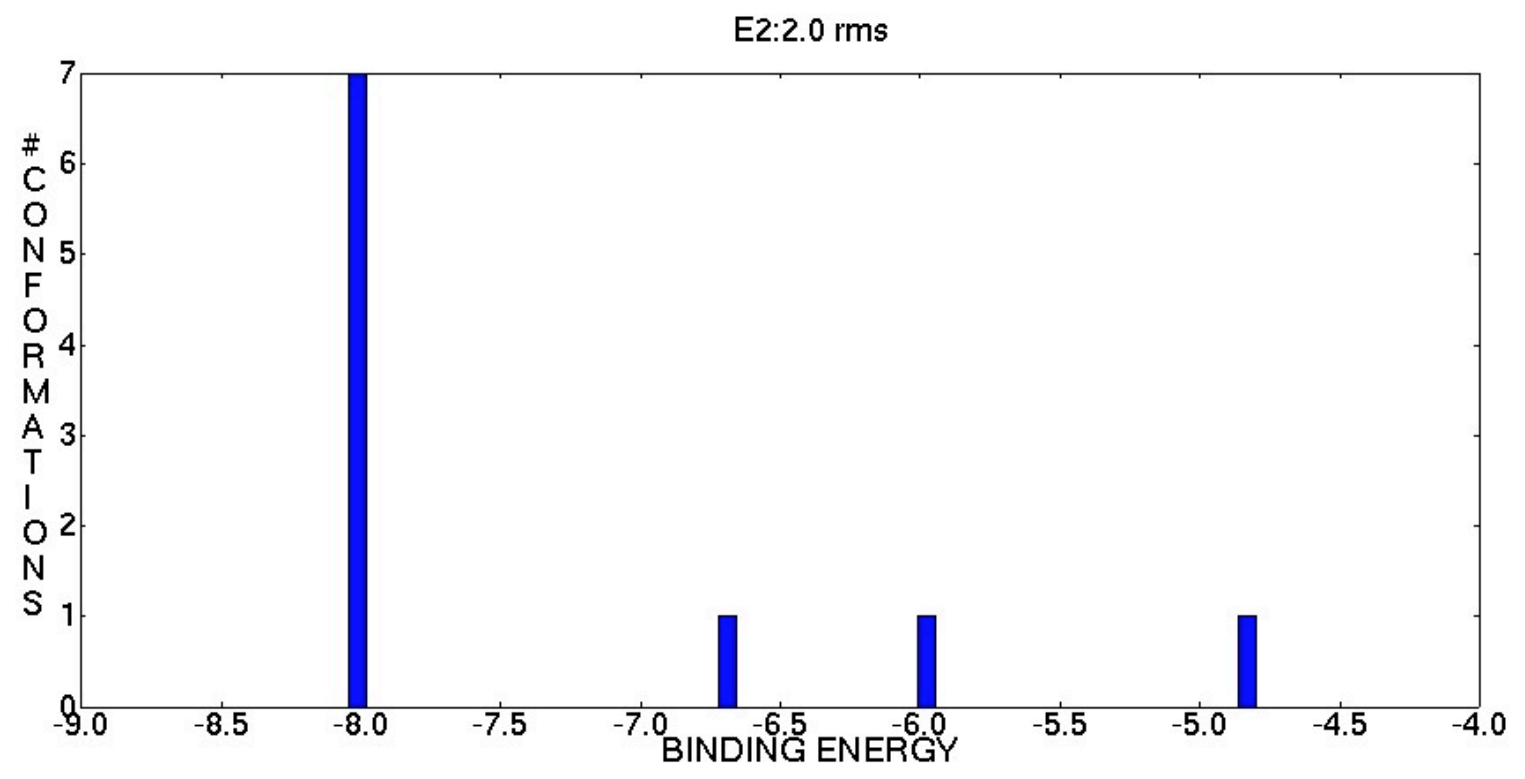

Figure 21. Estradiol conformation clusters

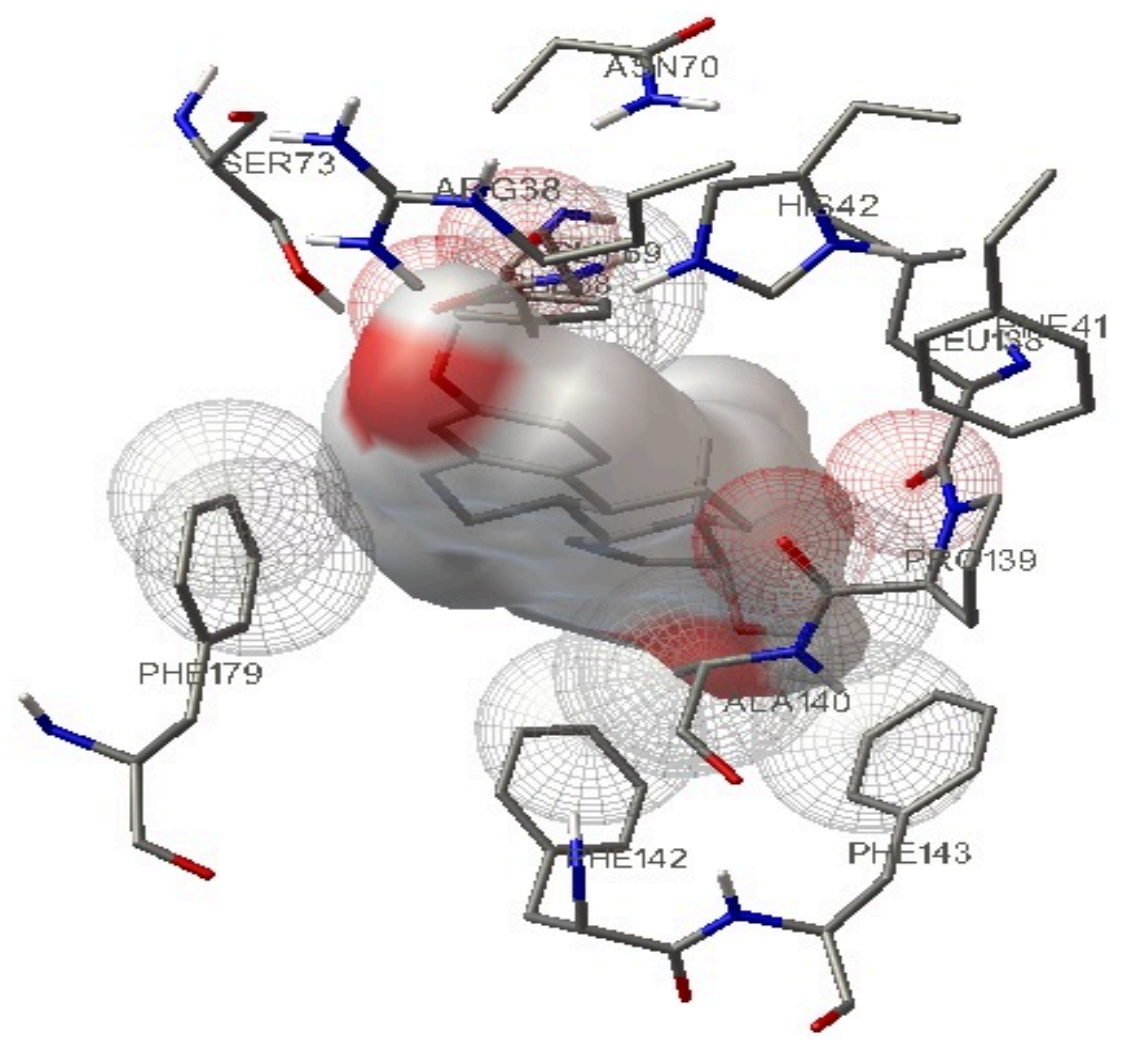

Figure 22. Interaction of estradiol and relevent enzyme residues. 
Table 23. Estriol binding conformations and energies

\begin{tabular}{|c|c|c|c|}
\hline Binding property & Unit & Unit & Unit \\
\hline & $(\mathrm{kcal} / \mathrm{mol})$ & $(\mathrm{kcal} / \mathrm{mol})$ & $(\mathrm{kcal} / \mathrm{mol})$ \\
\hline binding energy & -7.36 & -7.3 & -7.29 \\
\hline Ligand efficiency & -0.35 & -0.35 & -0.35 \\
\hline Inhibition constant & $4.03 \mu \mathrm{MM}$ & $4.46 \mu \mathrm{MM}$ & $4.53 \mu \mathrm{MM}$ \\
\hline Intermol energy & -8.25 & -8.19 & -8.19 \\
\hline Vdw sesolvation energy & -8.25 & -8.19 & -8.17 \\
\hline Electrostatic energy & -0.0 & -0.0 & -0.02 \\
\hline Moving ligand fixed receptor & -8.25 & -8.19 & -8.19 \\
\hline Moving ligand moving receptor & -1.2 & -0.52 & -0.35 \\
\hline Total internal & 0.21 & 0.12 & 0.03 \\
\hline Ligand internal & 0.21 & 0.12 & 0.03 \\
\hline Torsional energy & 0.89 & 0.89 & 0.89 \\
\hline Unbound energy & 0.21 & 0.12 & 0.03 \\
\hline Cl RMS & 0 & 0.58 & 0.46 \\
\hline Ref RMS & 4.77 & 4.5 & 4.92 \\
\hline
\end{tabular}


10 lowest energy conformations in total and figures fall into the same cluster have very similar binding site.

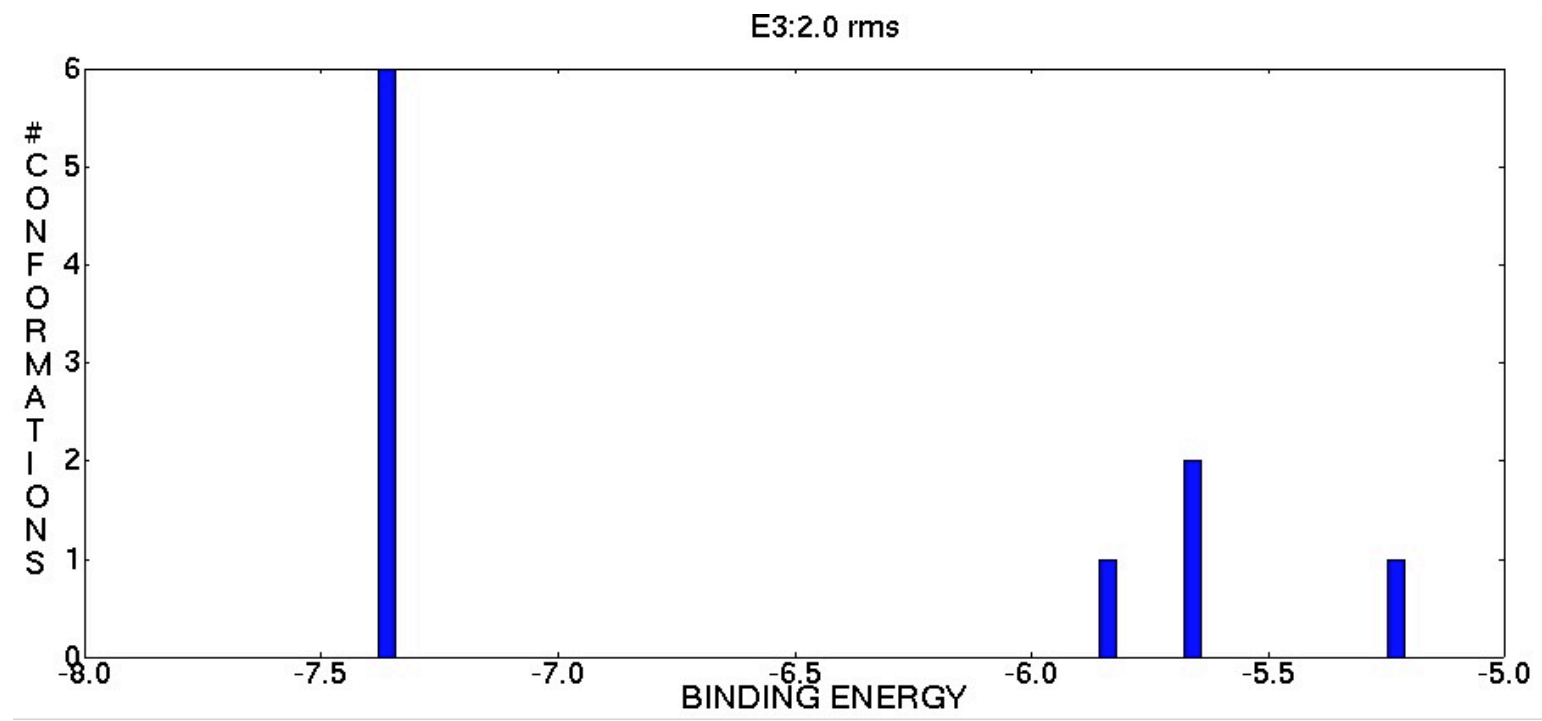

Figure 23. Estriol conformation clusters

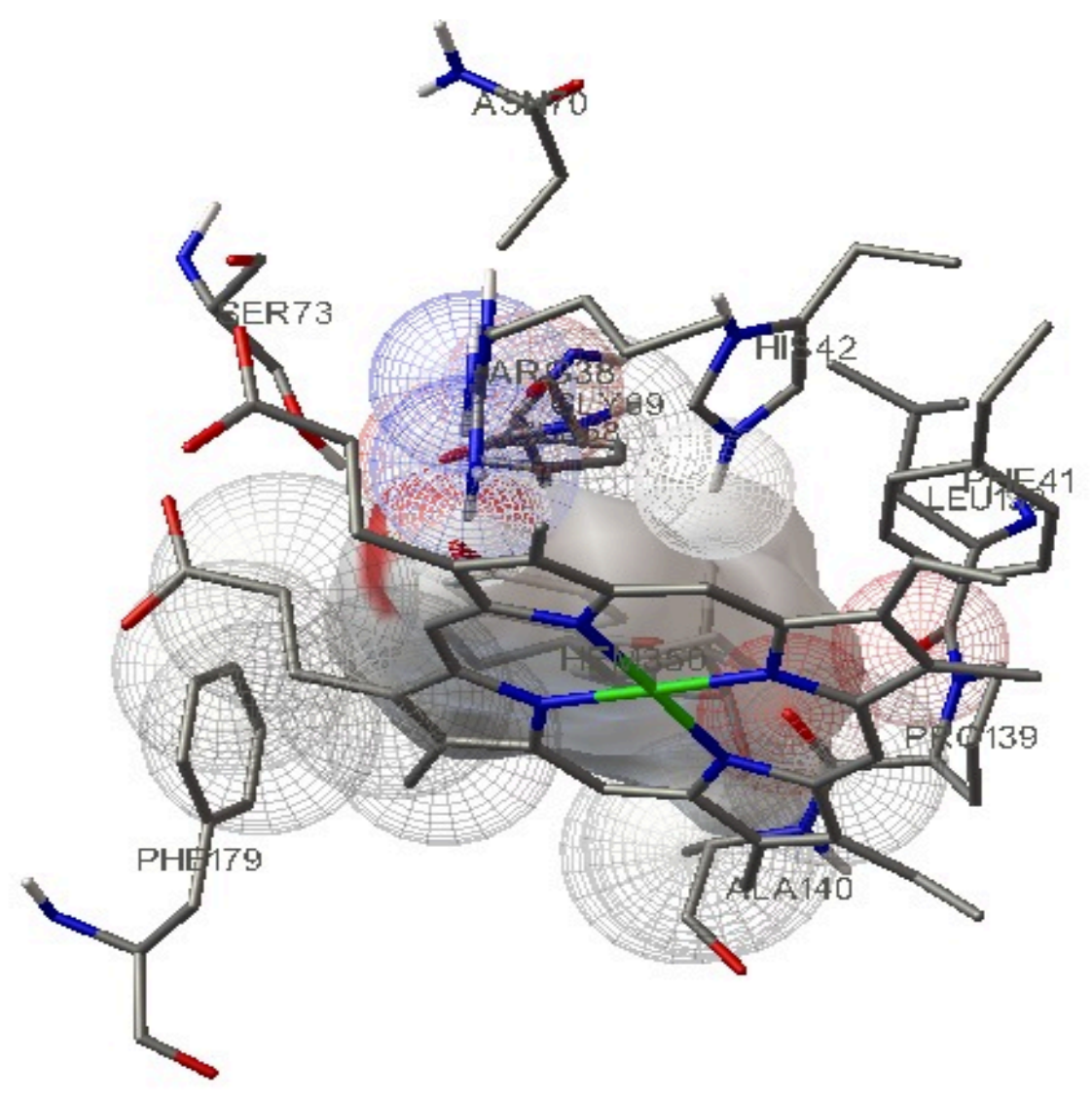

Figure 24. Interaction of estriol and relevent enzyme residues 
Table 24. 17 $\alpha$-ethinylestradiol binding Conformations and Energies

\begin{tabular}{|c|c|c|c|}
\hline Binding properties & Unit & Unit & Unit \\
\hline & $(\mathrm{kcal} / \mathrm{mol})$ & $(\mathrm{kcal} / \mathrm{mol})$ & $(\mathrm{kcal} / \mathrm{mol})$ \\
\hline binding energy & -7.66 & -7.65 & -7.25 \\
\hline Ligand efficiency & -0.35 & -0.35 & -0.33 \\
\hline Inhibition constant & 2.42 & 2.48 & 4.86 \\
\hline Intermol energy & -8.26 & -8.24 & -7.85 \\
\hline Vdw sesolvation energy & -8.19 & -8.17 & -7.89 \\
\hline Electrostatic energy & -0.07 & -0.07 & 0.04 \\
\hline Moving ligand fixed receptor & -8.26 & -8.24 & -7.85 \\
\hline Moving ligand moving receptor & -0.07 & -0.06 & -0.05 \\
\hline Total internal & 0.5 & 0.15 & 0.06 \\
\hline Ligand internal & 0.5 & 0.15 & 0.06 \\
\hline Torsional energy & 0.6 & 0.6 & 0.6 \\
\hline Unbound energy & 0.5 & 0.15 & 0.06 \\
\hline Cl RMS & 0 & 0.12 & 0.79 \\
\hline Ref RMS & 4.48 & 4.45 & 4.31 \\
\hline
\end{tabular}


10 lowest energy conformations in total and figures fall into the same cluster have very similar binding site.

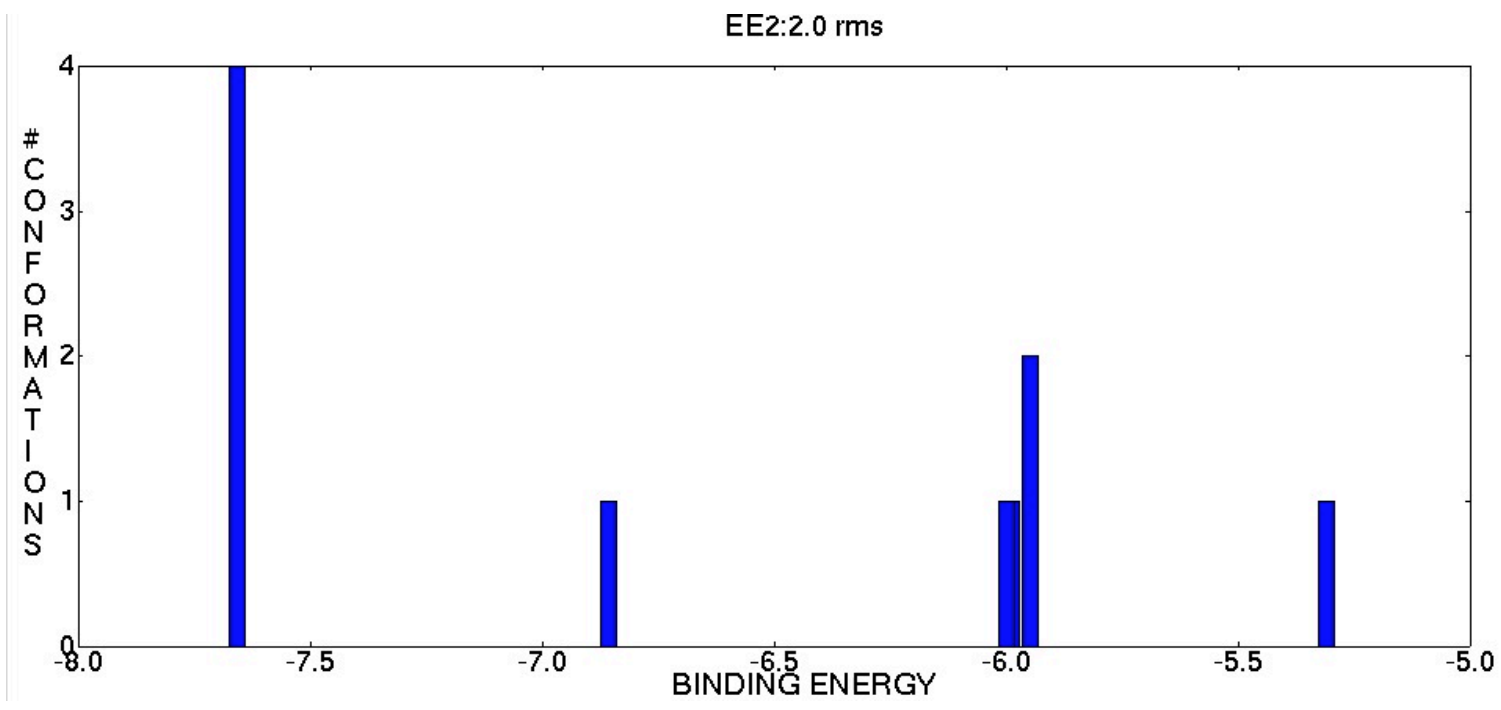

Figure 25. 17a-ethinylestradiol conformation clusters

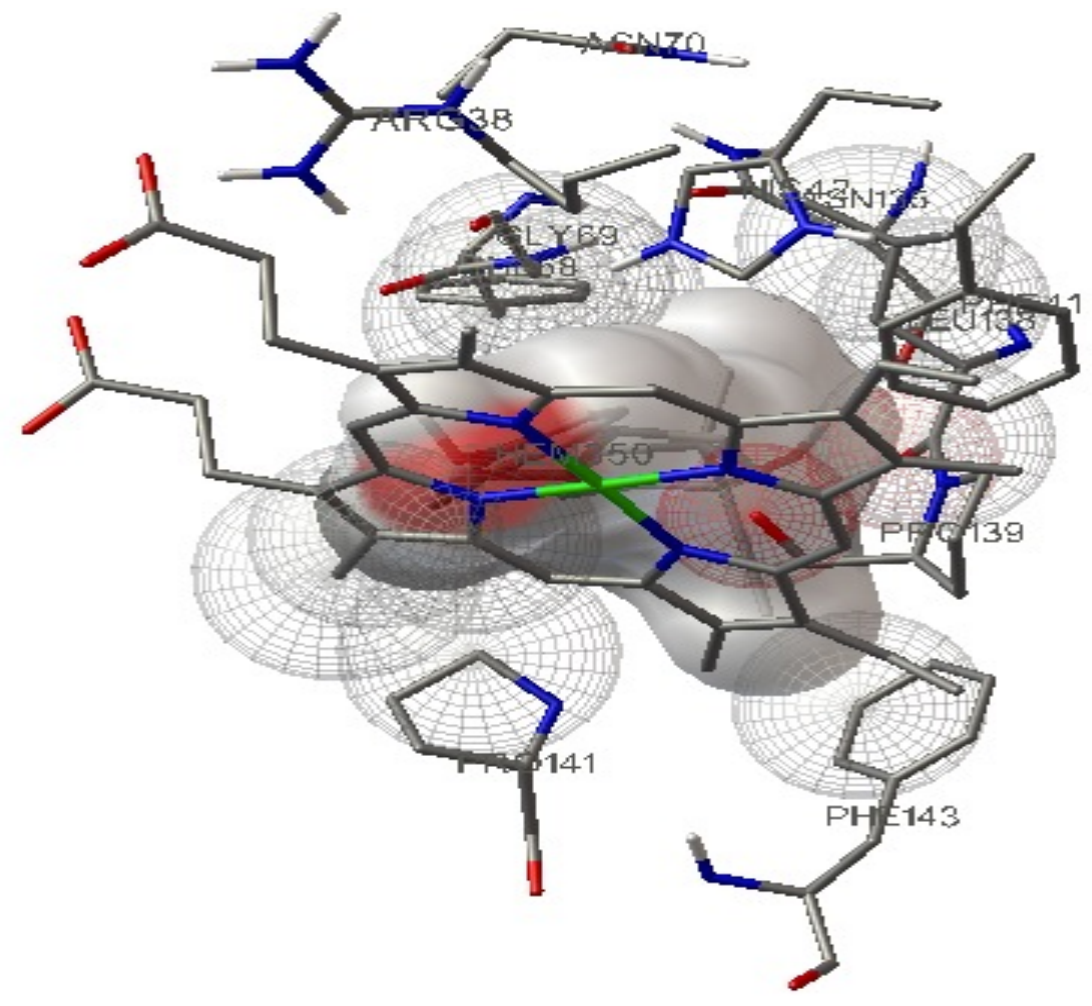

Figure 26. Interaction of $17 \alpha$-ethinylestradiol and relevent enzyme residues. 


\section{BIBLIOGRAPHY}

Aerni, H.-R., Kobler, B., Rutishauser, B.V., Wettstein, F.E., Fischer, R., Giger, W., Hungerbuhler, A., Marazuela, M.D., Peter, A., Schonenberger, R., Vogeli, A.C., Suter, M.J.-F., Eggen, R.I.L., 2004. Combined biological and chemical assessment of estrogenic activities in wastewater treatment plant effluents. Analytical and Bioanalytical Chemistry. 378 (3), 688-696.

Alum, A., Yoon, Y., Westerhoff, P., Abbaszadegan, M. 2004. Oxidation of BPA, E2, EE2 and byproduct estrogenicity. Environmental Toxicity. 19 (3), 257-264.

Andersen, H., Hansen, M., Kjølholt, J., Stuer-Lauridsen, F., Ternes, T., Halling-Sørensen, B., 2005. Assessment of the importance of sorption for steroid estrogens removal during activated sludge treatment. Chemosphere. 61 (1), 139-146.

Auriol, M., Filali-Meknassi, Y., Adams, C.D., Tyagi, R.D., 2006b. Natural and synthetic hormone removal using the horseradish peroxidase enzyme: temperature and $\mathrm{pH}$ effects. Water Research. 40 (15), 2847-2856.

Auriol, M., Filali-Meknassi, Y., Tyagi, R.D., Adams, C.D. 2007.Oxidation of natural and synthetic hormones by the horseradish peroxidase enzyme in wastewater. Chemosphere. 68 (10), 1830-1837.

Auriol, M., Filali-Meknassi, Y., Adams, C. D., Tyagi, R. D., Noguerol, T. N., Pina, B. 2008. Removal of estrogenic activity of natural and synthetic hormones from a municipal wastewater: Efficiency of horseradish peroxidase and laccase from Trametes versicolor. Chemosphere. 70 (3), 445-452.

Baronti, C., Curini, R., D’ Assenzo, G., Di Corcia, A., Gentili, A., Samprti, R., 2000. Monitoring natural and synthetic estrogens at activated sludge sewage treatment plants and in a receiving river water. Environmental Science \& Technology. 34 (24), 5059-5065.

Blanch and Clark. 1997. Biochemical Engineering. Marcel Dekker Publishers, New York, NY. 702.

Belfroid, A.C., Van der Horst, A., Vethaak, A.D., Schafer, A.J., Rijis, G.B.J., Wegener, J., Cofino, W.P. 1999. Analysis and occurrence of estrogenic hormones and their glucuronides in surface water and wastewater in the Netherlands. Science of Total Environment. 225 (1-2), 101108.

Benotti, M.J., Trenholm, R.A., Vanderford, B.J., Holady, J.C., Stanford, B.D., Synder, S.A. 2009. Pharmaceuticals and endocrine disrupting compounds in US drinking water. Environmental Science \& Technology. 43 (3), 597-603. 
Bordeleau, L.M., Bartha, R. 1972. B iochemical transformations of herbicide-derived anilines: requirements of molecular configuration. Canadian Journal of Microbiology. 18 (12), 1873-1882.

Boyd, G. R., Reemtsma, H., Grimm, D. A., Mitra, S., 2003. Pharmaceuticals and personal care products (PPCPs) in surface and treated waters of Louisiana, USA, and Ontario, Canada. Science of Total Environment. 311 (1-3), 135-149.

Brewster, M.E., Doerge, D.R., Huang, M.J., Kaminski, J.J., Pop, E., Bodor, N., 1991. Application of semiempirical molecular orbital techniques to the study of peroxidase-mediated oxidation of phenols, anilines, sulfides and thiobenzamides. Tetrahedron, 47 (36), 7525-7536.

Burkholder, J., Libra, B., Weyer, P., Heathcote, S., Kolpin, D., Thorne, P.S., Wichman, M., 2007. Impacts of waste fron concentrated animal feeding operations on water quality. Environmental Health Perspective. 115 (2), 308-312.

Cabana, H., Jiwan, J. H., Rozenberg, R., Elisashvili, V., Penninckx, M., Agathos, S.N., Jones, J. P. 2007. Elimination of endocrine disrupting chemicals nonylphenol and bisphenol A and personal care product ingredient triclosan using enzyme preparation from the white rot fungus Coriolopsis polyzona. Chemosphere. 67(4). 770-778.

Casey, F. X. M., Larsen, G. L., Hakk, H., Simunek, J. 2003. Fate and transport of 17ß-estradiol in soil-water system. Environmental Science \& Technology. 37 (11), 2400-2409.

Chang, C. S., Yamazaki, I., Sinclair, R., Khalid, S., Powers, L. 1993. PH dependence of the active site of horseradish peroxidase compound II. Biochemistry. 32 (3), 923-928.

Clara, M., Strenn, B., Saracevic, E., Kreuzinger, N., 2004. Adsorption of bisphenol A, 17ßestradiole and 17 $\alpha$-ethinylestradiole to sewage sludge. Chemosphere. 56 (9), 843-851.

Colosi, M.L., Huang, Q., Weber, W.J., 2006. Quantitative structure-activity relationship based quantification of the impacts of enzyme-substrate binding on rates of peroxidase-mediated reactions of estrogenic phenolic chemicals. Journal of the American Chemistry Society, 128 (12), 4041-4047.

Colosi, M.L., Huang, Q., Weber, W.J. 2010. QSAR-assisted design of an environmental catalyst for enhanced estrogen remediation. Chemosphere, 81 (7), 897-903.

Cornish-Bowden, A. 2002. Enthalpy-entropy compensation: a phantom phenomenon. Journal of Biosciences. 27 (2), 127-126.

Dunford, H.B., 1999. Heme peroxidases. Wiley-VCH, New York.

Dunford, H.B., 1991. H orseradish peroxidase: Structure and kinetic properties. In: Everse, J., Everse, K.E., Grisham, M.B. (Eds.), Peroxidases in chemistry and biology, Vol. 2. CRC Press, Boca Raton, Florida, 1-24. 
Filali-Meknassi, Y., Auriol, M., Adams, C.D., Surampalli, R.Y. 2007. Quantification of steroid sex hormones using solid-phase extraction followed by liquid chromatography-mass spectrometry. Water Environmental Research. 79 (6), 687-696.

Frank, H.S., and Evans, M.W. 1945. Free volume and entropy in condensed systems.III. Entropy in binary liquid mixtures; partial molal entropy in dilute solution; structure and thermodynamics in aqueous electrolytes", The Journal of Chemical Physics, 13 (11), 507-532.

Fukuhara, T., Iwasaki, S., Kawashima, M., Shinohara, O., Abe, I. 2006. Adsorbability of estrone and 17ß-estradiol in water onto activated carbon. Water Research. 40(2), 241-248.

Gilabert, M.A., Hiner, A.N.P., Garcia-Ruiz, P.A., Tudela, J., Garcia-Molina, F., Acosta, M., Garcia-Canovas, F., Rodriguez-Lopez, J.N. 2004. Differential substrate behaviour of phenol and aniline derivatives during oxidation by horseradish peroxidase: kinetic evidence for a two-step mechanism. Biochimica et Biophysica Acta. 1699 (1-2), 235-243.

Gutendorf, B., Westendorf, J. 2001. Comparison of an array of in vitro assays for the assessment of the estrogenic potential of natural and synthetic estrogens, phytoestrogens and xenoes-trogens. Toxicology. 166 (1\&2), 79-89.

Hanselman, T.A., Graetz, D.A., Wilkie, A.C. 2003. M anure-borne estrogens as potential environmental contaminants: a review. Environmental Science \& Technology. 37 (24), 54715478 .

Hogan, N. S., Lean, D. R., Trudeau, V. L. 2006. Exposures to estradiol, ethinylestradiol and octylphenol affect survival and growth of Rana pipiens and Rana sylvatica tadpoles. Journal of Toxicology and Environmental Health. Toxicol. Environ.Health, Part A, 69 (16), 1555-1569.

Hosoya, T., Fujii, T., Ogawa, S. 1983. A molecular orbital study on the oxidation of hydrogen donor molecules by peroxidase compound II. Journal of Theoretical Biology, 100 (2), 283-292.

Huang, Q. and Weber, W. J. 2005. Transformation and removal of bisphenol A from aqueous phase via peroxidase-mediated oxidative coupling reactions: efficacy, products, and pathways. Environmental Science \& Technology. 39 (16), 6029-6036.

Huang, Q., Tang, J., Weber, W. J. 2005. P recipitation of enzyme-catalyzed phenol oxidative coupling products: Background ion and pH effects. Water Research, 39 (13), 3021-3027.

Ikehata, K., El-Din, M.G., Snyder, S.A. 2008. Ozonation and advanced oxidation treatment of emerging organic Pollutants in water and wastewater. Ozone: Science and Engineering. 30 (1), 21-26.

Iwanowicz, L. R., Blazer, V. S., Guy, C. P., Pinkney, A. E., Mullican, J. E., Alvarez, D. A. 2009. Reproductive health of bass in the Potomac, USA, Drainage Part 1: Exploring the effects of proximity to wastewater treatment plant discharge. Environmental Toxicology \& Chemistry. 28 (5), 1072-1083. 
Janssen, A.E.M., Sjursnes, B.J., Vakurov, A.V., Hall, P.J. 1999. Kinetics of lipase-catalyzed esterification in organic media: Correct model and solvent effects on parameters. Enzyme and Microbial Technology, 24 (8-9), 463-470.

Job, D., Dunford, H.B. 1976. Substituent effect on the oxidation of phenols and aromatic amines by horseradish peroxidase compound I. European Journal of Biochemistry, 66, 607-614.

Jobling, S., Williams, R., Johnson, A., Taylor, A., Gross-Sorokin, M., Nolan, M., Tyler, C. R., van Aerle, R., Santos, E., Brighty,G. 2006. P redicted exposures to steroid estrogens in U.K. rivers correlate with widespread sexual disruption in wild fish populations. Environmental Health Perspective. 114 (1), 32-39.

Johnson, A. C., Belfroid, A., Corcia, A.D., 2000. Estimating steroid estrogen inputs into activated sludge streatment works and observations on their removal from the effluent. Science of The Total Environment. 56 (2-3), 163-173.

Johnson, A. C., Sumpter, J. P. 2001. R emoval of endocrine-disrupting chemicals in activated sludge treatment works. Environmental Science \& Technology. 35 (24), 4697-4703.

Kamerlin, S., Florian, J., Warshel, A. 2008. A ssociative versus dissociative mechanisms of phosphate monoester hydrolysis: On the interpretation of activation entropies. ChemPhyChem, 9(12), 1767-1773.

Kathy, J.B., Jatinder, K.B., Nihar Biswas, K.E.T. 1994. Inactivation of horseracish peroxidase by phenol and hydrogen peroxide: a kinetic investigation. Biochimica et Biophysica Acta- Protein Structure and Molecular Enzymology. 1206 (2), 272-278.

Kim, J.Y., Chang, I.S., Park, H.H., Kim, C.Y., Kim, J.B., Oh, J.H. 2008. New configuration of A membrane bioreactor for effective control of membrane fouling and nutrients removal in wastewater treatment. Desalination. 230 (1-3), 153-161.

Kinoshita, M. 2009. Roles of translational motion of water molecules in sustaining life. Frontiers in Bioscience-Landmark, 14, 3419-3448.

Kinsley, C., Nicell, J.A. 2000. Treatment of aqueous phenol with soybean peroxidase in the presence of polyethylene glycol. Bioresource Technology. 73 (2), 139-146.

Klibanov, A.M., Tu, T., Scott, K.P. 1983. Peroxidase-catalyzed removal of phenols from coalconversion waste waters. Science. 221 (4807), 259-267.

Kocherbitov. V., Arnebrant, T. 2010. Hydration of Lysozyme: The Protein-Protein Interface and the Enthalpy-Entropy Compensation. Langmuir, 26(6), 3918-3922.

Kolodziej, E.P., Harter, T., Sedlak, D.L. 2004. Dairy Wastewater, aquaculture, and spawning fish as sources of steroid hormones in the aquatic environment. Environmental Science \& Technology. 38 (23), 6377-6384. 
Kuch, H. M., Ballschmiter, K. 2001. Determination of endocrine-disrupting phenolic compounds and estrogens in surface and drinking water by HRGC-(NCI)-MS in the picogram per liter range. Environmental Science \& Technol. 35 (15), 3201-3206.

Lai, K.M., Johnson, K.K., Scrimshaw, M.D., Lester, J.N. 2000. B inding of waterborne steroid estrogens to solid phases in river and estuarine systems. Environmental Science \& Technololy. 34 (18), 3890-3894.

Lai, K.M., Scrimshaw, M.D., Lester, J.N. 2000. Prediction of the bioaccumulation factors and body burden of natural and synthetic estrogens in aquatic organisms in the river systems. Science of Total Environment, 289, 159-168.

Lange, I.G., Daxenberger, A., Schiffer, B., Witters, H., Ibarreta, D., Meyer, H.H.D. 2002. S ex hormones originating from different livestock production systems: fate and potential disrupting activity in the environment. Analytica Chimica Acta. 473, 27-37.

Leusch, F.D.L., Chapman, H.F., Korner, W., Gooneratne, S.R., and Tremblay, L.A. 2005. Efficacy of an advanced sewage treatment plant in southeast queensland, australia, to remove estrogenic chemicals. Environmental Science \& Technology. 39, 5781-5786.

Liu, B., Liu, X. 2004. Direct photolysis of estrogens in aqueous solutions. Science of Total Environment. 320 (2-3), 269-274.

Liu, R., Wilding, A., Hibberd, A., Zhou, J. L. 2005. Partition of endocrine-disrupting chemicals between colloids and dissolved phase as determined by cross-flow ultrafiltration. Environmental Science \& Technology. 19 (8), 2753-2761.

Lumry, R., Rajender, S. 1970. Enthalpy-entropy compensation phenomena in water solutions of proteins and small molecules: a ubiquitous property of water. Biopolymers. 9 (10), 1125-1227.

Milischuk, A., Matyushov, D., Newton, M. 2006. A ctivation entropy in electron transfer reactions. Chemical Physics, 324, 172-194.

Moriyama, K., Matsufuji, H., Chino, M., Takeda, M. 2004. Identification and behavior of reaction products formed by chlorination of ethynylestradiol. Chemosphere. 55 (6), 839-847.

Nakajima, R.; Yamazaki, I. 1987. T he mechanism of oxyperoxidase formation from ferryl peroxidase and hydrogen peroxide. Journal of Biological Chemistry. 262, 2576-2581.

Nakamoto, S., Machida, N. 1992.Phenol removal from aqueous solutions by peroxidasecatalyzed reaction using additives. Water Research. 26 (1), 49-54.

National Agricultural Statistics Service. 2001. United States Department of Agriculture.

Purdom, C. E., Hardiman, P. A., Bye, V. J., Eno, N. C., Tyler, C. R., Sumpter, J. P. 1994. Estrogenic effects of effluents from sewage treatment works. Journal of Chemical Ecology, 8, 275-285. 
Sakurada, J., Sekiguchi, R., Sato, K., Hosoya, T. 1990. Kinetic and molecular orbital studies on the rate of oxidation of monosubstituted phenols and anilines by horseradish peroxidase compound II. Biochemistry, 29 (17), 4093-4098.

Sakurai, A., Toyoda, S., Sakakibara, M., 2001.Removal of bisphenol A by polymerization and precipitation method using Coprinuscinereus peroxidase. Biotechnology Letters. 23 (12), 995998.

Sanner M.F., 1999. P ython: A Programming Language for Software Integration and Development. Journal of Molecular Graphics and Modeling. 17, 57-61.

Sanner M.F., Stoffler, D., Olson, A.J., 2002. ViPEr a Visual Programming Environment for Python. 10th International Python Conference.

Stearn, A., Johnston, H., Clark, C. 1939. The significance of activation entropy in catalytic mechanisms. Journal of Chemical Physics, 7, 970-971.

Snyder, S.A., Adham, S., Redding, A.M., Cannon, F.S., DeCarolis, J., Oppenheimer, J., Wert, E.C., Yoon, Y. 2007. R ole of membranes and activated carbon in the removal of endocrine disruptors and pharmaceuticals. Desalination. 202 (1-3), 156-181.

Ternes, T. A., Kreckel, P., Mueller. 1999. Behavior and occurrence of estrogens in municipal sewage treatment plants - II. Aerobic batch experiments with activated sludge. Journal of the Total Environment. 225(1-2), 91-99.

Ternes, T., Herrmann, N., Bonerz, M., Knacker, T., Siegrist, H., Joss, A. 2004. A rapid method to measure the solid-water distribution coefficient $(\mathrm{kd})$ for pharmaceuticals and musk fragrances in sewage sludge. Water Research. 38 (19), 4075-4084.

Tyler, C.R., Spary, C., Gibson, R., Santos, E.M., Shears, J., Hill, E. M. 2005. Accounting for differences in estrogenic responses in rainbow trout and rouch exposed to effluents from wastewater treatment works. Environmental Science \& Technology. 39, 2599-2607.

US Environmental Protection Agency (USEPA). 2003. Endocrine Disruptors Research Initiative. /http://www.epa.gov/endocrine/ S (May 5, 2004).

Vader, J.S., Finkel, C.G., Sperling, F.M.G.M., Jong, J., Boer, W., Graaf, J.S., Most, M., Stokman, P.G.W. 2000. Degradation of ethinyl estradiol by nitrifying activated sludge. Chemosphere. 41 (8), 1239-1243.

Van de Velde, F., Rantwijk, F.R., Sheldon, R.A. 2001. Improving the catalytic performance of peroxidases in organic synthesis. Trends in Biotechnology, 19 (2), 73-80.

Veitch, N.C., Smith, A.T. 2001. Horseradish peroxidase. Advanced Inorganic Chemistry. 51, 107-162. 
Velicu, M., Suri, R. 2009. Presence of steroid hormones and antibiotics in surface water of agricultural, suburban and mixed-use areas. Environmental Monitoring and Assessment. 154 (14), 349-359.

Villa, J., Strajbl, M., Glennon, T., Sham, Y., Chu, Z., Warshel, A. 2000. How important are entropic contributions to enzyme catalysis? Proceedings of the National Academy of Sciences, 97(22), 11899-11904.

Vlasits, J., Bellei, M., Jakopitsch, C., Rienzo, F.D., Furtmller, P.G., Zamocky, M., Sola, M., Battistuzzi, G., Obinger, C. 2010. Disruption of the H-bond network in the main access channel of catalase-peroxidase modulates enthalpy and entropy of Fe (III) reduction. Journal of Inorganic Biochemistry. 104, 648-656.

Wagner, M., Nicell, J.A. 2002.Detoxification of phenolic solutions with horseradish peroxidase and hydrogen peroxide. Water Research. 36 (16), 4041-4052.

Westerhoff, P., Yoon, Y., Snyder, S., Wert, E. 2005. Fate of endocrine-Disruptor, pharmaceutical, and personal care product chemicals during simulated drinking water treatment processes. Environmental Science \& Technology. 39 (17), 6649-6663.

Williams, R.J., Johnson, A.C., Smith, J.J.L., Kanda, R. 2003. Steroid estrogens profiles along river stretches arising from sewage treatment works discharges. Environmental Science \& Technology. 37 (9), 1744-1750.

Wintgens, T., Gallenkemper, M., Melin, T. 2002. Endocrine disrupting removal from wastewater using membrane bioreactor and nanofiltration technology. Desalination. 146 (1-3), 387-391.

Wu, J.N., Taylor, K.E., Bewtra, J.K., Biswas, N. 1993. Optimization of the reaction conditions for enzymatic removal of phenol from wastewater in the presence of polyethylene glycol. Water Research. 27 (12), 1701-1706.

Wu, Y.M., Taylor, K.E., Biswas, N., Bewtra, J.K. 1998. Enzyme and Microbial Technology. 22 (5). 315-322.

Yi, T., Harper, W.F. 2007. The effect of biomass characteristics on the partitioning and sorption hysteresis of 17 a -ethinyleestradiol. Water Research. 41 (7), 1543-1553.

Yu, J., Taylor, K.E., Zou, H.X., Biswas, N., Bewtra, J.K. 1994. Phenol conversion and dimetic intermediates in the horseradish peroxidase-catalyzed phenol removal from water. Environmental Science \& Technology, 28 (12), 2154-2160.

Zheng, W., Colosi, L.M., 2011. Peroxidase-mediated removal of endocrine disrupting compound mixtures from water. Chemosphere, in press. 